\title{
Unlocking Structural Diversity in Gold(III) Hydrides: Unexpected Interplay of cis/trans-Influence on Stability, Insertion Chemistry, and NMR Chemical Shifts
}

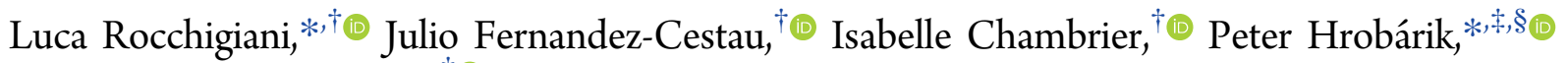 \\ and Manfred Bochmann* ${ }^{*} \dagger$ \\ ${ }^{\dagger}$ School of Chemistry, University of East Anglia, Norwich Research Park, NR4 7TJ Norwich, United Kingdom \\ ${ }^{\ddagger}$ Institut für Chemie, Technische Universität Berlin, Straße des 17. Juni 135, D-10623 Berlin, Germany \\ ${ }^{\S}$ Department of Inorganic Chemistry, Faculty of Natural Sciences, Comenius University, SK-84215 Bratislava, Slovakia
}

\section{Supporting Information}

ABSTRACT: The synthesis of new families of stable or at least spectroscopically observable gold(III) hydride complexes is reported, including anionic cis-hydrido chloride, hydrido aryl, and cis-dihydride complexes. Reactions between $\left(\mathrm{C}^{\wedge} \mathrm{C}\right) \mathrm{AuCl}-$ $\left(\mathrm{PR}_{3}\right)$ and $\mathrm{LiHBEt}_{3}$ afford the first examples of gold(III) phosphino hydrides $\left(\mathrm{C}^{\wedge} \mathrm{C}\right) \mathrm{AuH}\left(\mathrm{PR}_{3}\right)(\mathrm{R}=\mathrm{Me}, \mathrm{Ph}, p$-tolyl; $\mathrm{C}^{\wedge} \mathrm{C}=4,4^{\prime}$-di-tert-butylbiphenyl-2,2'-diyl). The X-ray structure of $\left(\mathrm{C}^{\wedge} \mathrm{C}\right) \mathrm{AuH}\left(\mathrm{PMe}_{3}\right)$ was determined. $\mathrm{LiHBEt}_{3}$ reacts with $\left(\mathrm{C}^{\wedge} \mathrm{C}\right) \mathrm{AuCl}(\mathrm{py})$ to give $\left[\left(\mathrm{C}^{\wedge} \mathrm{C}\right) \mathrm{Au}(\mathrm{H}) \mathrm{Cl}^{-}\right.$, whereas $\left(\mathrm{C}^{\wedge} \mathrm{C}\right)$ $\mathrm{AuH}\left(\mathrm{PR}_{3}\right)$ undergoes phosphine displacement, generating the dihydride $\left[\left(\mathrm{C}^{\wedge} \mathrm{C}\right) \mathrm{AuH}_{2}\right]^{-}$. Monohydrido complexes hydroaurate dimethylacetylene dicarboxylate to give $Z$-vinyls.

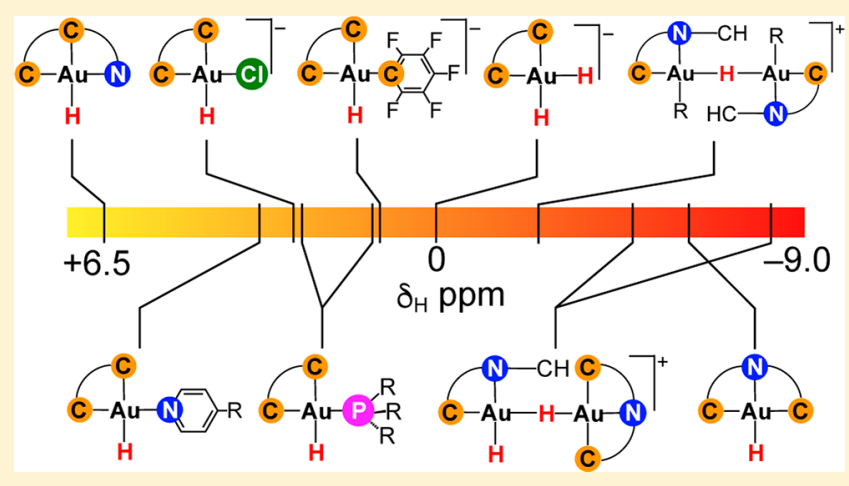
$\left(\mathrm{C}^{\wedge} \mathrm{N}^{\wedge} \mathrm{C}\right) \mathrm{Au}$ pincer complexes give the first examples of gold(III) bridging hydrides. Stability, reactivity and bonding characteristics of $\mathrm{Au}(\mathrm{III})-\mathrm{H}$ complexes crucially depend on the interplay between cis and trans-influence. Remarkably, these new gold(III) hydrides extend the range of observed NMR hydride shifts from $\delta-8.5$ to $+7 \mathrm{ppm}$. Relativistic DFT calculations show that the origin of this wide chemical shift variability as a function of the ligands depends on the different ordering and energy gap between "shielding" $\mathrm{Au}\left(\mathrm{d}_{\pi}\right)$-based orbitals and "deshielding" $\sigma(\mathrm{Au}-\mathrm{H})$-type MOs, which are mixed to some extent upon inclusion of spin-orbit (SO) coupling. The resulting ${ }^{1} \mathrm{H}$ hydride shifts correlate linearly with the DFT optimized $\mathrm{Au}-\mathrm{H}$ distances and $\mathrm{Au}-\mathrm{H}$ bond covalency. The effect of cis ligands follows a nearly inverse ordering to that of trans ligands. This study appears to be the first systematic delineation of cis ligand influence on $\mathrm{M}-\mathrm{H}$ NMR shifts and provides the experimental evidence for the dramatic change of the ${ }^{1} \mathrm{H}$ hydride shifts, including the sign change, upon mutual cis and trans ligand alternation.

\section{INTRODUCTION}

Transition metal hydrides are key components of many catalytic reactions and constitute one of the most important classes of coordination complexes. ${ }^{1}$ Hydrides of gold, ${ }^{2}$ by comparison, have been conspicuous by their absence and were long regarded as unstable or hypothetical. The first experimental evidence for their existence was reported by Andrews et al. in 2001, who generated binary hydrides such as $\mathrm{AuH},\left(\mathrm{H}_{2}\right) \mathrm{AuH},\left(\mathrm{H}_{2}\right) \mathrm{AuH}_{3}$, and $\left[\mathrm{AuH}_{4}\right]^{-}$in frozen gas matrices below $5 \mathrm{~K}^{3}$ The first example of an isolable gold(I) hydride was obtained in 2008, using an $N$-heterocyclic carbene (NHC) as stabilizing ligand. ${ }^{4}$ There are only two types of structurally characterized gold(III) hydrides known so far, both based on stabilization by $\mathrm{C}^{\wedge} \mathrm{N}^{\wedge} \mathrm{C}$ pincer ligands: $\left(\mathrm{C}^{\wedge} \mathrm{N}^{\wedge} \mathrm{C}\right) \mathrm{AuH}$ (Chart 1, structure A) first described in 2012, ${ }^{5,6}$ and Bezuidenhout's cation $\mathbf{B}$, generated by protonation of the corresponding $\mathrm{T}$-shaped $\mathrm{Au}(\mathrm{I})$ bis-carbene complex. ${ }^{7}$ In both cases the hydride ligands are trans to N- donors, which exert a weak trans-influence and thus increase the $\mathrm{Au}-\mathrm{H}$ bond enthalpy while reducing its reactivity. The thermally stable hydride A was subsequently detected in a number of catalysis-relevant reactions, notably the water-gas shift reaction., 8 Given that gold and hydrogen have very similar electronegativities, $\mathrm{Au}-\mathrm{H}$ bonds are highly covalent. The reactivity of gold(III) hydrides reflects this; whereas B can be deprotonated only by very strong bases, ${ }^{7}$ complexes of type A undergo homolytic $\mathrm{Au}-\mathrm{H}$ bond cleavage and insertion reactions with alkenes and alkynes via bimolecular pathways involving $\left(\mathrm{C}^{\wedge} \mathrm{N}^{\wedge} \mathrm{C}\right) \mathrm{Au}^{\mathrm{II}}$ radical intermediates. ${ }^{6,10}$

Gold hydrides have been postulated numerous times as part of catalytic cycles and a variety of coordination environments have been assumed, ${ }^{11-14}$ although experimental evidence for the structural diversity that is accessible to such species is as

Received: April 27, 2018

Published: June 4, 2018 
Chart 1. Structures of Previously Reported Gold(III) Hydrides A and B and of the Starting Materials 1-3<smiles></smiles>
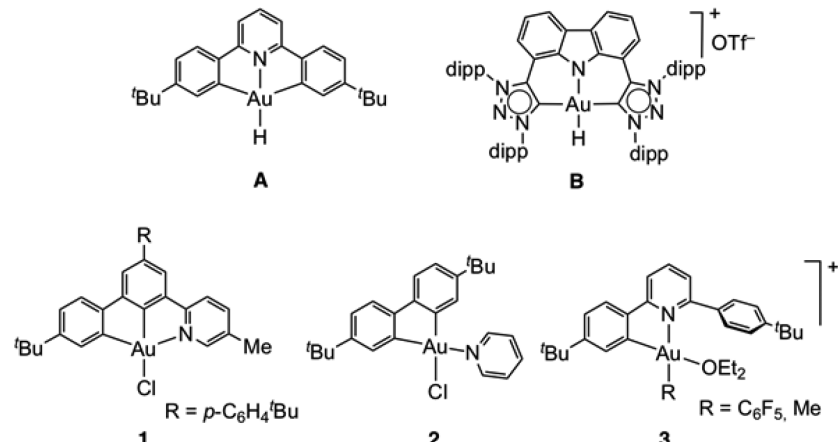

yet very limited. In square-planar $\mathrm{Au}(\mathrm{III})$ complexes the trans effect plays a fundamental role in determining chemical behavior, and the presence of strong electron-donating substituents trans to the hydride can dramatically increase the reactivity of the $\mathrm{Au}-\mathrm{H}$ bond. Some examples in the recent literature showed that trans-carbon donors facilitate $\beta$ hydride elimination from gold(III) alkyls or formate complexes. Highly reactive gold hydride intermediates were postulated, which can undergo insertion or reductive elimination processes. ${ }^{11,14}$ However, until now these types of $\mathrm{Au}(\mathrm{III})$ hydrides have not been directly observed.

For this reason, we designed an experimental study aimed at trapping new families of $\mathrm{Au}$ (III) hydrides featuring a Cdonor in the form of a cyclometalated aryl ligand in trans position, in order to investigate analogies and differences with the previously reported hydrides $\mathbf{A}$ and $\mathbf{B}$. To achieve this goal, we explored complexes with different types of ligand environments (Chart 1, compounds 1-3). First, we investigated the reactivity of the $\mathrm{C}^{\wedge} \mathrm{C}^{\wedge} \mathrm{N}$ pincer complex $\mathbf{1}^{15}$ toward $\mathrm{LiHBEt}_{3}$ at low temperature, with the purpose of observing the corresponding hydride. Second, we extended this strategy to bidentate biphenyl-based $\mathrm{C}^{\wedge} \mathrm{C}$ chelating ligands (2), ${ }^{16}$ where the fourth coordination position is occupied by different, nontethered Lewis bases. Finally, we investigated the $\mathrm{C}^{\wedge} \mathrm{N}$ chelate complexes 3, which can be straightforwardly obtained by reacting $\left(\mathrm{C}^{\wedge} \mathrm{N}^{\wedge} \mathrm{C}\right) \mathrm{Au}$ species with the strong Brønsted acid $\left[\mathrm{H}\left(\mathrm{OEt}_{2}\right)_{2}\right]\left[\mathrm{H}_{2} \mathrm{~N}\left\{\mathrm{~B}\left(\mathrm{C}_{6} \mathrm{~F}_{5}\right)_{3}\right\}_{2}\right]$ $\left(\mathrm{HAB}_{2}\right)$. In complexes of type $3,{ }^{17}$ the dangling aromatic substituent acts as a steric protection for the site trans to the cyclometalated aryl group, and this was envisaged to offer the possibility of stabilizing the hydride against reductive elimination.

Using the starting materials $\mathbf{1 - 3}$, we report here several new classes of gold(III) hydrides, including (i) hydrido phosphine complexes, (ii) anionic hydrides, (iii) dihydrides, and (iv) bridging gold(III) hydrides. For the first time it has been possible to synthesize gold(III) complexes with the hydride ligand trans to a strong trans-effect C-donor ligand. We also show that the coordination geometry has an unexpectedly strong influence on the $\mathrm{Au}-\mathrm{H}{ }^{1} \mathrm{H}$ NMR chemical shift, which can cover a range of $\sim 15 \mathrm{ppm}$. Computational studies show that the ${ }^{1} \mathrm{H}$ NMR shifts of gold hydrides are strongly influenced by the spin-orbit coupling as a function of the ligand environment and depend on the nature of both cis and trans ligands. These ligand combinations also affect the thermal stability, leading, for example, to gold(III) phosphine hydrides suitable for crystallographic characterization. The investigation of the reactivity of these new hydrides reveals that they differ distinctly from compounds of type A.

\section{RESULTS AND DISCUSSION}

$\left(C^{\wedge} C^{\wedge} N\right)$ Complexes. $C^{\wedge} C^{\wedge} \mathrm{N}$ pincer complexes are coordination isomers of the much more widely studied $\mathrm{C}^{\wedge} \mathrm{N}^{\wedge} \mathrm{C}$ systems $s^{9,18}$ and show interesting reactivity and photophysical properties. ${ }^{15}$ In bonding terms $\mathrm{C}^{\wedge} \mathrm{C}^{\wedge} \mathrm{N}$ is complementary to $\mathrm{C}^{\wedge} \mathrm{N}^{\wedge} \mathrm{C}$ since strong and weak trans-effect ligands have swapped positions and dissociation of the pyridine moiety is less constrained, so that gold(III) hydrides with enhanced reactivity might be expected. With this aim, we explored the reactivity of $\left(\mathrm{C}^{\wedge} \mathrm{C}^{\wedge} \mathrm{N}\right)$ gold chloride 1 with 1.0 equiv of $\mathrm{LiHBEt}_{3}$ at $198 \mathrm{~K}$. The reaction was monitored by ${ }^{1} \mathrm{H}$ NMR spectroscopy in THF- $d_{8}$ gradually raising the temperature from 203 to $243 \mathrm{~K}$. The ${ }^{1} \mathrm{H}$ NMR spectrum recorded at this temperature showed the clean formation of a single gold-containing species 4 , which retained the typical pattern of a cyclometalated $\left(\mathrm{C}^{\wedge} \mathrm{C}^{\wedge} \mathrm{N}\right)$ system (Scheme 1$)$.

Scheme 1. Generation of Monohydride 4 and the Dihydride $5\left(\mathrm{R}=p\right.$ - $\left.\mathrm{Bu}^{t} \mathrm{C}_{6} \mathrm{H}_{4}\right)$, Showing the Numbering Scheme Used for NMR Assignments

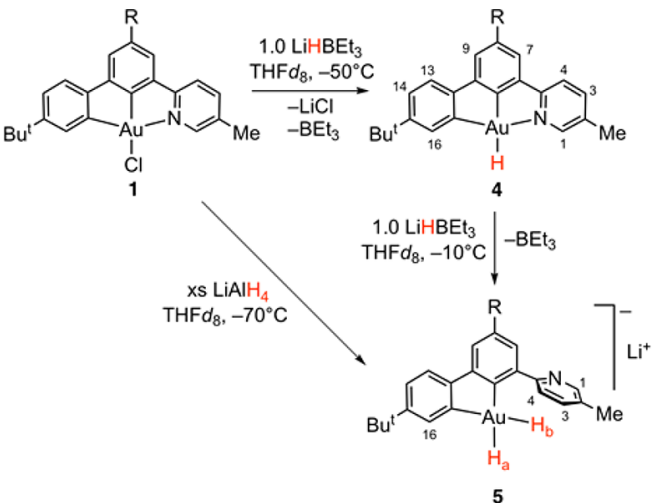

While no precipitate was seen in THF, when the reaction was performed in $\mathrm{CD}_{2} \mathrm{Cl}_{2}$, the formation of solid of $\mathrm{LiCl}$ was observed and free $\mathrm{BEt}_{3}$ was detected in the reaction mixture $\left(\delta_{\mathrm{B}}=+85.1 \mathrm{ppm}\right)$.

Multinuclear and multidimensional NMR experiments performed at $253 \mathrm{~K}$ in THF- $d_{8}$ were consistent with the formulation of $\mathbf{4}$ as the gold hydride $\left(\mathrm{C}^{\wedge} \mathrm{C}^{\wedge} \mathrm{N}\right) \mathrm{AuH} .{ }^{19}$ The ${ }^{1} \mathrm{H}$ NMR chemical shifts of metal hydrides are subject to relativistic spin-orbit (SO) effects ("heavy atom effect on the light-atom shielding", HALA), ${ }^{20,21}$ which in the case of transition metal complexes with $\mathrm{d}^{8}$ electron configuration are typically shielding, ${ }^{20 \mathrm{a}}$ as exemplified by shifts of $\delta_{\mathrm{H}}=-6.58$ $\left(\mathrm{CD}_{2} \mathrm{Cl}_{2}\right)$ and $-8.34 \mathrm{ppm}\left(\right.$ THF- $\left.d_{8}\right)$ for $\mathbf{A}$ and $\mathbf{B}$, respectively. ${ }^{5,7}$ In sharp contrast, the signal for the $\mathrm{Au}-\mathrm{H}$ moiety in 4 is high-frequency shifted at $\delta_{\mathrm{H}}=+6.33 \mathrm{ppm}$. An analysis of the dipolar contacts in the ${ }^{1} \mathrm{H}$ NOESY NMR spectrum revealed selective interactions of the hydride signal with both ortho-protons of the coordinated pyridyl and of the cyclometalated aryl, indicating that the pyridine coordination remains intact upon exchange of chloride by hydride. No interactions with $\mathrm{BEt}_{3}$ groups were observed, excluding the formation of a gold-borohydride Au- $\mathrm{HBEt}_{3}$ complex. This was further confirmed by diffusion NMR experiments, which showed that 4 and $\mathrm{BEt}_{3}$ diffuse with different hydrodynamic 

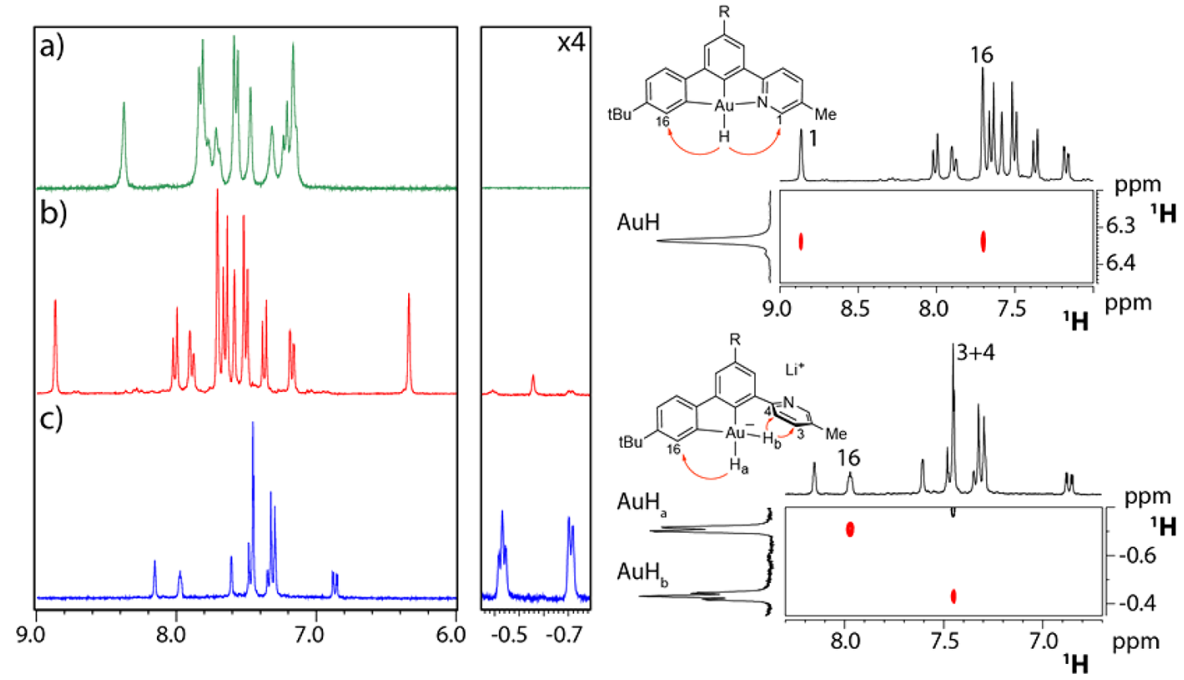

Figure 1. Left: overlay of two sections of the ${ }^{1} \mathrm{H}$ NMR spectra of (a) 1 (203 K, THF- $\left.d_{8}\right)$; (b) 4 (253 K, THF- $\left.d_{8}\right)$; and (c) 5 (263 K, THF- $\left.d_{8}\right)$. Right: a section of the ${ }^{1} \mathrm{H}$ NOESY NMR spectrum of 4 (top, $253 \mathrm{~K}$, THF- $d_{8}$ ) and 5 (bottom, $263 \mathrm{~K}$, THF- $d_{8}$ ).

dimensions. The carbon atom in trans position to the hydride is high-frequency shifted compared with the chloride complex and resonates at $\delta_{\mathrm{C}}=184.2 \mathrm{ppm}$; this shift can be attributed to the strong trans-influence of the $\mathrm{H}^{-}$ligand and concomitant SO-induced deshielding. ${ }^{21,22}$ On the other hand, the second metalated carbon atom is found at $\delta_{\mathrm{C}}=$ $145.3 \mathrm{ppm}$, being trans to the weaker pyridine donor. The NMR peak assignments are also confirmed by relativistic quantum-chemical calculations (cf. Figure S49 in Supporting Information for ${ }^{13} \mathrm{C}$ NMR data) and ${ }^{1} \mathrm{H}$ hydride shifts are analyzed in detail (see Computational analysis below).

In THF solution at room temperature $\mathbf{4}$ is stable only for a few minutes, hampering its successful crystallization. When an NMR sample was warmed from 253 to $298 \mathrm{~K}$, broadening of the $\mathrm{Au}-\mathrm{H}$ and pyridine signals was observed, likely due to pyridine decoordination which may open decomposition pathways. Other solvents, such as benzene- $d_{6}$ or $\mathrm{CD}_{2} \mathrm{Cl}_{2}$, can be used for generating 4, but no improvements in stability were observed. The ${ }^{1} \mathrm{H}$ NMR signal of the $\mathrm{Au}-\mathrm{H}$ moiety is marginally affected by the change of solvents and resonates at $\delta_{\mathrm{H}}=6.99$ and $6.09 \mathrm{ppm}$ in $\mathrm{C}_{6} \mathrm{D}_{6}$ and $\mathrm{CD}_{2} \mathrm{Cl}_{2}$, respectively.

Complex 4 reacts smoothly at room temperature with dimethyl acetylene dicarboxylate (DMAD) under transhydroauration to give a gold vinyl product $(Z / E=95: 5)$. A similar vinyl product has previously been obtained by the thermal decomposition of the gold(III) formate complex $\left(\mathrm{C}^{\wedge} \mathrm{C}^{\wedge} \mathrm{N}\right) \mathrm{AuO}_{2} \mathrm{CH}$ at $100{ }^{\circ} \mathrm{C}$ in the presence of di-tert-butyl acetylenedicarboxylate, presumably via 4 as the intermediate. ${ }^{14}$ On the other hand, 4 proved unreactive toward unactivated alkynes such as 2-butyne or 1-phenyl-1-propyne. This behavior contrasts with that of hydrides of type A, which insert a wide range of alkynes stereoselectively by a radicalmediated outer-sphere mechanism. ${ }^{6}$

When a solution of 4 in THF- $d_{8}$ is treated with 1 or more equivalents of $\mathrm{LiHBEt}_{3}$ at $263 \mathrm{~K}$, the monohydride is quantitatively converted into the unprecedented anionic dihydride complex 5. In striking contrast with what was observed in 4, both the hydride signals of 5 are shielded and located at $\delta_{\mathrm{H}}=-0.59\left(\mathrm{H}_{\mathrm{a}}\right)$ and $-0.31 \mathrm{ppm}\left(\mathrm{H}_{\mathrm{b}}\right) . \mathrm{H}_{\mathrm{a}}$ appears as a doublet with a coupling constant ${ }^{2} J_{H H}=4.2 \mathrm{~Hz}$, while $\mathrm{H}_{\mathrm{b}}$ is a pseudotriplet due to the simultaneous coupling with $\mathrm{H}_{\mathrm{a}}$ and the $\alpha$ proton of the cyclometalated aryl. The assignment of the hydride signals was confirmed by ${ }^{1} \mathrm{H}$ NOESY spectroscopy, which shows selective dipolar interactions between $\mathrm{H}_{b}$ and the $\mathrm{H}^{3} / \mathrm{H}^{4}$ pair of the dangling pyridine, while $\mathrm{H}_{\mathrm{a}}$ interacts specifically with $\mathrm{H}^{16}$ (Figure 1 ). Both carbon atoms attached to gold are high-frequency shifted due to the high trans-influence of the hydride ligands and resonate at $\delta_{\mathrm{C}}=172.3\left(\mathrm{C}\right.$ trans to $\left.\mathrm{H}_{\mathrm{b}}\right)$ and $171.1 \mathrm{ppm}\left(\mathrm{C}\right.$ trans to $\left.\mathrm{H}_{\mathrm{a}}\right)$. The dihydride $\mathbf{5}$ is stable in THF solution for days at room temperature but has so far escaped crystallization. Interestingly, $\mathbf{5}$ can also be prepared quantitatively by using an excess of $\mathrm{LiAlH}_{4}$ as hydride transfer agent, with no sign of reduction. The reaction of $\mathbf{5}$ with DMAD gives a complex mixture, likely arising from possible double insertions and/or vinyl elimination reactions; it did not prove possible to isolate a clean product.

The $\mathbf{C} \wedge$ Ligand System. The formation of $\mathbf{5}$ shows that even anionic gold(III) dihydrides can be made supported by a dianionic $\mathrm{C}^{\wedge} \mathrm{C}$ chelate backbone, rather than by tridentate pincer ligands. We therefore explored similar ligands which lack the tethered pyridine donor. The complex $\left(\mathrm{C}^{\wedge} \mathrm{C}\right) \mathrm{AuCl}-$ (py) $2\left(\mathrm{C}^{\wedge} \mathrm{C}=4,4^{\prime}\right.$-di-tert-butylbiphenyl-2,2'-diyl $)$ was combined with 2.0 equiv of $\mathrm{LiHBEt}_{3}$ in THF- $d_{8}$ at $198 \mathrm{~K}$ and the reaction was monitored by ${ }^{1} \mathrm{H}$ NMR spectroscopy at $223 \mathrm{~K}$. Soon after mixing the reagents, the solution turned bright yellow, and the first NMR spectrum showed the complete consumption of the starting material to give a single clean species showing two different sets of signals for the $\mathrm{C}^{\wedge} \mathrm{C}$ ligand, suggesting the formation of an asymmetric gold complex. ${ }^{1} \mathrm{H}$ NOE and diffusion NMR spectroscopy showed that the py $\rightarrow \mathrm{BEt}_{3}$ Lewis adduct had formed. These data are consistent with pyridine displacement by the hydroborate and elimination of the borane-pyridine adduct, leading to the formation of the chloro hydride anion, $\left[\left(\mathrm{C}^{\wedge} \mathrm{C}\right) \mathrm{Au}(\mathrm{H}) \mathrm{Cl}\right]^{-}$ (6). The reaction of $\mathbf{2}$ is therefore quite different from that of the $\left(\mathrm{C}^{\wedge} \mathrm{C}^{\wedge} \mathrm{N}\right)$ ligand system $\mathbf{1}$, where the pyridine was not initially displaced. The $\mathrm{Au}-\mathrm{H}$ moiety in $\mathbf{6}$ was identified as a broad singlet at $\delta_{\mathrm{H}}=+2.43 \mathrm{ppm}$, which showed selective dipolar interactions with only one $\alpha$ proton of the ligand at $\delta_{\mathrm{H}}=7.72 \mathrm{ppm}$. As observed for 4 , the two metalated carbon atoms resonate at quite different frequencies, due to the different trans-influences of the chloride and hydride ligands, such that $\mathrm{C}$ trans to $\mathrm{H}$ resonates at $\delta_{\mathrm{C}}=174.8 \mathrm{ppm}$, while $\mathrm{C}$ 
trans to $\mathrm{Cl}$ is found at $148.4 \mathrm{ppm}$. Product 6 is stable in solution for hours at $213 \mathrm{~K}$, but upon raising the temperature to $253 \mathrm{~K}$ it is converted to an undefined secondary species showing a broad hydride signal at $\delta_{\mathrm{H}}=+0.9 \mathrm{ppm}$. Diffusion NMR experiments in $\mathrm{CD}_{2} \mathrm{Cl}_{2}$ at $228 \mathrm{~K}$ suggested the formation of aggregates containing at least four gold centers. This species undergoes reductive decomposition above $253 \mathrm{~K}$, and its identity could not be ascertained. Since this reactivity was likely due to the facile chloride elimination from $\mathbf{6}$, we explored more strongly coordinating bases to stabilize the hydride products.

In order to intercept a $\left(\mathrm{C}^{\wedge} \mathrm{C}\right) \mathrm{Au}$ hydride of a structure comparable to 4, the chloro hydride 6 was reacted with $1 \mathrm{~mol}$ equiv of $p$-dimethylaminopyridine (DMAP) at $195 \mathrm{~K}$ and the resulting mixture was monitored by ${ }^{1} \mathrm{H}$ NMR spectroscopy at $253 \mathrm{~K}$. Although at a 1:1 stoichiometry DMAP does not bind to gold but displaces pyridine from the py $\rightarrow \mathrm{BEt}_{3}$ adduct, with 4.0 equiv of DMAP 6 is converted quantitatively to $\left(\mathrm{C}^{\wedge} \mathrm{C}\right) \mathrm{AuH}(\mathrm{DMAP})(7)$ (Scheme 2). This complex shows a

Scheme 2. Synthesis and Reactions of $\left(\mathrm{C}^{\wedge} \mathrm{C}\right)$ Gold(III) Hydrides, Showing the Atom Numbering Scheme Used for NMR Assignments, and the Molecular Structure of the Insertion Product $12^{a}$

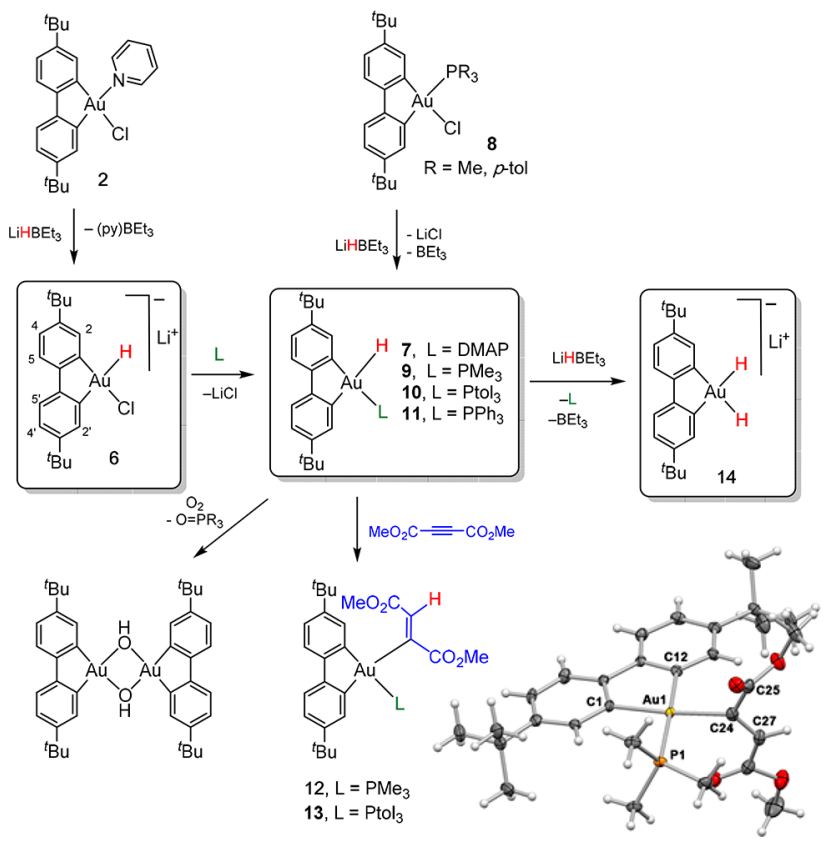

${ }^{a}$ Selected bond distances $[\AA]$ and angles $\left[{ }^{\circ}\right]$ : Au1-C1 2.079(7), Au1C12 2.070(6), Au1-P1 2.353(2), Au1-C24 2.078(7), C1-Au1-C12 81.1(3), C1-Au1-P1 96.8(2), P1-Au1-C24 89.7(2), C24-Au1C12 92.3(3), C1-Au1-C24 173.4(3), C12-Au1-P1 177.3(2), torsion $\mathrm{C} 1-\mathrm{Au} 1-\mathrm{C} 24-\mathrm{C} 25$ 91(2), torsion $\mathrm{C} 1-\mathrm{Au} 1-\mathrm{C} 24-\mathrm{C} 27-$ $88(3)$.

hydride signal at $\delta_{\mathrm{H}}=+3.25 \mathrm{ppm}$, which exhibits $\mathrm{NOE}$ interactions with one $\alpha$ proton of the $\mathrm{C}^{\wedge} \mathrm{C}$ ligand and with the ortho protons of the coordinated DMAP $\left(\delta_{\mathrm{H}}=8.10\right) .{ }^{1} \mathrm{H}$ NOESY NMR reveals that at $253 \mathrm{~K}$ free and coordinated DMAP are in chemical exchange. Likely for this reason, 7 decomposes at room temperature within about $30 \mathrm{~min}$.

By contrast, thermally stable hydrides are straightforwardly obtained by reacting the phosphine complexes $\left(\mathrm{C}^{\wedge} \mathrm{C}\right) \mathrm{Au}(\mathrm{Cl})$ $\mathrm{PR}_{3} 8\left(\mathrm{R}=\mathrm{Me}, \mathrm{p}\right.$-tolyl) with $\mathrm{LiHBEt}_{3}$ in toluene at room temperature to give spectroscopically clean samples of 9 and 10, respectively, which were isolated by filtration and vacuum drying. The same complexes, as well as the $\mathrm{PPh}_{3}$ derivative 11, are also accessible from the chloro hydride 6 on reaction with phosphines. However, in that case purification and crystallization of the products was hampered by the presence of the py $\rightarrow \mathrm{BEt}_{3}$ byproduct, which displays similar solubility characteristics to $\mathbf{9 - 1 1}$ in organic solvents.

The complexes 9-11 are stable in THF solution at room temperature for several days. The ${ }^{31} \mathrm{P}$ NMR spectra showed high-frequency shifted signals at $\delta_{\mathrm{P}}=-8.2, \delta_{\mathrm{P}}=32.6$, and $\delta_{\mathrm{P}}$ $=34.9 \mathrm{ppm}$ for $\mathbf{9}, \mathbf{1 0}$, and 11, respectively, confirming phosphine coordination. The ${ }^{1} \mathrm{H}$ NMR hydride signals at 1.53 (9), 2.33 (10), and $2.40 \mathrm{ppm}$ (11) appear as doublets due to their coupling with the phosphorus atoms. The ${ }^{2} J_{\mathrm{PH}}$ values (32.6 $\mathrm{Hz}$ for 9, 33.0 for $\mathbf{1 0}$ and $32.3 \mathrm{~Hz}$ for 11) are compatible with $\mathrm{H}$ and $\mathrm{P}$ in cis-positions. ${ }^{2} J_{\mathrm{PC}}$ values are in agreement with the proposed structures: trans couplings fall between 130 and $140 \mathrm{~Hz}$, while cis ${ }^{2} J_{\mathrm{PC}}$ constants are about 4-5 Hz.

Single crystals of 9 were obtained by the slow evaporation of a dry diethyl ether solution under an $\mathrm{N}_{2}$ atmosphere. The structure contains four independent molecules in the asymmetric unit, with very similar structural parameters. Figure 2 gives the geometric parameters of just one of these

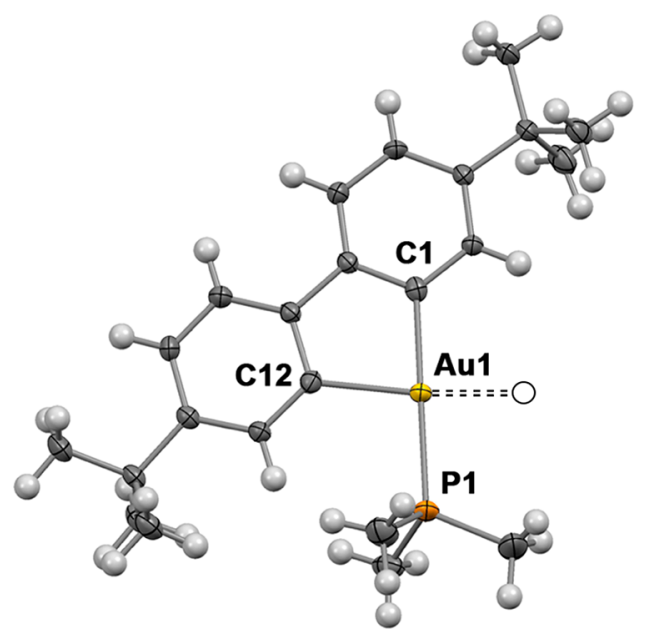

Figure 2. Molecular structure of $\left(\mathrm{C}^{\wedge} \mathrm{C}\right) \mathrm{AuH}\left(\mathrm{PMe}_{3}\right)$ 9; the approximate hydride position is indicated by an open circle. Selected bond distances $[\AA]$ and angles $\left[{ }^{\circ}\right]$ : Au1-C1 2.047(4), Au1-C12 2.115(4), Au1-P1 2.325(1), C1-Au1-C12 81.5(2), C12-Au1-P1 98.7(1), C1-Au1-P1 179.6(1).

molecules. A complete description of the structure is given in the Supporting Information. Locating the position of the hydride next to a heavy atom correctly by crystallography is intrinsically difficult; however, the Fourier map for the $\mathrm{Au}$ coordination plane unequivocally reveals the presence of electron density at a distance of about $1.4 \AA$ (see Supporting Information, Figure S45). The other structural parameters are as expected for a square planar $\mathrm{Au}(\mathrm{III})$ complex. From the differences between the two $\mathrm{Au}-\mathrm{C}$ bonds of the $\mathrm{C}^{\wedge} \mathrm{C}$ ligand, the hydride exerts a larger trans influence than the phosphine

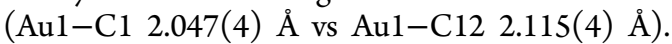

Although solid samples of 9-11 are thermally stable under ambient conditions, crystallization attempts of 9 in toluene also revealed that over time reductive $\mathrm{C}-\mathrm{H}$ elimination and 
ligand rearrangements are possible, as indicated by the isolation of the gold(I) complex $\left[\left(t \mathrm{BuC}_{6} \mathrm{H}_{3}\right)_{2}\left(\mathrm{AuPMe}_{3}\right)_{2}\right]_{x}$ as a byproduct (see Supporting Information, Figure S46). Furthermore, unlike the $\left(\mathrm{C}^{\wedge} \mathrm{N}^{\wedge} \mathrm{C}\right) \mathrm{AuH}$ hydrides of type $\mathrm{A}$ which are stable to air, moisture and weak acids, solutions of 9-11 are sensitive to exposure to air. For example, a sample of 10 left to crystallize without a protective atmosphere afforded the crystallographically identified hydroxide $\left[\left(C^{\wedge} C\right)\right.$ $\mathrm{Au}(\mu-\mathrm{OH})]_{2}$, together with $(p \text {-tol })_{3} \mathrm{P}=\mathrm{O}$ (see SI, Figure S47). The formation of these products suggests $\mathrm{O}_{2}$ insertion into the $\mathrm{Au}-\mathrm{H}$ bond ${ }^{23}$ to give an $\mathrm{Au}(\mathrm{OOH})\left(\mathrm{PR}_{3}\right)$ intermediate, which decomposes to the gold hydroxide with oxidation of the phosphine. This reactivity was also observed upon reacting 10 with dry $\mathrm{O}_{2}$.

As in the case of 4, the hydrides 9 and 10 insert DMAD to give the corresponding $Z$-vinyl complexes 12 and 13 . However, whereas 4 reacts instantaneously with DMAD at room temperature, the same reaction with 9 and $\mathbf{1 0}$ proceeds more slowly. When $1-2$ mol equiv of DMAD are used, 9 is consumed within $2 \mathrm{~h}$, while the reaction of 10 takes about 12 $\mathrm{h}$, likely due to the increased steric repulsion of the phosphine ligands. The reaction affording $\mathbf{1 2}$ is quantitative, whereas $\mathbf{1 3}$ is formed in $80 \%$ yield together with unidentified side products.

The stereochemistry of the DMAD hydroauration products was proved by ${ }^{1} \mathrm{H}$ NOE NMR spectroscopy, which showed the presence of dipolar contacts between the vinylic $\mathrm{CH}$ and both the methoxy groups. No signs of $Z / E$ isomerization were observed after 2 days in solution. Single crystals of $\mathbf{1 2}$ suitable for X-ray diffraction were obtained by slow evaporation of a toluene/dichloromethane solution. The crystal structure confirmed the trans-orientation of the two methylcarboxylate moieties. The vinyl group adopts a perpendicular orientation with respect to the coordination plane of $\mathrm{Au}$ (torsion angle $\left.\mathrm{C} 1-\mathrm{Au} 1-\mathrm{C} 24-\mathrm{C} 2788(3)^{\circ}\right)$. The planar disposition of the $\mathrm{C} 28(\mathrm{O}) \mathrm{OMe}$ carboxylate group and the vinyl moiety is indicative of $\pi$-delocalization; the other carboxylate residue adopts a twisted geometry. The orientation of the carboxylate groups is stabilized in the solid state by a network of intermolecular $\mathrm{O} \cdots \mathrm{H}$ interactions.

The addition of a second molar equivalent of $\mathrm{LiHBEt}_{3}$ to 9 and $\mathbf{1 0}$ leads to the substitution of the phosphine ligand by $\mathrm{H}^{-}$, to give the anionic cis-dihydride 14 (Scheme 2). For example, upon reacting 10 with 1.0 equiv $\mathrm{LiHBEt}_{3}$ at room temperature in THF- $d_{8},{ }^{31} \mathrm{P}$ NMR spectroscopy revealed the disappearance of the signal at $\delta_{\mathrm{P}}=32.6$ and the concomitant formation of free para-tolyl phosphine $\left(\delta_{\mathrm{P}}=-8.0\right)$. The ${ }^{1} \mathrm{H}$ $\mathrm{NMR}$ spectrum indicated a $C_{2}$-symmetric $\mathrm{C}^{\wedge} \mathrm{C}$ ligand, together with a new signal at $\delta_{\mathrm{H}}=0.09$ which accounts for two protons and is assigned to $\mathrm{Au}-\mathrm{H}$ (Supporting Information, Figures S23-S24). The hydride signal appears as a pseudotriplet, due to coupling with the two $\mathrm{C}^{\wedge} \mathrm{C}$ ring protons in 2 and 2 positions; these protons also show selective NOE interactions with the hydride signal. In agreement with these observations, the $\mathrm{Au}-\mathrm{C}$ carbon atoms resonate at $\delta_{\mathrm{C}}=170.7$ in the ${ }^{13} \mathrm{C}$ NMR spectrum. Complex 14 can be also generated in toluene- $d_{8}$, for which the hydride resonance of the $\mathrm{AuH}_{2}$ moiety was found at $\delta_{\mathrm{H}}=1.00 \mathrm{ppm}$. Given that for cis- $\left(\mathrm{Ph}_{3} \mathrm{P}\right) \mathrm{AuClH}(\mathrm{Ph})$ and cis- $\left(\mathrm{Ph}_{3} \mathrm{P}\right) \mathrm{AuClH}_{2}$ the calculated barriers for $\mathrm{C}-\mathrm{H}$ reductive elimination are only 7.5 and $6.5 \mathrm{kcal} \mathrm{mol}^{-1}$, respectively, ${ }^{24}$ and considering the lack of orbital directionality of $\mathrm{H}$, the observed thermal stability of gold(III) hydrido aryls 9-11 and of the dihydride 14 is remarkable and unexpected. As was seen for 10, eventually reductive decomposition does take place, and although 14 appears stable at room temperature for hours in THF and toluene solutions, any isolation attempts led to reductive decomposition, affording free biphenyl and metallic gold.

Other gold cis-hydrido aryl complexes resistant to reductive elimination are similarly accessible, by treatment of the pentafluorophenyl complex $\left[\mathrm{NBu}_{4}\right]\left[\left(\mathrm{C}^{\wedge} \mathrm{C}\right) \mathrm{Au}(\mathrm{Cl}) \mathrm{C}_{6} \mathrm{~F}_{5}\right]$ (15) at room temperature with 1.2 equiv $\mathrm{LiHBEt}_{3}$. The anionic hydride $\mathbf{1 6}$ is formed in quantitative yield, according to ${ }^{1} \mathrm{H}$ NMR spectroscopy (Scheme 3). The chloride-to-hydride

Scheme 3. Synthesis of $\mathrm{NBu}_{4}\left[\left(\mathrm{C}^{\wedge} \mathrm{C}\right) \mathrm{AuH}\left(\mathrm{C}_{6} \mathrm{~F}_{5}\right)\right](16)$ and the Formation and Molecular Structure of the Alkyne Insertion Product $17\left(\mathrm{NBu}_{4}^{+} \text {Omitted for Clarity }\right)^{a}$

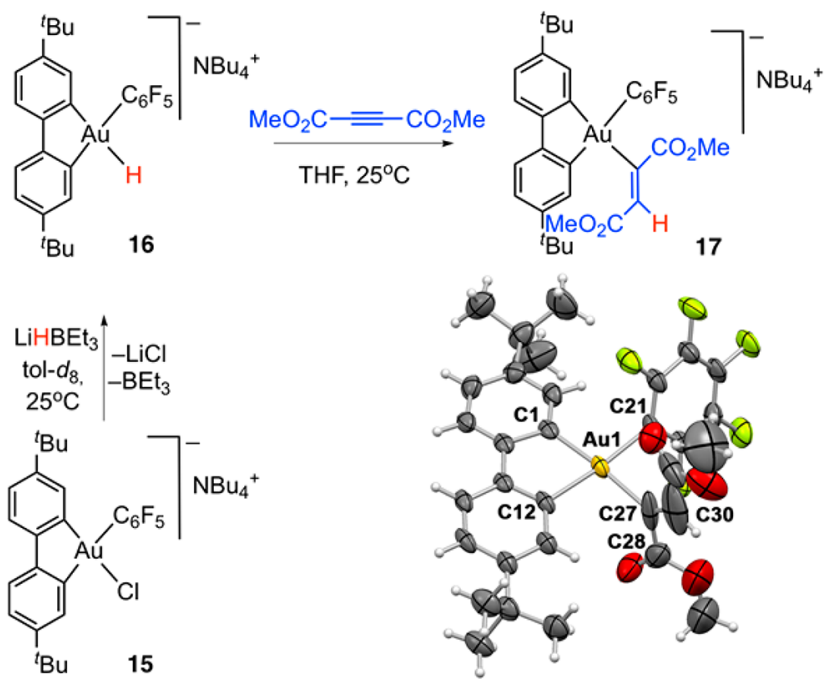

${ }^{a}$ Selected bond distances $[\AA]$ and angles $\left[^{\circ}\right]$ : Au1-C1 2.046(8), Au1C12 2.063(6), Au1-C27 2.093(8), Au1-C21 2.088(6), C27-C28 1.57(2), C27-C30 1.22(2), C1-Au1-C12 80.8(3), C1-Au1-C21 93.7(3), C21-Au1-C27 89.9(3), C27-Au1-C12 95.7(3), C1-Au1C27 174.4(3), C12-Au1-C21 174.4(3).

exchange in THF- $d_{8}$ is comparatively slow and complete within $24 \mathrm{~h}$, whereas in toluene the formation of $\mathbf{1 6}$ is instantaneous. The $\mathrm{Au}-\mathrm{H}$ signal resonates at $\delta_{\mathrm{H}}=1.15 \mathrm{ppm}$ in THF- $d_{8}$, partially overlapping with a tert-butyl signal, and was identified by means of its selective dipolar interaction with the $\mathrm{H}^{2}$ proton of the cyclometalated aryl ring at $\delta_{\mathrm{H}}=$ $8.06 \mathrm{ppm}$. As was seen previously for neutral $\mathrm{C}^{\wedge} \mathrm{C}$ hydrides, the cyclometalated carbon atom trans to the hydride is highfrequency shifted to $\delta_{\mathrm{C}}=170.3$, while the one trans to $\mathrm{C}_{6} \mathrm{~F}_{5}$ resonates at $\delta_{\mathrm{C}}=160.1 \mathrm{ppm}$. Complex 16 reacts readily with DMAD to give the corresponding trans-vinyl complex 17 . In contrast with the phosphine hydrides 9 and 10, the reaction with $\mathbf{1 6}$ is instantaneous at room temperature. The stereochemistry was confirmed by ${ }^{1} \mathrm{H}$ NOESY NMR spectroscopy and by single crystal X-ray diffraction of 17 (Scheme 3). The structural parameters of the anionic vinyl 17 are very similar to those found for $\mathbf{1 2}$.

While phosphine dissociation and creation of a coordination site cis to the hydride could in principle be considered a possible pathway in the reactions of phosphine hydrides 9 and 10 with $\mathrm{DMAD}$, the facile alkyne insertion into the $\mathrm{Au}-\mathrm{H}$ bond of 16, where no such ligand dissociation is possible, shows that alkyne $\pi$-coordination to $\mathrm{Au}(\mathrm{III})-\mathrm{H}$ is not part of 
the insertion process. We also established that, unlike the insertion reactions of $\left(\mathrm{C}^{\wedge} \mathrm{N}^{\wedge} \mathrm{C}\right) \mathrm{AuH}$ (A) with alkyl and aryl acetylenes, ${ }^{6}$ a radical chain reaction via $\mathrm{Au}(\mathrm{II})$ intermediates is not involved.

While a detailed study of this insertion mechanism is beyond the scope of this work, it is apparent that only alkynes with a low reduction potential insert into the gold hydrides described here. A similar observation was made with the gold(I) hydride (IPr)AuH (IPr = 1,3-bis(diisopropylphenyl)imidazol-2-ylidene). ${ }^{4}$ DMAD has a reduction potential of only $-0.8 \mathrm{~V}$ (compared to a value of $-2.1 \mathrm{~V}$ for diphenylacetylene) ${ }^{25}$ It seems likely therefore that the insertion of DMAD follows an electron transfer mechanism, which would generate an alkyne radical anion within the solvent cage. Alkyne radical anions are known to exhibit trans geometry, ${ }^{26}$ and such an intermediate, followed by $\mathrm{H}$ abstraction and $\mathrm{Au}-\mathrm{C}$ bond formation, would explain the observed $Z$-vinyl stereochemistry of DMAD hydroauration (Scheme 4). The reactivity of our

Scheme 4. Proposed Mechanism of DMAD Hydroauration with $\left(\mathrm{C}^{\wedge} \mathrm{C}\right)$ Au Hydrides

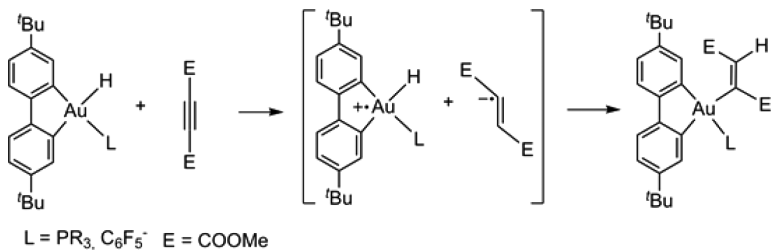

gold(III) hydrides seems to resemble therefore the DMAD insertion process observed for platinum dihydrides trans$\mathrm{H}_{2} \mathrm{Pt}\left(\mathrm{PR}_{3}\right)_{2}$ (but not for trans- $\mathrm{PtH}(\mathrm{Cl})\left(\mathrm{PEt}_{3}\right)_{2}$, which follows a coordination-cis insertion pathway). ${ }^{27}$

Reactivity of $(\mathrm{C} \wedge \mathrm{C})$ Gold Vinyl Complexes. As we observed previously, $\left(\mathrm{C}^{\wedge} \mathrm{N}^{\wedge} \mathrm{C}\right) \mathrm{Au}(\mathrm{III})$ vinyl complexes obtained by alkyne trans-hydroauration are thermally stable and are not protodeaurated by strong acids. ${ }^{6}$ This might be ascribed to the effect of the weak pyridine donor trans to vinyl, which strengthens the $\mathrm{Au}-\mathrm{C}$ bond. In 12, 13, and 17, the vinyl ligands are trans to anionic carbon, which exerts a much stronger trans effect and thus labilize the Au-vinyl bond. In order to investigate whether this structural modification has an impact on the reactivity of these complexes, we explored photoisomerization, protodeauration, and reduction with $\mathrm{LiHBEt}_{3}$ of these gold vinyls.

Photoisomerization of 12 and 17 was performed by irradiating samples in THF- $d_{8}$ at $365 \mathrm{~nm}$ for $2 \mathrm{~h}$ at room temperature. 12 does not photoisomerize easily under these conditions and gives a thermodynamic $E / Z$ ratio of 20:80, whereas the anionic vinyl complex 17 leads to an equilibrium $E / Z$ ratio of 50:50. This supports the hypothesis that the $Z$ isomer obtained upon hydroauration of DMAD is the kinetic product and that the structure of the ancillary ligand has an impact on the isomer distribution in the thermodynamic mixture.

The reactivity of $\left(\mathrm{C}^{\wedge} \mathrm{C}\right) \mathrm{Au}$ vinyl complexes toward acids and hydrides was exemplified for 12. On treatment with 2.5 equiv of $\mathrm{LiHBEt}_{3}, \mathbf{1 2}$ reacts quantitatively under selective reduction of one of the two ester functions to give the alkoxyvinyl product 18 (Scheme 5). The identity of 18 was confirmed by multinuclear and multidimensional NMR spectroscopy (Supporting Information). This reactivity demonstrates the facile postsynthesis derivatization of alkyne
Scheme 5. Photoisomerization, Ester Reduction, and Reductive C-C Bond Formation of Gold Vinyl Complexes

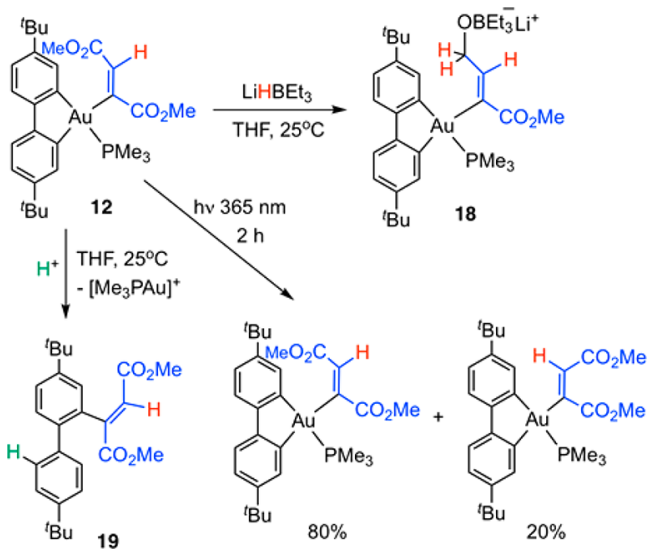

hydroauration products and their remarkable resistance to reducing conditions.

Reductive elimination of a $\mathrm{C}-\mathrm{C}$ cross-coupling product can be induced by acids. When a solution of $\mathbf{1 2}$ in THF- $d_{8}$ was treated with the strong Brønsted acid $\left[\mathrm{H}\left(\mathrm{OEt}_{2}\right)\right]\left[\mathrm{H}_{2} \mathrm{~N}\{\mathrm{~B}\right.$ $\left.\left.\left(\mathrm{C}_{6} \mathrm{~F}_{5}\right)_{3}\right\}_{2}\right]^{28}$ (1 equiv) at room temperature, the orange color of the solution faded immediately and a dark precipitate of metallic gold was observed. The ${ }^{1} \mathrm{H}$ NMR spectrum of the supernatant revealed the formation of the 2-vinylbiphenyl 19 in about $65 \%$ yield. Protodeauration of the Au-vinyl bond to give $\mathrm{MeO}_{2} \mathrm{CH}=\mathrm{CHCO}_{2} \mathrm{Me}$ was not detected. The appearance of an $\mathrm{AX}$ system at $\delta_{\mathrm{H}}=7.20$ and 7.34 ppm suggests that the acid protodeaurates selectively one $\mathrm{Au}-\mathrm{C}$ bond of the cyclometalated $\mathrm{C}^{\wedge} \mathrm{C}$ ligand, likely trans to vinyl, to give a cationic aryl-vinyl intermediate capable of reductive $\mathrm{C}-\mathrm{C}$ coupling. This Au-aryl bond cleavage kinetically outperforms Au-vinyl protonation. The stereochemistry of the vinyl group is retained in 19.

The $\mathrm{C} \wedge \mathrm{N}-\mathrm{CH}$ Ligand System. Protodeauration of $\left(\mathrm{C}^{\wedge} \mathrm{N}^{\wedge} \mathrm{C}\right) \mathrm{Au}(\mathrm{III})$ pincer complexes with $\mathrm{HAB}_{2}$ affords cleaved $\left(\mathrm{C}^{\wedge} \mathrm{N}-\mathrm{CH}\right) \mathrm{Au}(\mathrm{III})$ cations 3 (Scheme 6), where a $\mathrm{Et}_{2} \mathrm{O}$ molecule is weakly coordinated to gold in trans position to the remaining cyclometalated aryl. ${ }^{17} \mathrm{We}$ therefore envisioned that this particular ligand environment could

Scheme 6. Formation of Binuclear $\mathrm{C}^{\wedge} \mathrm{N}$ Bonded Gold(III) Hydrides

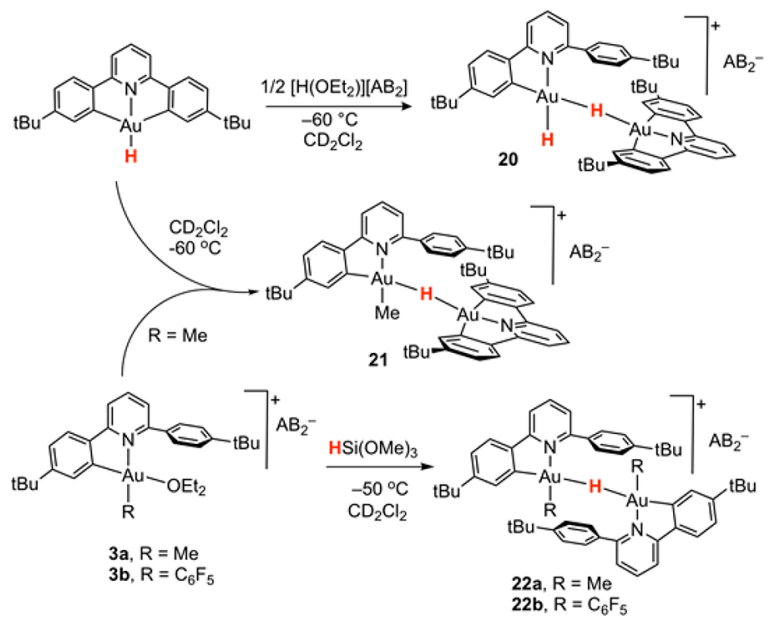


offer the possibility to intercept yet another family of $\mathrm{Au}$ (III) hydrides which could also have the hydride ligand trans to a carbon atom but, being supported by a $\mathrm{C}^{\wedge} \mathrm{N}$ rather than a $\mathrm{C}^{\wedge} \mathrm{C}$ chelate, would constitute the cationic analogues of the $\left(\mathrm{C}^{\wedge} \mathrm{C}\right) \mathrm{AuH}(\mathrm{L})$ species described above. Moreover, the presence of the dangling aryl group might offer extra steric protection to the hydride moiety.

As a first control experiment, we reinvestigated the reaction of $\left(\mathrm{C}^{\wedge} \mathrm{N}^{\wedge} \mathrm{C}\right) \mathrm{AuH}$ with $\mathrm{HAB}_{2}$ at a $1: 1$ molar ratio. As previously reported, the $\mathrm{Au}-\mathrm{H}$ bonds in pincer gold(III) hydrides are covalent and do not liberate $\mathrm{H}_{2}$ upon reaction with acids. Instead, one $\mathrm{Au}-\mathrm{C}$ bond is protolytically cleaved, a process that can be expected to enable fast reductive $\mathrm{C}-\mathrm{H}$ elimination. ${ }^{29}$ To our surprise, when the protodeauration reaction was performed at $213 \mathrm{~K}$ in $\mathrm{CD}_{2} \mathrm{Cl}_{2}$, the starting material was quantitatively converted to the new species 20 . This complex shows two scalarly coupled hydride signals, both at much lower frequency than the ones seen for $\mathrm{C}^{\wedge} \mathrm{C}$ complexes, $\delta_{\mathrm{H}}=-4.88$ and $\delta_{\mathrm{H}}=-8.39 \mathrm{ppm}$. In the aromatic region of the ${ }^{1} \mathrm{H}$ NMR spectrum there are two sets of signals in a 1:1 ratio, with one set showing the typical fingerprint of a cleaved $\left(\mathrm{C}^{\wedge} \mathrm{N}-\mathrm{CH}\right)$ ligand, while the second set was that of an intact $\left(\mathrm{C}^{\wedge} \mathrm{N}^{\wedge} \mathrm{C}\right) \mathrm{Au}$ fragment. In agreement with this, only $50 \%$ of the added acid had in fact reacted, with the other $50 \%$ remaining unchanged $\left(\delta_{\mathrm{H}}=16.7 \mathrm{ppm}\right)$. These findings were consistent with protodeauration of one pincer $\mathrm{Au}-\mathrm{C}$ bond to generate a cationic gold hydride, followed by coordination of a molecule of neutral $\left(\mathrm{C}^{\wedge} \mathrm{N}^{\wedge} \mathrm{C}\right) \mathrm{AuH}$ to the vacant coordination site on the $\left[\left(\mathrm{C}^{\wedge} \mathrm{N}-\mathrm{CH}\right) \mathrm{AuH}\right]^{+}$cation to give the H-bridged binuclear dihydride 20 (Scheme 6). Whereas in gold(I) chemistry H-bridged complexes are not uncommon, ${ }^{4}$ this is the first example of a bridging hydride in gold(III) chemistry. In agreement with the reaction sequence outlined above, the same product can be generated using only 0.5 equiv of acid. The geminal coupling constants for the dihydride was found to be $8.2 \mathrm{~Hz}$, much larger than the geminal coupling in the anionic mononuclear dihydride 6 $\left({ }^{2} J_{H H}=4.2 \mathrm{~Hz}\right) \cdot{ }^{1} \mathrm{H}$ NOESY methods allowed us to assign the signals at $\delta_{\mathrm{H}}=-4.88$ and $\delta_{\mathrm{H}}=-8.39 \mathrm{ppm}$ to the bridging and the terminal hydride, respectively. Unfortunately, the dihydride 20 is thermally unstable and at $213 \mathrm{~K}$ decomposes over a period of $1 \mathrm{~h}$, hampering full ${ }^{13} \mathrm{C}$ NMR characterization.

In analogy to complex 20, the cationic gold(III) methyl complex 3a reacts with 1 equiv of $\left(\mathrm{C}^{\wedge} \mathrm{N}^{\wedge} \mathrm{C}\right) \mathrm{AuH}$ at $213 \mathrm{~K}$ to give the bridging hydride $21\left(\delta_{\mathrm{H}}=-5.14 \mathrm{ppm}\right)$. Product 21 proved to be rather unstable and decomposed at low temperature within hours, in line with the low barrier of reductive methane elimination calculated for $\left(\mathrm{Ph}_{3} \mathrm{P}\right) \mathrm{AuH}$ -

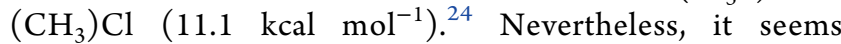
remarkable that gold hydrido methyl complexes are so readily accessible.

In the search for milder hydride donors, the reactions of the cleaved pincer complexes $\mathbf{3} \mathbf{a}$ and $\mathbf{3} \mathbf{b}$ with $\mathrm{HSi}(\mathrm{OMe})_{3}$ were tested. Complexes 22a $(\mathrm{R}=\mathrm{Me})$ and $22 \mathrm{~b}\left(\mathrm{R}=\mathrm{C}_{6} \mathrm{~F}_{5}\right)$ proved to be more stable than 20 and 21 and could be fully characterized by multinuclear NMR at low temperature. The hydride signal appeared as singlets at $\delta_{\mathrm{H}}=-2.53$ and $\delta_{\mathrm{H}}=$ $-2.21 \mathrm{ppm}$ for 22a and 22b, respectively (Supporting Information, Figure S41). The ${ }^{1} \mathrm{H}$ NMR spectra of complexes 22a,b show the presence of four different signals for the dangling aryl substituents, suggesting that dimerization of two gold units blocks the free rotation of the aromatic ring about the $\mathrm{C}-\mathrm{C}$ bond. ${ }^{1} \mathrm{H}$ NOESY NMR spectroscopy revealed the presence of selective dipolar interactions between the bridging hydride and only one proton of the protodeaurated ring, confirming that the $\mathrm{Au}-\mathrm{H}-\mathrm{Au}$ moiety is located in the pocket formed by the two paired cleaved pincer complexes. In the case of complex 22a, the same interaction was observed for the $\mathrm{Au}-\mathrm{Me}$ moiety.

Although complexes 22a,b are stable at $253 \mathrm{~K}$, they decompose at room temperature, following reaction pathways which depend on the substituents on gold. Warming a sample of $22 \mathbf{b}$ to $297 \mathrm{~K}$ generates $\mathrm{C}_{6} \mathrm{~F}_{5} \mathrm{H}$ quantitatively within minutes; in this case the reductive coupling of $\mathrm{H}$ with $\mathrm{C}_{6} \mathrm{~F}_{5}$ is preferred. The methyl complex 22a is slightly more thermally stable and survives $297 \mathrm{~K}$ for about $30 \mathrm{~min}$ before decomposing. However, there is no elimination of $\mathrm{CH}_{4}$; instead, the methyl migrates to the $\mathrm{C}^{\wedge} \mathrm{N}^{\wedge} \mathrm{C}$ ligand, while the hydride is likely eliminated through reductive deprotonation to give protonated pyridinium salts. ${ }^{30}$

Connection between Gold Hydride ${ }^{1} \mathrm{H}$ NMR Chemical Shifts and Electronic Structure. The gold(III) hydride complexes described above are characterized by a spread of ${ }^{1} \mathrm{H}$ NMR chemical shifts covering an unexpectedly wide range of about $15 \mathrm{ppm}$. Table 1 summarizes the relevant structural, calculated and experimental data. Particularly striking is the difference between the regioisomeric pincer complexes $\left(\mathrm{C}^{\wedge} \mathrm{N}^{\wedge} \mathrm{C}\right) \mathrm{AuH}$ and $\left(\mathrm{C}^{\wedge} \mathrm{C}^{\wedge} \mathrm{N}\right) \mathrm{AuH}$, which show resonances of $\delta-6.51$ and $+6.09 \mathrm{ppm}$, respectively (both in $\mathrm{CD}_{2} \mathrm{Cl}_{2}$ ). While the former features an upfield (low-frequency) shift often seen for diamagnetic hydride complexes with a partially filled d-shell, ${ }^{19}$ the latter displays a notable downfield ${ }^{1} \mathrm{H}$ shift, resembling that in a gold(I) hydride, (IPr)AuH, ${ }^{4}$ although both $\left(\mathrm{C}^{\wedge} \mathrm{N}^{\wedge} \mathrm{C}\right) \mathrm{AuH}$ and $\left(\mathrm{C}^{\wedge} \mathrm{C}^{\wedge} \mathrm{N}\right) \mathrm{AuH}$ contain the metal center in the same +III oxidation state. To rationalize the observed trends and to gain insight into the electronic structures and the factors that result in these spectroscopic differences, we turned to relativistic quantum-chemical calculations of structures and ${ }^{1} \mathrm{H}$ NMR hydride shifts at the two-component ZORA-SO level, including spin-orbit coupling (see Supporting Information for computational details). ${ }^{31,32}$

All investigated structures were optimized at the PBE0D3(BJ)/ECP/def2-TZVP level using a quasi-relativistic smallcore pseudopotential for gold, along with atom-pairwise corrections for dispersion forces. First, we note an excellent agreement between X-ray and DFT optimized structures, with differences in $\mathrm{Au}-\mathrm{L}$ bond-lengths of less than $0.02 \AA$, except for the $\mathrm{Au}-\mathrm{H}$ bonds, where values determined by X-ray diffraction are often much larger (by up to $0.15 \AA$ ) than found computationally (cf. Figure S48 in Supporting Information). The precise detection of the hydride position by X-ray crystallography, however, suffers from weak scattering of X-rays by light $\mathrm{H}$ atoms and these data should be taken with caution. The reliability of DFT-determined Au$\mathrm{H}$ bond-lengths is demonstrated by the excellent agreement between computed and experimental ${ }^{1} \mathrm{H}$ hydride shifts for the optimized structures, with a standard deviation of $0.4 \mathrm{ppm}$ (see Figure S50 in Supporting Information). We also note a very good match between experimental and calculated ${ }^{2} J_{\mathrm{HP}}$ coupling constants in the hydrido phosphine complexes 9 $\left({ }^{2} J_{\text {expt }}=32.6 \mathrm{~Hz} ;{ }^{2} J_{\text {calcd }}=31.4 \mathrm{~Hz}\right)$ and $10\left({ }^{2} J_{\text {expt }}=32.3 \mathrm{~Hz}\right.$; $\left.{ }^{2} J_{\text {calcd }}=30.9 \mathrm{~Hz}\right)$.

The experimental ${ }^{1} \mathrm{H}$ NMR shifts of terminal hydride atoms are found to correlate well with DFT optimized $\mathrm{Au}-\mathrm{H}$ 
Table 1. DFT Optimized Au-H Bond Lengths (in Å) and Computed and Experimental ${ }^{1} \mathrm{H}$ NMR Hydride Chemical Shifts of Gold Hydrides $^{a}$

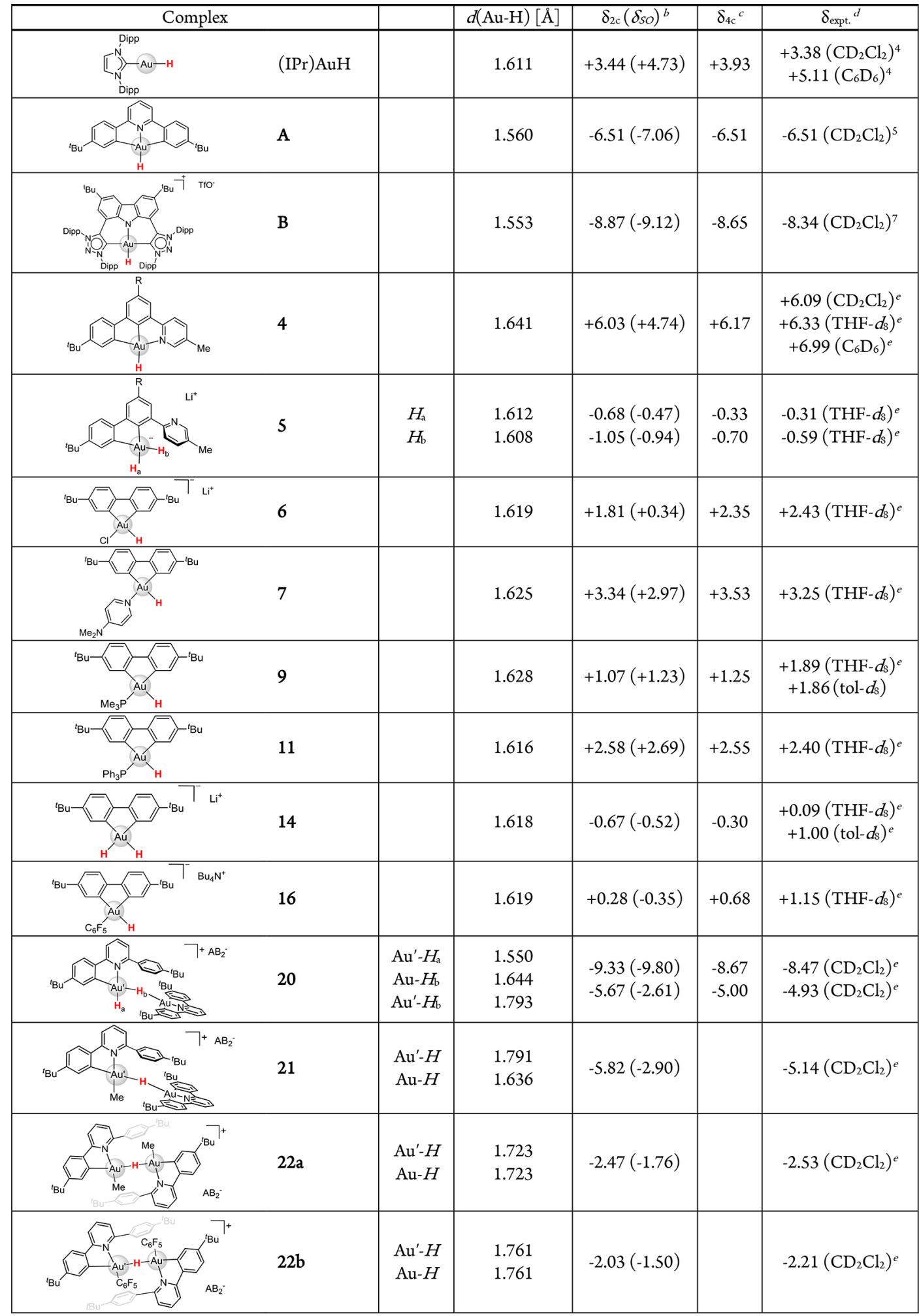

${ }^{a}$ In ppm vs TMS. All calculations done for PBE0-D3(BJ)/ECP/def2-TZVP optimized structures (see SI). ${ }^{b}$ Chemical shifts computed at the $2 \mathrm{c}-$ ZORA(SO)/PBE0-XC/TZ2P level; SO-induced contributions to hydride shifts, $\delta_{\mathrm{SO}}$, are given in parentheses. ${ }^{c}$ For comparative purposes, the hydride shifts were also computed at the four-component, fully relativistic 4c-mDKS/PBE0/Dyall-VDZ/IGLO-II level. ${ }^{d}$ Solvents used in NMR measurements are given in parentheses. ${ }^{e}$ This work.

distances (Figure 3a), which suggests the potential use of ${ }^{1} \mathrm{H}$ NMR spectroscopy in refining precise hydride positions and explains, inter alia, the striking downfield ${ }^{1} \mathrm{H}$ shift in
$\left(\mathrm{C}^{\wedge} \mathrm{C}^{\wedge} \mathrm{N}\right) \mathrm{AuH}(4)$. Interestingly, complexes in Table 1 with longer and more ionic $\mathrm{Au}-\mathrm{H}$ bonds feature high-frequency (downfield) hydride shifts, which contrasts with organic $\mathrm{C}-\mathrm{H}$ 

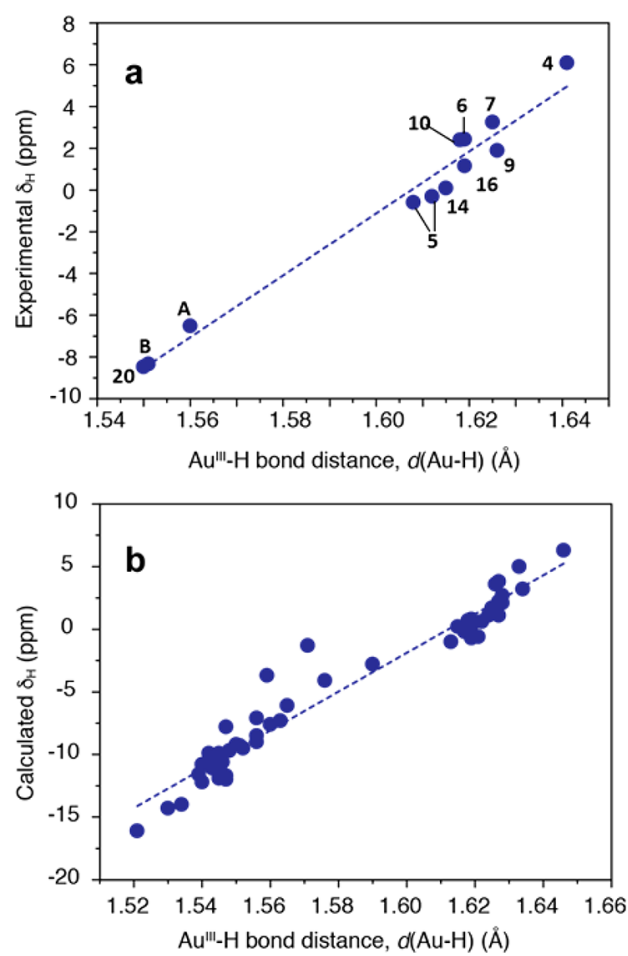

Figure 3. Dependence of experimental (a) and computed (b) ${ }^{1} \mathrm{H}$ NMR chemical shifts of terminal $\mathrm{Au}-H$ hydride atoms (in ppm vs TMS) on the $\mathrm{Au}-\mathrm{H}$ bond-length ( $\AA$ ) for gold(III) complexes with diverse ligand environments. The $\mathrm{Au}-\mathrm{H}$ bond distances were obtained computationally at the DFT (PBE0-D3(BJ)/def2-TZVP) level. (b) contains both experimentally characterized and hypothetical $\mathrm{Au}(\mathrm{III})$ hydride complexes (cf. Table 1 and Tables S2-S4 in SI for numerical data). Linear regressions: (a) $\delta_{\mathrm{H}}=149.67 d(\mathrm{Au}-\mathrm{H})$ $-240.57, R^{2}=0.970 ;(\mathrm{b}) \delta_{\mathrm{H}}=155.1 d(\mathrm{Au}-\mathrm{H})-249.97, R^{2}=0.950$.

compounds. ${ }^{33}$ To explore the generality of the linear $\delta\left({ }^{1} \mathrm{H}\right)$ vs $\mathrm{d}(\mathrm{Au}-\mathrm{H}$ ) relationship (Figure 3) and to understand the trends in light of electronic structure, a more thorough analysis of ${ }^{1} \mathrm{H}$ hydride shifts for a larger set of $\mathrm{Au}$ (III) hydrides was performed (see Table 1 and Tables S1-S4 in the SI for numeric data).

Decomposition of the computed ${ }^{1} \mathrm{H}$ shieldings into diamagnetic, paramagnetic and spin-orbit contributions shows that the trends in isotropic hydride shifts are dominated by the $\delta_{\text {SO }}$ term (Table 1 and Tables S1-S4 in the SI). Artificial elongation/shortening of $\mathrm{Au}-\mathrm{H}$ bonds by a value of $0.05 \AA$ from their optimized values in selected gold(III) hydrides causes only a small change in ${ }^{1} \mathrm{H}$ hydride shifts $(<1 \mathrm{ppm}$, data not shown), and thus the surprisingly good correlation between $\delta\left({ }^{1} \mathrm{H}\right)$ and $\mathrm{d}(\mathrm{Au}-\mathrm{H})$ has an indirect rather than direct origin. ${ }^{20 \mathrm{c}}$ The opposite sign of the ${ }^{1} \mathrm{H}$ hydride shifts of the coordination isomers $\left(\mathrm{C}^{\wedge} \mathrm{C}^{\wedge} \mathrm{N}\right) \mathrm{AuH}$ and $\left(\mathrm{C}^{\wedge} \mathrm{N}^{\wedge} \mathrm{C}\right) \mathrm{AuH}$ should thus be attributed to different electronic structures (cf. Figure 4) and is rationalized below in terms of molecular orbitals contributing dominantly to $\delta_{\text {SO }}$.

Analysis of the $\delta_{\mathrm{SO}}$ contributions at the 2c-ZORA level show that the hydride deshielding in $\left(\mathrm{C}^{\wedge} \mathrm{C}^{\wedge} \mathrm{N}\right) \mathrm{AuH}$, with the strong $\mathrm{C}$-anionic trans ligand, is dominated by two spinors, HOMO-1 and HOMO-3, both composed from the $\sigma(\mathrm{Au}-$ $\mathrm{H}$ )-type SR HOMO-1 (with an appreciable gold $6 \mathrm{p}$ character) and a primarily ligand-centered $\pi$-type orbital with little metal character, SR HOMO-3 (note that both the occupied MOs are magnetically coupled mainly with an antibonding $\sigma^{*}(\mathrm{Au}-\mathrm{H})$-type orbital, LUMO+3). Since "shielding" $\mathrm{Au}\left(\mathrm{d}_{\pi}\right)$-type MOs (SR HOMO-8, SR HOMO10) lie energetically far below the $\sigma(\mathrm{Au}-\mathrm{H}) \mathrm{MO}$ (by more than $2 \mathrm{eV}$ ), these two types of scalar relativistic MOs do not mix with each other upon inclusion of SO coupling, that hinders hydride shielding and results in the high-frequency hydride shift. In contrast, the ${ }^{1} \mathrm{H}$ shielding for the $\left(\mathrm{C}^{\wedge} \mathrm{N}^{\wedge} \mathrm{C}\right) \mathrm{AuH}$ complex, bearing a weak trans $\mathrm{N}$-donor ligand, is dominated by magnetic couplings between the $\mathrm{Au}\left(\mathrm{d}_{\pi}\right)$-type occupied and $\sigma^{*}(\mathrm{Au}-\mathrm{H})$ virtual MOs. The highest $\sigma(\mathrm{Au}-\mathrm{H})$ type MO is energetically close to the $\mathrm{Au}\left(\mathrm{d}_{\pi}\right)$ orbitals, with $\Delta E$ $\sim 0.5 \mathrm{eV}$, and the deshielding effect of the former diminishes upon $\mathrm{SO}$ mixing with $\mathrm{Au}\left(\mathrm{d}_{\pi}\right)$-based MOs. ${ }^{34}$

As the comparison between the tethered $\left(\mathrm{C}^{\wedge} \mathrm{C}^{\wedge} \mathrm{N}\right)$ and nontethered $\left(\mathrm{C}^{\wedge} \mathrm{C}\right)(\mathrm{N})$ ligand systems in complexes 4 and 7 shows, the steric constraint imposed by the $C^{\wedge} C^{\wedge} N$ pincer ligand also has an important effect. In $\mathrm{C}^{\wedge} \mathrm{C}^{\wedge} \mathrm{N}$ the transinfluence of $\mathrm{C}$ is increased, leading to a significant lengthening of the $\mathrm{Au}-\mathrm{H}$ bond ( $1.641 \AA$ in 4 vs $1.625 \AA$ in 7 ) and a further deshielding of the hydride NMR resonance by about 3 ppm.

Theoretical papers relating ${ }^{1} \mathrm{H}$ NMR hydride shifts as a function of the trans ligand strength have appeared very recently. ${ }^{20 c, 21,22 b}$ However, the influence of ligands in cisposition has so far not been explored. Since in square-planar complexes both cis and trans effects are operative, we performed calculations for three series: trans-[HAu$\left.\left(\mathrm{C}_{6} \mathrm{H}_{5}\right)_{2} \mathrm{~L}\right]^{q}$, cis- $[\mathrm{HAu}(\mathrm{bph}) \mathrm{L}]^{q}$ and cis-[HAu(ppy)L $]^{q+1}$ (bph $=2,2^{\prime}$-biphenyl dianion, ppy $=2$-phenylpyridine anion; $q=0$ or -1 ) in order to study the influences of cis and trans ligands separately for a wide range of common $\sigma$-donor and $\pi$ acceptor ligands (see SI, Tables S2-S4). The ligand effects on the ${ }^{1} \mathrm{H}$ hydride shifts are depicted in Figure 5.

Trans-ligands produce chemical shift changes that are roughly four times larger than cis-ligand effects, consistent with the much larger variation in $\mathrm{Au}-\mathrm{H}$ distances in the trans case and the strikingly different ordering and relative energies of $\sigma(\mathrm{Au}-\mathrm{H})$-type and $\mathrm{Au}\left(\mathrm{d}_{\pi}\right)$ orbitals. The influence of trans ligands on the ${ }^{1} \mathrm{H}$ shift spans about $22.5 \mathrm{ppm}$, with $\mathrm{H}_{2} \mathrm{O}$ as the weakest donor investigated here showing the highest SO shielding contribution, and $\mathrm{SiH}_{3}{ }^{-}$the highest $\mathrm{SO}$ deshielding. Hydride shifts and $\mathrm{Au}-\mathrm{H}$ bond-lengths in gold(III) complexes follow a trend similar to the one observed for linear LAu ${ }^{\mathrm{I}} \mathrm{H}$ hydrides (see SI, Figure S51 and Tables S1 and S2), with the ${ }^{1} \mathrm{H}$ shifts in the $\mathrm{Au}(\mathrm{III})$ series being systematically shifted upfield. ${ }^{35}$

Ligands in cis-positions have a weaker influence on hydride shifts (spanning about $6 \mathrm{ppm}$ ) but show the opposite trend: the weakest $\sigma$-donors (and strongest $\pi$-acceptors) exhibit the highest deshielding (the most positive ${ }^{1} \mathrm{H}$ hydride shifts). As demonstrated for the cis- $[\mathrm{HAu}(\mathrm{bph}) \mathrm{L}]^{q}$ series with $\mathrm{L}=\mathrm{NH}_{3}$, $\mathrm{PH}_{3}, \mathrm{CH}_{3}$ and $\mathrm{SiH}_{3}{ }^{-}$(cf. Figure 5), the cis ligand influence has the same qualitative explanation as postulated for the trans-influence above, but ligands with stronger trans-influence located in the cis-position decrease the energy gap between the highest-lying $\sigma(\mathrm{Au}-\mathrm{H})$ bonding $\mathrm{MO}$ and $\mathrm{Au}\left(\mathrm{d}_{\pi}\right)$-based $\mathrm{MO}$, just the opposite of what is seen for the trans-influence (see SI, Figures S52-S53).

According to the data for the cis- $[\mathrm{HAu}(\mathrm{bph}) \mathrm{L}]^{q}$ and cis$[\mathrm{HAu}(\mathrm{ppy}) \mathrm{L}]^{q+1}$ series, the order of increasing cis ligand influence depends also on the trans ligand. However, in general the strongest cis-influence (reflected in the longest 

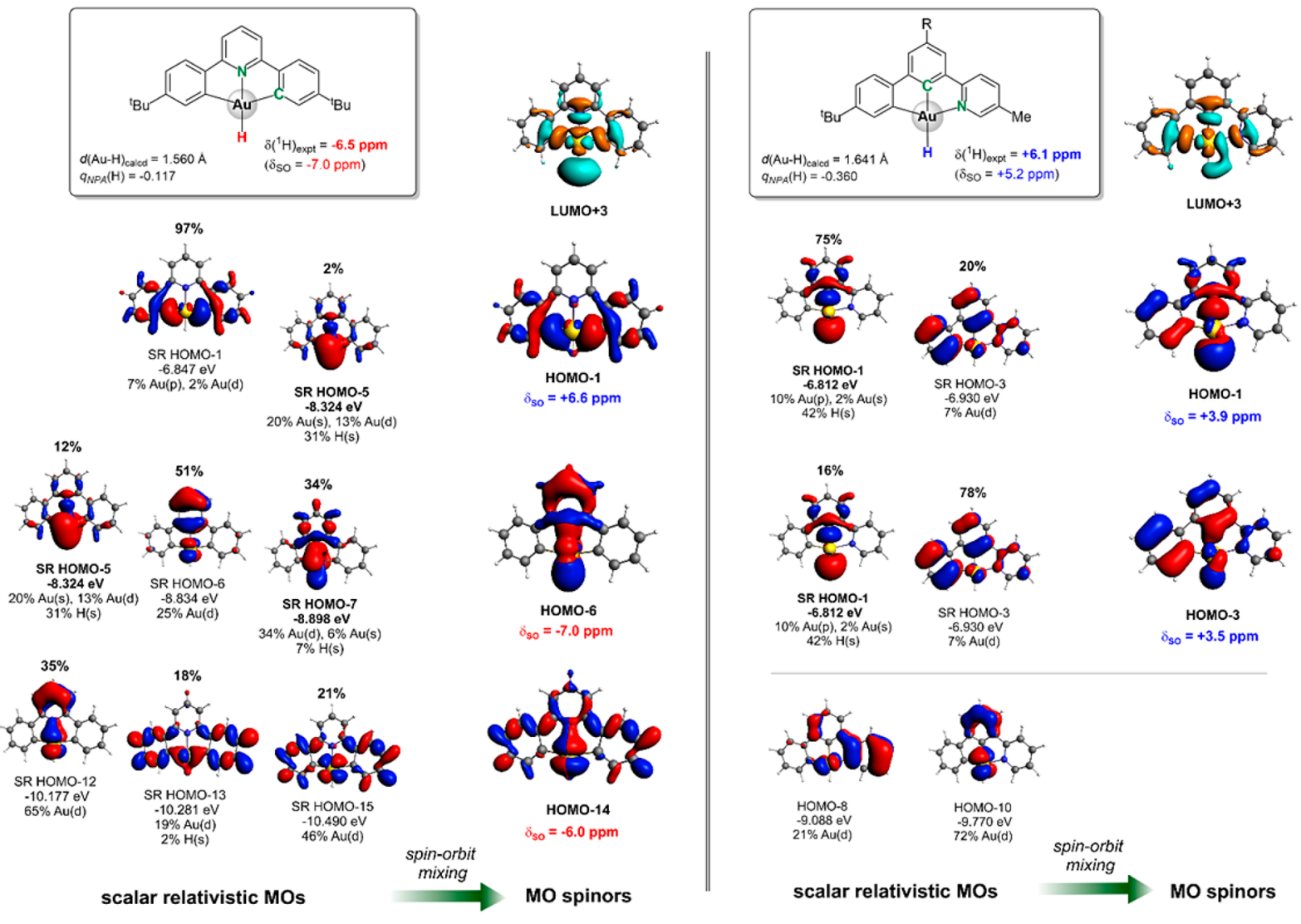

Figure 4. Relevant frontier MOs at scalar-relativistic (SR) level and their mixing to two-component spinors responsible for the overall differences in the ${ }^{1} \mathrm{H}$ hydride shifts of $\left(\mathrm{C}^{\wedge} \mathrm{N}^{\wedge} \mathrm{C}\right) \mathrm{AuH}$ (left) and $\left(\mathrm{C}^{\wedge} \mathrm{C}^{\wedge} \mathrm{N}\right) \mathrm{AuH}$ (right). Only one of two degenerate spinors is shown. The corresponding MOs are shown as isosurface plots $(0.03 \mathrm{au})$, with the hydride ligand generally being placed at the bottom. The mixing percentage of SR MOs in spinors is indicated above the corresponding SR MOs.

$\mathrm{Au}-\mathrm{H}$ bonds and the most downfield ${ }^{1} \mathrm{H}$ shifts) is observed for neutral weak $\sigma$-donors (such as $\mathrm{S}, \mathrm{N}$ and O-based ligands) and $\mathrm{CO}$, while anionic ligands exert the weakest cis-influence, consistent with our experimental NMR data collected in Table 1.

To conclude, the observed correlation between measured ${ }^{1} \mathrm{H}$ hydrides shifts and $\mathrm{Au}-\mathrm{H}$ bond-lengths has an indirect origin, but works surprisingly well for a wider set of studied mononuclear $\mathrm{Au}(\mathrm{III})$ hydrides (Figure 3). This can be attributed to decisive SO-shift contribution and only marginal changes in paramagnetic shielding. Since $\mathrm{Au}-\mathrm{H}$ distances correlate roughly with QTAIM delocalization indices of the $\mathrm{Au}-\mathrm{H}$ bond, a reasonable relationship is also established between ${ }^{1} \mathrm{H}$ NMR hydrides shifts and $\mathrm{Au}-\mathrm{H}$ bond covalency (see Figure 6): the more ionic the $\mathrm{Au}-\mathrm{H}$ bond, the more positive is the hydride shift. ${ }^{36,37}$ Note that the differences in $\mathrm{Au}-\mathrm{H}$ bond covalency could also explain the similar reactivities of gold(III) hydrides with $\mathrm{C}$-anionic trans ligands (with $\delta_{\mathrm{H}}$ ranging from -0.6 to $+7.0 \mathrm{ppm}$ ) and of gold(I) hydride (IPr)AuH $\left(\delta_{\mathrm{H}}=3.38 \mathrm{ppm} / \mathrm{CD}_{2} \mathrm{Cl}_{2}\right)$ toward alkynes: both these compound types insert DMAD but not less activated alkynes, whereas the gold(III) pincer hydride $\left(\mathrm{C}^{\wedge} \mathrm{N}^{\wedge} \mathrm{C}\right) \mathrm{AuH}\left(\delta_{\mathrm{H}}=-6.51 \mathrm{ppm} / \mathrm{CD}_{2} \mathrm{Cl}_{2}\right)$ with a much shorter and more covalent $\mathrm{Au}-\mathrm{H}$ bond behaves differently and adopts a different mechanism.

\section{CONCLUSIONS}

In summary, this work shows that a rather diverse range of gold(III) hydride complex types is accessible using $\mathrm{C}^{\wedge} \mathrm{C}$ chelate ligands, and that stabilization by tridentate pincer ligands is neither a requirement nor a guarantee for thermal stability. Suitable combinations of cis and trans donors provide access to the first examples of stable $\mathrm{Au}$ (III) hydrido phosphine complexes, as well as to anionic hydrido halide, hydrido aryl, and even dihydrido complexes. The biphenylbased $\mathrm{C}^{\wedge} \mathrm{C}$ chelate imparts a remarkable stability toward reductive elimination and successfully suppresses $\mathrm{H}-\mathrm{C}$ and even $\mathrm{H}-\mathrm{H}$ coupling. $\mathrm{C}^{\wedge} \mathrm{N}$ chelate complexes derived from protodeauration of $\left(\mathrm{C}^{\wedge} \mathrm{N}^{\wedge} \mathrm{C}\right)$ pincer precursors proved to be a convenient platform for intercepting the first examples of bridging gold(III) hydrides. The chemistry of the new $\mathrm{C}^{\wedge} \mathrm{C}$ and $\mathrm{C}^{\wedge} \mathrm{C}^{\wedge} \mathrm{N}$-based gold hydrides, with strong $\mathrm{C}$-donors trans to $\mathrm{H}$, was found to differ significantly from that of the $\mathrm{C}^{\wedge} \mathrm{N}^{\wedge} \mathrm{C}$ (weak trans donor) coordination isomers; e.g., the former react only with DMAD but not less activated alkyl or aryl acetylenes, while for the latter the opposite is found. Chemical reactivity correlates with the hydride ${ }^{1} \mathrm{H}$ NMR chemical shift, since both are subject to trans and cis ligand effects. On the basis of detailed quantum-chemical calculations and analysis including relativistic spin-orbit coupling effects, a linear relationship could be established between the computed $\mathrm{Au}-\mathrm{H}$ bond distances, the hydridic character of the $\mathrm{Au}-\mathrm{H}$ bond, and the hydride NMR chemical shifts. Strong trans effect ligands, such as $\mathrm{C}^{-}$in $\left(\mathrm{C}^{\wedge} \mathrm{C}^{\wedge} \mathrm{N}\right) \mathrm{AuH}$, raise the 


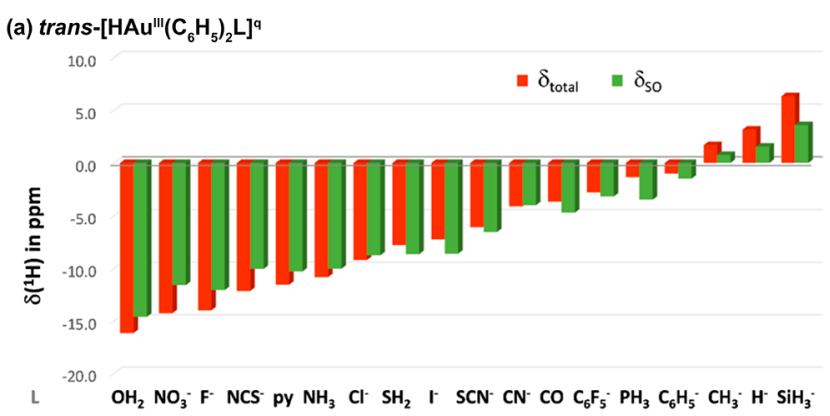

(b) cis-[HAu'"'(bph)L $]^{q}$

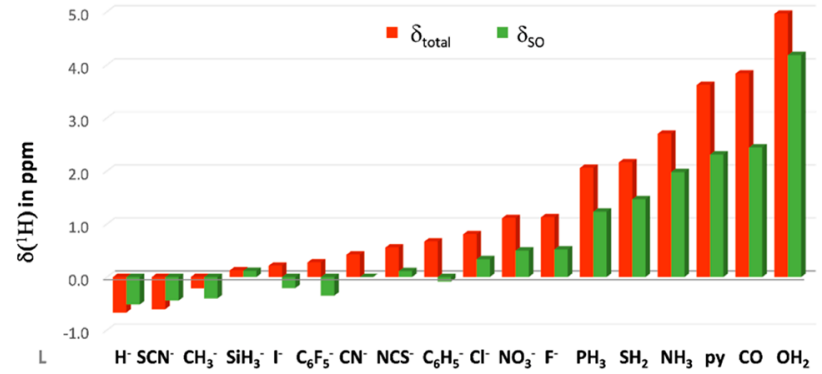

(c) cis-[HAu'"(ppy)L $]^{q+1}$

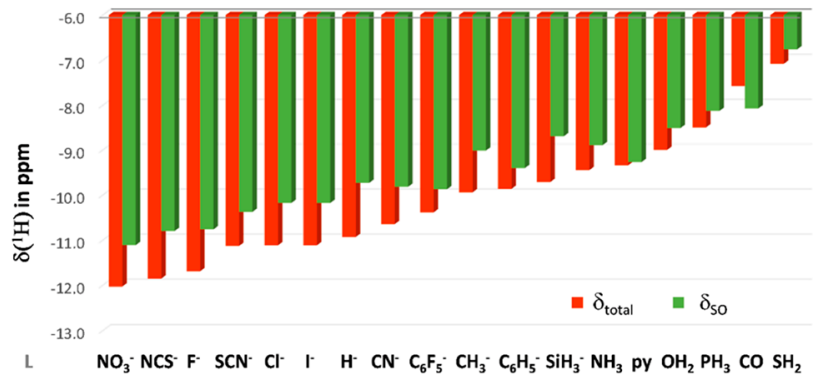

Figure 5. Dependence of the computed ${ }^{1} \mathrm{H}$ hydride shifts $\left(\delta_{\text {total }}\right)$ and spin-orbit-induced shift contributions $\left(\delta_{\mathrm{SO}}\right)$ on $(\mathrm{a})$ the trans ligand $\mathrm{L}$ in the trans-[HAu $\left.{ }^{\mathrm{III}}\left(\mathrm{C}_{6} \mathrm{H}_{5}\right)_{2} \mathrm{~L}\right]^{q}$; (b) the cis-ligand in the cis$\left[\mathrm{HAu}^{\mathrm{III}}(\mathrm{bph}) \mathrm{L}\right]^{q}$; and $(\mathrm{c})$ the cis-ligand in the $c i s-\left[\mathrm{HAu}{ }^{\mathrm{III}}(\mathrm{ppy}) \mathrm{L}\right]^{q+1}$ series (2c-ZORA(SO)/PBE0-XC/TZ2P results; see Tables S2-S4 in SI for numerical data).

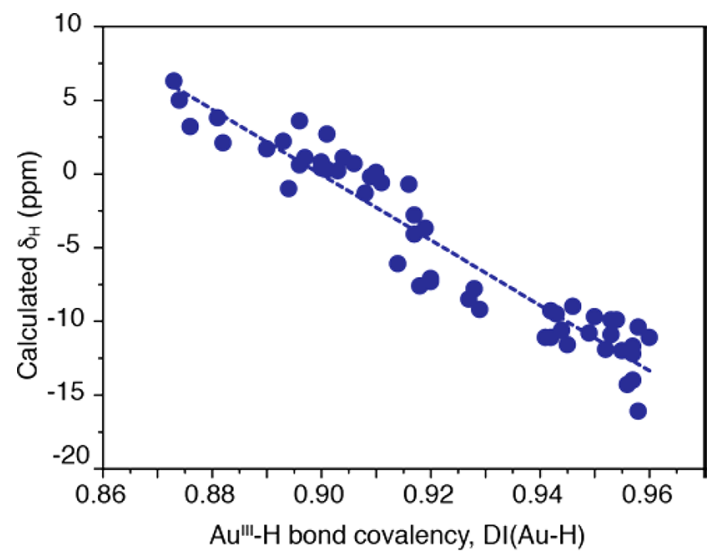

Figure 6. Correlation of computed ${ }^{1} \mathrm{H}$ NMR hydride shifts (in ppm vs TMS) with QTAIM delocalization indices, $\mathrm{DI}(\mathrm{Au}-\mathrm{H})$, as a measure of the bond covalency, for a series of mononuclear $\mathrm{Au}(\mathrm{III})$ hydride complexes (cf. SI, Tables S2-S4 for numerical data).

deshielding $\sigma(\mathrm{Au}-\mathrm{H})$ orbital and increase the energetic separation from orbitals with shielding $\mathrm{Au}\left(\mathrm{d}_{\pi}\right)$-type $\mathrm{MO}$, resulting in deshielding (positive chemical shift), whereas in
$\left(\mathrm{C}^{\wedge} \mathrm{N}^{\wedge} \mathrm{C}\right) \mathrm{AuH} \sigma(\mathrm{Au}-\mathrm{H})$ and $\mathrm{Au}\left(\mathrm{d}_{\pi}\right)$ are close in energy, so that the hydride shift is dominated by the shielding SO contribution. Whereas trans-ligand influence calculated for a sequence of hypothetical complexes cover a range of over 22 $\mathrm{ppm}$, cis-ligand influence is more limited, about $6 \mathrm{ppm}$, although both these effects are mutually interdependent. The effect of cis-ligands follows an approximate inverse order to trans-ligands, with the strongest cis-influence (and the longest $\mathrm{Au}-\mathrm{H}$ bonds) being observed for the weakest neutral $\sigma$ donors. This appears to be the first systematic evaluation of cis-ligand effects on ${ }^{1} \mathrm{H}$ chemical shifts in square-planar $\mathrm{d}^{8}$ systems.

\section{EXPERIMENTAL SECTION}

General Considerations. When required, manipulations were performed using standard Schlenk techniques under dry argon or using a nitrogen-filled MBraun Unilab glovebox equipped with a high capacity recirculator $\left(<1.0 \mathrm{ppm}\right.$ of $\mathrm{O}_{2}$ and $\left.\mathrm{H}_{2} \mathrm{O}\right)$. Argon was purified by passing through columns of supported $\mathrm{P}_{2} \mathrm{O}_{5}$ with moisture indicator and of activated $4 \AA$ molecular sieves. Anhydrous solvents were freshly distilled from the appropriate drying agents and degassed. Triphenylphosphine (99\%), tris( $p$-tolyl)phosphine (98\%), trimethylphosphine (1.0 M in THF), dimethylaminopyridine (DMAP, >99\%), lithium triethylborohydride $(1.0 \mathrm{M}$ in THF), dimethyl acetylenedicarboxylate (DMAD, 99\%) trimethoxysilane (95\%), were obtained by Sigma-Aldrich and dried, when necessary. Solid $\mathrm{LiAlH}_{4}$ was obtained by vacuum-drying a commercial solution in THF (Sigma-Aldrich). $\mathrm{CD}_{2} \mathrm{Cl}_{2}$ (Apollo Scientific), THF- $d_{8}$ and toluene- $d_{8}$ (Fluorochem Ltd.) were freeze-pump-thaw degassed over $\mathrm{CaH}_{2}$, distilled and stored over activated $4 \AA$ molecular sieves. $\mathrm{C}_{6} \mathrm{~F}_{5} \mathrm{Ag}\left(\mathrm{CH}_{3} \mathrm{CN}\right),^{38}\left[\left(\mathrm{C}^{\wedge} \mathrm{C}\right) \mathrm{AuCl}\right]_{2},{ }^{16}\left(\mathrm{C}^{\wedge} \mathrm{C}\right) \mathrm{AuCl}(\mathrm{py})(\mathbf{2}),{ }^{16}$ $\left(\mathrm{C}^{\wedge} \mathrm{N}^{\wedge} \mathrm{C}\right) \mathrm{AuH}^{5},{ }^{5}\left(\mathrm{C}^{\wedge} \mathrm{N}^{\wedge} \mathrm{C}\right) \mathrm{AuMe}^{39},\left(\mathrm{C}^{\wedge} \mathrm{N}^{\wedge} \mathrm{C}\right) \mathrm{AuC}_{6} \mathrm{~F}_{5},{ }^{40}\left[\mathrm{H}\left(\mathrm{OEt}_{2}\right)_{2}\right]-$ $\left[\mathrm{H}_{2} \mathrm{~N}\left\{\mathrm{~B}\left(\mathrm{C}_{6} \mathrm{~F}_{5}\right)_{3}\right\}_{2}\right]^{28}\left(\mathrm{HAB}_{2}\right)$ were synthesized according to literature procedures. Protodeaurated species $\left[\left(\mathrm{C}^{\wedge} \mathrm{N}-\mathrm{CH}\right) \mathrm{AuMe}\right]$ $\left[\mathrm{AB}_{2}\right](3 \mathbf{a})$ and $\left[\left(\mathrm{C}^{\wedge} \mathrm{N}-\mathrm{CH}\right) \mathrm{AuC}_{6} \mathrm{~F}_{5}\right]\left[\mathrm{AB}_{2}\right](\mathbf{3} \mathbf{b})$ were generated within the glovebox, as reported previously. ${ }^{17}$

Low-temperature in situ NMR experiments were performed under anhydrous and anaerobic conditions by using screw cap NMR tubes equipped with a PTFE septum. In a typical experiment, the gold precursor was loaded into the NMR tube inside a glovebox and dissolved in the appropriate solvent. Successively, the sample was inserted into a cold bath at $195 \mathrm{~K}$ and the desired reagents were injected through the septum by using a micrometric gastight syringe. The cold sample was then inserted into the precooled NMR probe and characterized. ${ }^{1} \mathrm{H},{ }^{1} \mathrm{H}$ PGSE, ${ }^{1} \mathrm{H}$ inversion recovery, ${ }^{19} \mathrm{~F}$, ${ }^{13} \mathrm{C}\left\{{ }^{1} \mathrm{H}\right\}$, ${ }^{1} \mathrm{H}$ COSY, ${ }^{1} \mathrm{H}$ NOESY, ${ }^{1} \mathrm{H},{ }^{13} \mathrm{C}$ HMQC, and ${ }^{1} \mathrm{H},{ }^{13} \mathrm{C}$ HMBC NMR experiments were recorded on a Bruker DPX-300 spectrometer equipped with a ${ }^{1} \mathrm{H}, \mathrm{BB}$ smartprobe and Z-gradients. ${ }^{1} \mathrm{H}$ NMR spectra were referenced to the residual protons of the deuterated solvent. ${ }^{13} \mathrm{C}$ NMR spectra were referenced to the $\mathrm{D}$ coupled ${ }^{13} \mathrm{C}$ signals of the solvent. ${ }^{19} \mathrm{~F}$ NMR spectra were referenced to an external standard of $\mathrm{CFCl}_{3} .{ }^{31} \mathrm{P}$ NMR spectra were referenced to an external standard of $\mathrm{H}_{3} \mathrm{PO}_{4} 85 \%$. Photoisomerization experiments were performed by using a Blak-Ray B-100 Series high-powered UV lamp and by irradiating solutions contained in JYoung NMR tubes.

Synthesis and Characterization of New Gold Precursors. $(C \wedge C \wedge N) A u C l$ (1). This complex was synthesized in $89 \%$ yield by following literature procedures, ${ }^{15}$ using 2-bromo-5-methylpyridine as ligand precursor. ${ }^{1} \mathrm{H}$ NMR $\left(300.13 \mathrm{MHz}, \mathrm{CD}_{2} \mathrm{Cl}_{2}, 297 \mathrm{~K}\right.$, $J$ values in $\mathrm{Hz}) \delta 8.78($ brs, $1 \mathrm{H}, \mathrm{H1}), 7.80\left(\mathrm{~d},{ }^{4} J_{\mathrm{HH}}=1.6, \mathrm{H} 16\right), 7.72(\mathrm{AB}$ system, $2 \mathrm{H}, \mathrm{H} 3+\mathrm{H} 4), 7.61\left(\mathrm{~d},{ }^{3} \mathrm{~J}_{\mathrm{HH}}=8.4,2 \mathrm{H}, \mathrm{H} 19\right), 7.52\left(\mathrm{~d},{ }^{3} \mathrm{~J}_{\mathrm{HH}}=\right.$ 8.4, 2H, H20), $7.39\left(\mathrm{~d},{ }^{4} J_{\mathrm{HH}}=1.5, \mathrm{H} 7\right), 7.34\left(\mathrm{~d},{ }^{4} J_{\mathrm{HH}}=1.5, \mathrm{H} 9\right)$, 7.23 (AB system, 2H, H13+H14), $2.33(\mathrm{~s}, 3 \mathrm{H}, \mathrm{Me}), 1.38(\mathrm{~s}, 9 \mathrm{H}$, $\left.\mathrm{C}(21) \mathrm{CMe}_{3}\right), 1.32 \mathrm{ppm}\left(\mathrm{s}, 9 \mathrm{H}, \mathrm{C}(15) \mathrm{CMe}_{3}\right) .{ }^{13} \mathrm{C}\left\{{ }^{1} \mathrm{H}\right\}$ NMR (75.47 $\left.\mathrm{MHz}, \mathrm{CD}_{2} \mathrm{Cl}_{2}, 297 \mathrm{~K}\right) \delta 164.7(\mathrm{~s}, \mathrm{C} 11), 160.1(\mathrm{~s}, \mathrm{C} 5), 151.0(\mathrm{~s}$, C15), 150.8 (s, C21+C12), 150.4 (s, C17), 149.4 (s, C10), 148.7 (s, C1), 141.2 (s, C3+C6), 140.0 (s, C8), 137.9 (s, C18), 135.2 (s, C2), 
131.4 (s, C16), 126.9 (s, C19), 125.8 (s, C20), 124.4 (s, C14), 121.5 (s+s, C13+C9), $120.2(\mathrm{~s}, \mathrm{C} 7), 119.8(\mathrm{~s}, \mathrm{C} 4), 35.0\left(\mathrm{~s}, \mathrm{C}(15) \mathrm{CMe}_{3}\right)$, 34.5 (s, $\left.\mathrm{C}(21) \mathrm{CMe}_{3}\right), 31.1$ (s, $\mathrm{C}(15) \mathrm{CMe}_{3}$ or $\left.\mathrm{C}(21) \mathrm{CMe}_{3}\right) 31.0$ (s, $\mathrm{C}\left(21 \mathrm{CMe}_{3}\right.$ or $\left.\mathrm{C}(15) \mathrm{CMe}_{3}\right), 18.2 \mathrm{ppm}$ (s, Me). Calcd for $\mathrm{C}_{32} \mathrm{H}_{33} \mathrm{AuNCl}$ (found) C, 57.86 (57.69); H, 5.01 (4.94); N, 2.11 (2.18) \%.

$(\mathrm{C} \wedge \mathrm{C}) \mathrm{AuCl}\left(\mathrm{Ptol}_{3}\right) \cdot\left[\left(\mathrm{C}^{\wedge} \mathrm{C}\right) \mathrm{AuCl}\right]_{2}(200 \mathrm{mg}, 0.2 \mathrm{mmol})$ was stirred in dichloromethane $(30 \mathrm{~mL})$ with excess tris-para-tolylphosphine $(120 \mathrm{mg}, 0.4 \mathrm{mmol})$ until a clear solution was obtained. The reaction mixture was filtered through Celite and the solvent removed under reduced pressure. Hexane was added, the mixture sonicated briefly and the white solid powder filtered and washed with hexane. It was then recrystallized from $\mathrm{Et}_{2} \mathrm{O} /$ hexane to afford $\left(\mathrm{C}^{\wedge} \mathrm{C}\right) \mathrm{AuCl}\left(\mathrm{Ptol}_{3}\right)$ $(290 \mathrm{mg}, 90 \%) .{ }^{1} \mathrm{H}$ NMR $\left(300.13 \mathrm{MHz}, \mathrm{CD}_{2} \mathrm{Cl}_{2}, 297 \mathrm{~K}, J\right.$ values in Hz) $\delta 8.38\left(\mathrm{dd},{ }^{4} J_{\mathrm{HP}}=9.5,{ }^{4} J_{\mathrm{HH}}=1.8,1 \mathrm{H}, \mathrm{H} 2\right), 7.53-7.59(\mathrm{~m}, 6 \mathrm{H}, o-$ tol $\left._{3}\right), 7.24-7.32\left(\mathrm{~m}, 8 \mathrm{H}, m-\right.$ tol $\left._{3}+\mathrm{H} 5+\mathrm{H}^{\prime}\right), 7.19\left(\mathrm{dd},{ }^{3} J_{\mathrm{HH}}=8.0{ }^{4} J_{\mathrm{HH}}\right.$ $=1.6,1 \mathrm{H}, \mathrm{H} 4), 7.03\left(\mathrm{dd},{ }^{3} J_{\mathrm{HH}}=8.0{ }^{4} \mathrm{~J}_{\mathrm{HH}}=1.8,1 \mathrm{H}, \mathrm{H} 4^{\prime}\right), 6.92(\mathrm{dd}$, $\left.{ }^{4} J_{\mathrm{HP}}=3.4,{ }^{4} J_{\mathrm{HH}}=1.8,1 \mathrm{H}, \mathrm{H} 2{ }^{\prime}\right), 2.39(\mathrm{~s}, 9 \mathrm{H}, \mathrm{Me}), 1.31(\mathrm{~s}, 9 \mathrm{H}$, $\mathrm{CMe}_{3}$ ), $0.67 \mathrm{ppm}\left(\mathrm{s}, 9 \mathrm{H}, \mathrm{CMe}_{3}{ }^{\prime}\right) .{ }^{31} \mathrm{P}\left\{{ }^{1} \mathrm{H}\right\} \mathrm{NMR}(121.49 \mathrm{MHz}$, $\left.\mathrm{CD}_{2} \mathrm{Cl}_{2}, 297 \mathrm{~K}\right) 40.2$ ppm. ${ }^{13} \mathrm{C}\left\{{ }^{1} \mathrm{H}\right\} \operatorname{NMR}\left(75.47 \mathrm{MHz}, \mathrm{CD}_{2} \mathrm{Cl}_{2}, 297\right.$ $\mathrm{K}, J$ values in $\mathrm{Hz}) \delta 166.1\left(\mathrm{~d},{ }^{2} J_{\mathrm{CP}}=129.6, \mathrm{C} 1\right), 154.0\left(\mathrm{~d},{ }^{2} J_{\mathrm{CP}}=7.3\right.$, $\left.\mathrm{C1}^{\prime}\right), 151.3\left(\mathrm{~d},{ }^{3} J_{\mathrm{CP}}=4.5, \mathrm{C}^{\prime}\right), 149.7-149.6(\mathrm{~m}, \mathrm{C} 6+\mathrm{C} 3), 149.2(\mathrm{~d}$, $\left.{ }^{4} J_{\mathrm{CP}}=2.7, \mathrm{C}_{3}\right), 142.3\left(\mathrm{~d},{ }^{4} J_{\mathrm{CP}}=2.4, \mathrm{CMe} \mathrm{tol}_{3}\right), 135.1\left(\mathrm{~d},{ }^{2} J_{\mathrm{CP}}=11.5\right.$, $o$-tol $\left.{ }_{3}\right), 134.2\left(\mathrm{~d},{ }^{3} J_{\mathrm{CP}}=10.2, \mathrm{C} 2{ }^{\prime}\right), 130.5\left(\mathrm{~d},{ }^{3} J_{\mathrm{CP}}=1.8, \mathrm{C} 2\right), 129.4$ $\left(\mathrm{d},{ }^{4} J_{\mathrm{CP}}=11.2, m\right.$-tol $\left.{ }_{3}\right), 125.1\left(\mathrm{~d},{ }^{1} J_{\mathrm{CP}}=51.0\right.$, ipso-C tol $\left._{3}\right), 124.5(\mathrm{br}$ s, $\mathrm{C}_{4}$ ), 123.8 (s, C4'), 120.7 (s, $\left.\mathrm{C}_{5}{ }^{\prime}\right), 120.4\left(\mathrm{~d},{ }^{4} J_{\mathrm{CP}}=7.6, \mathrm{C} 5\right), 35.3$ (s, $\left.\mathrm{CMe}_{3}\right), 35.4\left(\mathrm{~s}, \mathrm{CMe}_{3}{ }^{\prime}\right), 31.2\left(\mathrm{~s}, \mathrm{CMe}_{3}\right), 30.4\left(\mathrm{~s}, \mathrm{CMe}_{3}{ }^{\prime}\right), 21.2$ ppm (s, Me tol ${ }_{3}$ ). Calcd for $\mathrm{C}_{41} \mathrm{H}_{45} \mathrm{AuClP}$ (found) C, 61.44 (61.36); $\mathrm{H}, 5.66(5.67) \%$.

$(\mathrm{C} \wedge \mathrm{C}) \mathrm{AuCl}\left(\mathrm{PMe}_{3}\right) . \quad\left[\left(\mathrm{C}^{\wedge} \mathrm{C}\right) \mathrm{AuCl}\right]_{2} \quad(270 \mathrm{mg}, 0.27 \mathrm{mmol})$ was stirred in THF $(10 \mathrm{~mL})$ under Ar. Excess trimethylphosphine $(0.5$ $\mathrm{mL}$ of $1 \mathrm{M}$ solution in THF, $0.5 \mathrm{mmol}$ ) was added at $25^{\circ} \mathrm{C}$ and the mixture was stirred until a clear solution was obtained. The reaction mixture was filtered through Celite and the solvent removed under reduced pressure. Hexane was added, the mixture sonicated briefly and the white solid powder filtered and washed with hexane to afford $\left(\mathrm{C}^{\wedge} \mathrm{C}\right) \mathrm{AuCl}\left(\mathrm{PMe}_{3}\right) \quad(250 \mathrm{mg}, 81 \%) .{ }^{1} \mathrm{H}$ NMR (300.13 $\mathrm{MHz}$, $\mathrm{CD}_{2} \mathrm{Cl}_{2}, 297 \mathrm{~K}, J$ values in $\left.\mathrm{Hz}\right) \delta 8.29(\mathrm{br} \mathrm{d}, 1 \mathrm{H}, \mathrm{H} 2), 7.43-7.13$ (br m, 5H, H4+H4 $\left.{ }^{\prime}+\mathrm{H} 5+\mathrm{H}^{\prime}+\mathrm{H} 2^{\prime}\right), 1.85\left(\mathrm{~d},{ }^{2} J_{\mathrm{HP}}=10.8, \mathrm{PMe}_{3}\right)$, $1.34 \mathrm{ppm}\left(\mathrm{s}, 18 \mathrm{H}, \mathrm{CMe}_{3}+\mathrm{CMe}_{3}{ }^{\prime}\right) .{ }^{31} \mathrm{P}\left\{{ }^{1} \mathrm{H}\right\}$ NMR $(121.49 \mathrm{MHz}$, $\left.\mathrm{CD}_{2} \mathrm{Cl}_{2}, 297 \mathrm{~K}\right) 3.4 \mathrm{ppm} .{ }^{13} \mathrm{C}\left\{{ }^{1} \mathrm{H}\right\}$ NMR $\left(75.47 \mathrm{MHz}, \mathrm{CD}_{2} \mathrm{Cl}_{2}, 297\right.$ $\mathrm{K}, J$ values in $\mathrm{Hz}) \delta 165.2\left(\mathrm{~d},{ }^{2} J_{\mathrm{CP}}=138.4, \mathrm{C} 1\right), 153.2\left(\mathrm{br} \mathrm{s}, \mathrm{Cl}^{\prime}\right)$, $151.6\left(\mathrm{~s}, \mathrm{C6}^{\prime}\right), 149.6\left(\mathrm{~m}, \mathrm{C} 3+\mathrm{C}^{\prime}\right), 149.2$ (s, C6), 130.0 (s, $\left.\mathrm{C} 2+\mathrm{C}^{\prime}\right), 124.6\left(\mathrm{~s}, \mathrm{C} 4\right.$ or $\left.\mathrm{C}^{\prime}\right), 124.4\left(\mathrm{~s}, \mathrm{C}^{\prime}\right.$ or $\left.\mathrm{C} 4\right), 121.5\left(\mathrm{~s}, \mathrm{C}^{\prime}\right)$, $120.4\left(\mathrm{brd},{ }^{5} \mathrm{~J}_{\mathrm{CP}}=6.6, \mathrm{C} 5\right), 35.2\left(\mathrm{~s}, \mathrm{CMe}_{3}\right.$ or $\left.\mathrm{CMe}_{3}{ }^{\prime}\right), 31.2(\mathrm{~s}+\mathrm{s}$, $\left.\mathrm{CMe}_{3}+\mathrm{CMe}_{3}{ }^{\prime}\right), 14.2 \mathrm{ppm}\left(\mathrm{d},{ }^{1} J_{\mathrm{CP}}=30.4, \mathrm{PMe}_{3}\right)$. Calcd for $\mathrm{C}_{23} \mathrm{H}_{33} \mathrm{AuClP}$ (found) C, 48.22 (48.43); H, 5.81 (5.89) \%.

$(C \wedge C) A u\left(C_{6} F_{5}\right)(p y) . \mathrm{C}_{6} \mathrm{~F}_{5} \mathrm{Ag}\left(\mathrm{CH}_{3} \mathrm{CN}\right)(93 \mathrm{mg}, 0.3 \mathrm{mmol})$ in $\mathrm{Et}_{2} \mathrm{O}$ $(5 \mathrm{~mL})$ was added to a solution of $2(170 \mathrm{mg}, 0.3 \mathrm{mmol})$ in dichloromethane $(5 \mathrm{~mL})$ in a centrifuge tube, with immediate formation of $\mathrm{AgCl}$. After $5 \mathrm{~min}$, the tube was centrifuged. The clear solution was decanted and the solvent removed under reduced pressure to afford the product as a white solid $(144 \mathrm{mg}, 60 \%) .{ }^{1} \mathrm{H}$ NMR $\left(300.13 \mathrm{MHz}, \mathrm{CD}_{2} \mathrm{Cl}_{2}, 297 \mathrm{~K}, J\right.$ values in $\left.\mathrm{Hz}\right) \delta 8.78\left(\mathrm{~d},{ }^{3} J_{\mathrm{HH}}\right.$ $=5.2,2 \mathrm{H}, o-\mathrm{py}), 8.04\left(\mathrm{t},{ }^{3} J_{\mathrm{HH}}=7.8,1 \mathrm{H}, p\right.$-py), $7.68\left(\mathrm{t},{ }^{3} J_{\mathrm{HH}}=6.7\right.$, $2 \mathrm{H}, m$-py), $7.37\left(\mathrm{~d},{ }^{3} J_{\mathrm{HH}}=8.0,1 \mathrm{H}, \mathrm{H} 5\right), 7.32\left(\mathrm{~d},{ }^{3} J_{\mathrm{HH}}=8.0,1 \mathrm{H}\right.$, $\left.\mathrm{H}^{\prime}\right), 7.18-7.22\left(\mathrm{~m}, 2 \mathrm{H}, \mathrm{H} 4+\mathrm{H} 4^{\prime}\right), 6.84\left(\mathrm{~d},{ }^{4} J_{\mathrm{HH}}=1.2,1 \mathrm{H}, \mathrm{H} 2\right)$, $6.34\left(\mathrm{~d},{ }^{4} \mathrm{~J}_{\mathrm{HH}}=1.2,1 \mathrm{H}, \mathrm{H}^{\prime}\right), 1.50\left(\mathrm{~s}, 9 \mathrm{H}, \mathrm{CMe}_{3}\right), 1.08 \mathrm{ppm}(\mathrm{s}, 9 \mathrm{H}$, $\left.\mathrm{CMe}_{3}{ }^{\prime}\right) \cdot{ }^{19} \mathrm{~F}$ NMR $\left(282 \mathrm{MHz}, \mathrm{CD}_{2} \mathrm{Cl}_{2}, 297 \mathrm{~K}\right) \delta-120.8(\mathrm{~m}, o-\mathrm{F})$, -159.6 (t, $p$-F), -161.9 (m, $m$-F) ppm. ${ }^{13} \mathrm{C}\left\{{ }^{1} \mathrm{H}\right\}$ NMR $(75.47 \mathrm{MHz}$, $\left.\mathrm{CD}_{2} \mathrm{Cl}_{2}, 297 \mathrm{~K}\right) \delta 151.5$ (s, C1'), 150.1 (s, o-py), 149.9 (s, C1), 149.5 (s, C6+C6'), 144.5 (s, C3+C3'), 140.1 (s, p-py), 132.4 (s, C2), 127.7 (s, C2'), 127.1 (s, m-py), 124.5 (s, C5), 124.1 (s, C5'), 121.1 (s, C4' $), 120.3$ (s, C4), $34.6\left(\mathrm{~s}, \mathrm{CMe}_{3}\right), 34.4\left(\mathrm{~s}, \mathrm{CMe}_{3}{ }^{\prime}\right), 30.92$ (s, $\mathrm{CMe}_{3}$ ), $30.89 \mathrm{ppm}\left(\mathrm{s}, \mathrm{CMe}_{3}{ }^{\prime}\right)$. Calcd for $\mathrm{C}_{31} \mathrm{H}_{2} \mathrm{Au} \mathrm{F}_{5} \mathrm{~N}$ (found) C, 52.6 (51.96); H, 4.13 (4.55); N, 1.98 (2.01)\%.

$\left[{ }^{n} B u_{4} N\right]\left[(C \wedge C) A u C l\left(C_{6} F_{5}\right)\right]$ (15). $\left(C^{\wedge} C\right) A u\left(C_{6} F_{5}\right)($ py) $(50 \mathrm{mg}, 71$ $\mu \mathrm{mol})$ was stirred in dichloromethane $(5 \mathrm{~mL})$ in the presence of excess tetrabutylammonium chloride $(30 \mathrm{mg}, 0.1 \mathrm{mmol})$ for $1 \mathrm{~h}$. The solvent was removed under reduced pressure. Dichloromethane (5
$\mathrm{mL}$ ) was added and the mix stirred again for $1 \mathrm{~h}$. The solvent was removed under reduced pressure. The residue was sonicated in $\mathrm{Et}_{2} \mathrm{O}$ and the white powder filtered to yield 15 (45 mg, 98\%). ${ }^{1} \mathrm{H}$ NMR $\left(300.13 \mathrm{MHz}, \mathrm{CD}_{2} \mathrm{Cl}_{2}, 297 \mathrm{~K}, J\right.$ values in $\left.\mathrm{Hz}\right) \delta 8.24\left(\mathrm{~d},{ }^{4} J_{\mathrm{HH}}=2.0\right.$, $1 \mathrm{H}, \mathrm{H} 2), 7.25\left(\mathrm{~d},{ }^{3} J_{\mathrm{HH}}=8.0,1 \mathrm{H}, \mathrm{H} 5\right), 7.24\left(\mathrm{~d},{ }^{3} J_{\mathrm{HH}}=8.0,1 \mathrm{H}\right.$, $\left.\mathrm{H}^{\prime}\right), 7.12\left(\mathrm{dd},{ }^{3} J_{\mathrm{HH}}=8.0,{ }^{4} J_{\mathrm{HH}}=1.9,1 \mathrm{H}, \mathrm{H} 4\right), 7.08\left(\mathrm{dd},{ }^{3} J_{\mathrm{HH}}=\right.$ $\left.8.0,{ }^{4} J_{\mathrm{HH}}=1.9,1 \mathrm{H}, \mathrm{H} 4^{\prime}\right), 6.81\left(\mathrm{~d},{ }^{4} J_{\mathrm{HH}}=1.6,1 \mathrm{H}, \mathrm{H} 2^{\prime}\right), 2.99-3.06$ $\left(\mathrm{m}, 8 \mathrm{H}, \mathrm{CH}_{3}\left(\mathrm{CH}_{2}\right)_{2} \mathrm{CH}_{2} \mathrm{~N}\right), 1.41-1.52(\mathrm{~m}, 8 \mathrm{H}$, $\left.\mathrm{CH}_{3} \mathrm{CH}_{2} \mathrm{CH}_{2} \mathrm{CH}_{2} \mathrm{~N}\right), 1.33\left(\mathrm{~s}, 9 \mathrm{H}, \mathrm{CMe}_{3}\right), 1.26-1.32(\mathrm{~m}, 8 \mathrm{H}$, $\left.\mathrm{CH}_{3} \mathrm{CH}_{2}\left(\mathrm{CH}_{2}\right)_{2} \mathrm{~N}\right), 1.10$ (s, 9H, $\left.\mathrm{CMe}_{3}{ }^{\prime}\right), 0.92 \mathrm{ppm}\left(\mathrm{t},{ }^{3} \mathrm{~J}_{\mathrm{HH}}=7.6\right.$, $\left.12 \mathrm{H}, \mathrm{CH}_{3}\left(\mathrm{CH}_{2}\right)_{3} \mathrm{~N}\right) .{ }^{19} \mathrm{~F}$ NMR $\left(282 \mathrm{MHz}, \mathrm{CD}_{2} \mathrm{Cl}_{2}, 297 \mathrm{~K}\right)-119.6$ (m, o-F), $-162.3(\mathrm{t}, p-\mathrm{F}),-163.2(\mathrm{~m}, m-\mathrm{F})$ ppm. ${ }^{13} \mathrm{C}\left\{{ }^{1} \mathrm{H}\right\}$ NMR $\left(75.47 \mathrm{MHz}, \mathrm{CD}_{2} \mathrm{Cl}_{2}, 297 \mathrm{~K}\right) \delta 151.1\left(\mathrm{~s}, \mathrm{C}^{\prime}\right), 150.2(\mathrm{~s}, \mathrm{C} 2), 149.2$ (s, C5'), 148.7 (s, C5), 131.3 (s, C4'), 130.0 (s, C4), 129.9 (s, C1'), 123.4 (s, C3'), 123.1 (s, C3), 120.3 (s, C6'), 120.1 (s, C1), 119.5 (s, C6), $58.6\left(\mathrm{~s}, \mathrm{CH}_{3}\left(\mathrm{CH}_{2}\right)_{2} \mathrm{CH}_{2} \mathrm{~N}\right), 35.0\left(\mathrm{~s}, \mathrm{CMe}_{3}{ }^{\prime}\right), 34.3\left(\mathrm{~s}, \mathrm{CMe}_{3}\right)$, $31.4\left(\mathrm{~s}, \mathrm{Cl}^{\prime}\right), 30.9$ (s, C8), $23.8\left(\mathrm{~s}, \mathrm{CH}_{3} \mathrm{CH}_{2} \mathrm{CH}_{2} \mathrm{CH}_{2} \mathrm{~N}\right), 19.6(\mathrm{~s}$, $\left.\mathrm{CH}_{3} \mathrm{CH}_{2}\left(\mathrm{CH}_{2}\right)_{2} \mathrm{~N}\right), 13.4 \mathrm{ppm}\left(\mathrm{s}, \mathrm{CH}_{3}\left(\mathrm{CH}_{2}\right)_{3} \mathrm{~N}\right)$. Calcd for $\mathrm{C}_{42} \mathrm{H}_{60} \mathrm{AuClF}_{5} \mathrm{~N}$ (found) C, 55.64 (55.64); H, 6.68 (6.58); N, 1.55 (1.68) \%.

In Situ NMR Experiments and Data. $(C \wedge C \wedge N) A u H$ (4). $\left(\mathrm{C}^{\wedge} \mathrm{C}^{\wedge} \mathrm{N}\right) \mathrm{AuCl}(\mathbf{1})(15 \mathrm{mg}, 0.0226 \mathrm{mmol})$ was loaded into a screw cap NMR within the glovebox and approximately $0.7 \mathrm{~mL}$ of dry THF- $d_{8}$ were added under Ar. The resultant suspension was sonicated at room temperature for $10 \mathrm{~s}$ to obtain a pale-yellow solution. The NMR tube was then inserted in a cold bath at $195 \mathrm{~K}$ and, using a microsyringe, $\mathrm{LiHBEt}_{3}$ (1 equiv, $22.6 \mu \mathrm{L}$ of a $1.0 \mathrm{M}$ solution in THF) was injected through the septum. The sample was quickly shaken to obtain a bright yellow solution and inserted into the NMR probe and analyzed at $253 \mathrm{~K} .{ }^{1} \mathrm{H}$ NMR $(300.13 \mathrm{MHz}$, THF- $d_{8}, 253 \mathrm{~K}, J$ values in $\left.\mathrm{Hz}\right) \delta 8.86(\mathrm{~s}, 1 \mathrm{H}, \mathrm{H} 1), 8.00(\mathrm{~d}, 1 \mathrm{H}$, $\left.{ }^{3} J_{\mathrm{HH}}=8.3, \mathrm{H} 4\right), 7.89\left(\mathrm{~d}, 1 \mathrm{H},{ }^{3} J_{\mathrm{HH}}=8.3, \mathrm{H} 3\right), 7.70(\mathrm{~s}, 2 \mathrm{H}$, $\mathrm{H} 7+\mathrm{H} 16), 7.65$ (d, 2H, $\left.{ }^{3} J_{\mathrm{HH}}=8.3, \mathrm{H} 19\right), 7.58(\mathrm{~s}, 1 \mathrm{H}, \mathrm{H} 9), 7.50$ (d, $\left.2 \mathrm{H},{ }^{3} J_{\mathrm{HH}}=8.3, \mathrm{H} 20\right), 7.37\left(\mathrm{~d}, 1 \mathrm{H},{ }^{3} J_{\mathrm{HH}}=8.1, \mathrm{H} 13\right), 7.17(\mathrm{dd}, 1 \mathrm{H}$, $\left.{ }^{3} J_{\mathrm{HH}}=8.1{ }^{4} J_{\mathrm{HH}}=1.8, \mathrm{H} 14\right), 6.33(\mathrm{~s}, 1 \mathrm{H}, \mathrm{Au}-\mathrm{H}), 2.36(\mathrm{~s}, 3 \mathrm{H}, \mathrm{Me})$, 1.38 (s, 9H, C(21) $\left.\mathrm{CMe}_{3}\right), 1.34 \mathrm{ppm}\left(\mathrm{s}, 9 \mathrm{H}, \mathrm{C}(15) \mathrm{CMe}_{3}\right) \cdot{ }^{13} \mathrm{C}\left\{{ }^{1} \mathrm{H}\right\}$ NMR (75.47 MHz, THF- $\left.d_{8}, 253 \mathrm{~K}\right) \delta 184.2(\mathrm{~s}, \mathrm{C} 11), 165.9$ (s, C5), 156.0 (s, C1), 154.9 (s, C12), 151.8 (s, C10), 150.8 (s, C15), 150.2 (s, C21), 145.3 (s, C17), 144.3 (s, C6), 141.5 (s, C3), 140.8 (s, C8), 139.9 (s, C18), 138.4 (s, C16), 136.3 (s, C2), 127.4 (s, C19), 126.1 (s, C20), 123.8 (s, C14), 121.9 (s, C13), 120.9 (s, C7+C9), 120.8 (s, C4), 35.1 (s, $\left.\mathrm{C}(15) \mathrm{CMe}_{3}\right), 35.0$ (s, $\left.\mathrm{C}(21) \mathrm{CMe}_{3}\right), 31.5$ (s+s, $\left.\mathrm{C}(15) \mathrm{CMe}_{3}+\mathrm{C}(21) \mathrm{CMe}_{3}\right), 17.9 \mathrm{ppm}(\mathrm{s}, \mathrm{Me}) . \mathrm{T}_{1}\left(253 \mathrm{~K}, \mathrm{THF}-d_{8}\right)$ $\mathrm{Au}-\mathrm{H} 1.30 \mathrm{~s}$.

$\mathrm{Li}\left[(\mathrm{C} \wedge \mathrm{C} \wedge \mathrm{N}) \mathrm{AuH}_{2}\right]$ (5). Procedure (a): In the glovebox under $\mathrm{N}_{2}, \mathbf{1}$ (10 $\mathrm{mg}, 0.015 \mathrm{mmol}$ ) was loaded into a screw-cap NMR tube, and approximately $0.7 \mathrm{~mL}$ of dry THF- $d_{8}$ were added. The resultant suspension was sonicated at room temperature for $10 \mathrm{~s}$ to obtain a pale-yellow solution. The NMR tube was then inserted in a cold bath at $195 \mathrm{~K}$ and 2.0 equiv $\mathrm{LiHBEt}_{3}(30.2 \mu \mathrm{L}$ of a $1.0 \mathrm{M}$ solution in THF) were injected through the septum by using a microsyringe. The sample was quickly shaken to give a colorless solution and analyzed at $263 \mathrm{~K}$. Procedure (b): In the glovebox under $\mathrm{N}_{2}, 15 \mathrm{mg}$ of 1 and 3.0 equiv of solid $\mathrm{LiAlH}_{4}(2.5 \mathrm{mg})$ were loaded into a screw cap NMR tube. The NMR tube was inserted in a cold bath at $195 \mathrm{~K}$ and approximately $0.7 \mathrm{~mL}$ of dry THF- $d_{8}$ were added. The resultant dark suspension was shaken and the NMR tube was inserted into the precooled NMR probe and analyzed at $203 \mathrm{~K} .{ }^{1} \mathrm{H}$ NMR $(300.13$ MHz, THF- $d_{8}, 263 \mathrm{~K}, J$ values in $\left.\mathrm{Hz}\right) \delta 8.26(\mathrm{~s}, 1 \mathrm{H}, \mathrm{H1}), 8.08(\mathrm{~m}$, 1H, H16), 7.72 (s, 1H, H9), 7.58 (m, 4H, H3+H4+H19), 7.43 (m, $4 \mathrm{H}, \mathrm{H} 7+\mathrm{H} 13+\mathrm{H} 20), 6.98\left(\mathrm{dd},{ }^{3} J_{\mathrm{HH}}=8.1{ }^{4} J_{\mathrm{HH}}=2.1,1 \mathrm{H}, \mathrm{H} 14\right), 2.37$ (s, 3H, Me), 1.35 (s, 9H, (C21) $\mathrm{CMe}_{3}$ ), 1.31 (s, 9H, (C15) $\mathrm{CMe}_{3}$ ), $-0.31\left(\mathrm{ps} \mathrm{t}, 1 \mathrm{H},{ }^{2} J_{\mathrm{HH}}=4.3, \mathrm{Au}-\mathrm{H}_{\mathrm{b}}\right),-0.59 \mathrm{ppm}\left(\mathrm{d}, 1 \mathrm{H},{ }^{2} J_{\mathrm{HH}}=4.3\right.$, $\left.\mathrm{Au}-\mathrm{H}_{\mathrm{a}}\right) .{ }^{13} \mathrm{C}\left\{{ }^{1} \mathrm{H}\right\}$ NMR $\left(75.47 \mathrm{MHz}\right.$, THF- $\left.d_{8}, 263 \mathrm{~K}\right) \delta 172.3(\mathrm{~s}$, C17), 171.1 (s, C11), 167.2 (s, C5), 161.1 (s, C10), 155.4 (s, C12), 149.6 (s, C21), 149.2 (s, C6), 148.8 (s, C15), 147.5 (s, C1), 140.7 (s, C18), 140.4 (s, C16), 138.1 (s, C8), 137.0 (s, C3), 130.7 (s, C2), 126.9 (s, C19), 126.8 (s, C4), 125.9 (s, C20), 124.3 (s, C7), 120.7 (s, C14), 120.4 (s, C13), 118.6 (s, C9), 34.8 (s, C(15) CMe 3 ), 34.7 
(s, C(21) $\mathrm{CMe}_{3}$ ), 32.0 (s, C(15) $\mathrm{CMe}_{3}$ ), 31.6 (s, C(21)CMe $\left.\mathrm{C}_{3}\right), 18.4$ ppm (s, Me). $\mathrm{T}_{1}\left(-20{ }^{\circ} \mathrm{C}\right.$, THF- $\left.d_{8}\right) \mathrm{Au}-\mathrm{H}_{\mathrm{a}} 0.80 \mathrm{~s}, \mathrm{Au}-\mathrm{H}_{\mathrm{b}} 0.82 \mathrm{~s}$. $L i[(C \wedge C) A u(H) C l]$ (6). In a glovebox under $\mathrm{N}_{2}, 2(15 \mathrm{mg}, 0.026$ $\mathrm{mmol}$ ) was loaded into a screw-cap NMR tube and dissolved in approximately $0.7 \mathrm{~mL}$ of dry THF- $d_{8}$. The NMR tube was then inserted in a cold bath at $195 \mathrm{~K}$ and 2.0 equiv $\mathrm{LiHBEt}_{3}(52.0 \mu \mathrm{L}$ of a 1.0 $\mathrm{M}$ solution in THF) were injected through the septum, using a microsyringe. The sample was quickly shaken to obtain a bright yellow solution and inserted into the NMR probe and analyzed at $213 \mathrm{~K} .{ }^{1} \mathrm{H}$ NMR $\left(300.13 \mathrm{MHz}\right.$, THF- $d_{8}, 213 \mathrm{~K}, J$ values in $\left.\mathrm{Hz}\right) \delta$ $8.01\left(\mathrm{~m}, 1 \mathrm{H}, \mathrm{H} 2^{\prime}\right), 7.72$ (overlapped with py signals, $1 \mathrm{H}, \mathrm{H} 2$ ), 7.20 $\left(\mathrm{d}, 1 \mathrm{H},{ }^{3} J_{\mathrm{HH}}=8.2, \mathrm{H} 5\right), 7.17\left(\mathrm{~d}, 1 \mathrm{H},{ }^{3} J_{\mathrm{HH}}=8.2, \mathrm{H} 5^{\prime}\right) .6 .96(\mathrm{br} \mathrm{d}$, $\left.1 \mathrm{H},{ }^{3} J_{\mathrm{HH}}=8.2, \mathrm{H} 4\right), 6.90\left(\mathrm{dd}, 1 \mathrm{H},{ }^{3} J_{\mathrm{HH}}=8.2{ }^{4} J_{\mathrm{HH}}=1.8, \mathrm{H} 4^{\prime}\right), 2.43$ (br s, $1 \mathrm{H}, \mathrm{Au}-\mathrm{H}$ ), 1.27 (s, 9H, $\mathrm{CMe}_{3}$ ), $1.25 \mathrm{ppm}$ (s, 9H, $\mathrm{CMe}_{3}{ }^{\prime}$ ). ${ }^{13} \mathrm{C}\left\{{ }^{1} \mathrm{H}\right\}$ NMR $\left(75.47 \mathrm{MHz}, \mathrm{THF}-d_{8}, 213 \mathrm{~K}\right) \delta 174.8\left(\mathrm{~s}, \mathrm{C1}^{\prime}\right), 153.0$ (s, C6), 151.4 (s, C6'), 149.3 (s, C3), 148.4 (s, C1), 147.1 (s, C3'), 139.1 (s, C2), 129.9 (s, C2'), 121.9 (s, C4), 121.8 (s, C4'), 120.1 (s, $\mathrm{C5}), 118.9$ (s, C5' $), 34.7\left(\mathrm{~s}, \mathrm{CMe}_{3}\right), 34.1 \mathrm{ppm}\left(\mathrm{s}, \mathrm{CMe}_{3}{ }^{\prime}\right), 31.2+$ $31.1\left(\mathrm{~s}+\mathrm{s}, \mathrm{CMe}_{3}+\mathrm{CMe}{ }_{3}{ }^{\prime}\right)$.

$(C \wedge C) A u H(D M A P)$ (7). A sample of 6 was generated as described above from $15 \mathrm{mg}$ of 2 and kept at $195 \mathrm{~K}$. Successively, 4.0 equiv of DMAP $\left(12.7 \mathrm{mg}\right.$ ) were dissolved in $0.3 \mathrm{~mL}$ of dry THF- $d_{8}$ and injected through the septum by using a gastight syringe to obtain a yellow solution. The sample was then transferred into the precooled NMR probe and analyzed at $253 \mathrm{~K} .{ }^{1} \mathrm{H}$ NMR $(300.13 \mathrm{MHz}$, THF$d_{8}, 253 \mathrm{~K}, J$ values in $\left.\mathrm{Hz}\right) \delta 8.32\left(\mathrm{~d},{ }^{3} J_{\mathrm{HH}}=7.1,2 \mathrm{H}, \mathrm{H} 7\right), 7.74(\mathrm{ps} \mathrm{t}$, $\left.{ }^{4} J_{\mathrm{HH}}=2.0,1 \mathrm{H}, \mathrm{H} 2\right), 7.27$ (m, overlapped with py signals, $\left.\mathrm{H} 5+\mathrm{H}^{\prime}\right)$, $7.03\left(\mathrm{dd},{ }^{3} \mathrm{~J}_{\mathrm{HH}}=8.1{ }^{4} \mathrm{~J}_{\mathrm{HH}}=2.0,1 \mathrm{H}, \mathrm{H} 4\right), 6.99\left(\mathrm{dd},{ }^{3} J_{\mathrm{HH}}=8.1{ }^{4} J_{\mathrm{HH}}\right.$ $\left.=2.0,1 \mathrm{H}, \mathrm{H} 4^{\prime}\right), 6.92\left(\mathrm{dd},{ }^{4} J_{\mathrm{HH}}=4.5{ }^{4} J_{\mathrm{HH}}=2.0,1 \mathrm{H}, \mathrm{H} 2^{\prime}\right), 6.89(\mathrm{~d}$, ${ }^{3} J_{\mathrm{HH}}=7.1,2 \mathrm{H}, \mathrm{H} 8$ ), 3.25 (brs, $1 \mathrm{H}, \mathrm{Au}-\mathrm{H}$ ), 3.13 (s, 6H, $\mathrm{NMe}_{2}$ ), 1.29 (s, 9H, $\left.\mathrm{CMe}_{3}\right), 1.17 \mathrm{ppm}\left(\mathrm{s}, 9 \mathrm{H}, \mathrm{CMe}_{3}{ }^{\prime}\right) \cdot{ }^{13} \mathrm{C}\left\{{ }^{1} \mathrm{H}\right\} \quad \mathrm{NMR}$ $\left(75.47 \mathrm{MHz}, \mathrm{THF}-d_{8}, 253 \mathrm{~K}\right) \delta 174.6\left(\mathrm{~s}, \mathrm{Cl}^{\prime}\right), 155.3$ (s, C9), 153.3 (s, C6), 151.8 (s, C6'), 151.1 (s, C7), 148.8 (s, C3), 148.1 (s, C3'), 144.1 (s, C1), 139.9 (s, C2), $129.0\left(\mathrm{~s}, \mathrm{C} 2^{\prime}\right), 122.8\left(\mathrm{~s}+\mathrm{s}, \mathrm{C} 4+\mathrm{C} 4^{\prime}\right)$, $119.9\left(\mathrm{~s}, \mathrm{C} 5\right.$ or $\left.\mathrm{C5}^{\prime}\right), 119.2\left(\mathrm{~s}, \mathrm{C5}^{\prime}\right.$ or C5), $108.5(\mathrm{~s}, \mathrm{C} 8), 39.0(\mathrm{~s}$, $\left.\mathrm{NMe}_{2}\right), 35.1$ (s, $\left.\mathrm{CMe}_{3}{ }^{\prime}\right), 34.7$ (s, $\left.\mathrm{CMe}_{3}\right), 31.8 \mathrm{ppm}$ (s, $\left.\mathrm{CMe}_{3}+\mathrm{CMe}_{3}{ }^{\prime}\right)$.

$(\mathrm{C} \wedge \mathrm{C}) \mathrm{AuH}\left(\mathrm{PMe}_{3}\right)$ (9). Procedure (a): A sample of 6 was generated as described above from $15 \mathrm{mg}$ of $\mathbf{2}$ and kept at $195 \mathrm{~K}$. Successively, 1.0 equiv of $\mathrm{PMe}_{3}(26 \mu \mathrm{L}$ of a $1.0 \mathrm{M}$ solution in THF) was injected through the septum by using a gastight syringe to obtain a paleyellow solution. The sample was then transferred into the precooled NMR probe and analyzed at $253 \mathrm{~K}$. Procedure (b): In the glovebox, $20 \mathrm{mg}$ of $\left(\mathrm{C}^{\wedge} \mathrm{C}\right) \mathrm{AuCl}\left(\mathrm{PMe}_{3}\right)$ were loaded into a screw-cap NMR tube and dissolved in approximately $0.7 \mathrm{~mL}$ of toluene- $d_{8}$. Outside the glovebox, 1.0 equiv $\mathrm{LiHBEt}_{3}(35 \mu \mathrm{L}$ of a $1.0 \mathrm{M}$ solution in THF) were injected through the septum by a microsyringe at room temperature to give a pale-yellow solution and a white precipitate. The solution was filtered over Celite into a J Young NMR tube and dried under vacuum to afford a pale-yellow powder, which was redissolved in dry toluene- $d_{8}$ and analyzed at room temperature. ${ }^{1} \mathrm{H}$ NMR $\left(300.13 \mathrm{MHz}\right.$, THF- $d_{8}, 253 \mathrm{~K}, J$ values in $\left.\mathrm{Hz}\right) \delta 7.94\left(\mathrm{dt},{ }^{4} J_{\mathrm{HP}}\right.$ $\left.=10.0{ }^{4} J_{\mathrm{HH}}=1.7,1 \mathrm{H}, \mathrm{H} 2\right), 7.58\left(\mathrm{~m}, 1 \mathrm{H}, \mathrm{H} 2^{\prime}\right), 7.32\left(\mathrm{~d},{ }^{3} \mathrm{~J}_{\mathrm{HH}}=8.2\right.$, $\left.1 \mathrm{H}, \mathrm{H}^{\prime}\right), 7.28\left(\mathrm{dd},{ }^{3} J_{\mathrm{HH}}=8.2{ }^{5} J_{\mathrm{HP}}=4.1,1 \mathrm{H}, \mathrm{H} 5\right), 7.06(\mathrm{dd}$, partially overlapped with $\left.\mathrm{H} 4,1 \mathrm{H}, \mathrm{H} 4^{\prime}\right), 7.04$ (dd, partially overlapped with $\left.\mathrm{H}^{\prime}, 1 \mathrm{H}, \mathrm{H} 4\right), 1.89$ (d, ${ }^{2} J_{\mathrm{HP}}=10.8,9 \mathrm{H}, \mathrm{PMe}_{3}$ ), $1.53\left(\mathrm{brd},{ }^{2} J_{\mathrm{HP}}=32.6,1 \mathrm{H}, \mathrm{Au}-\mathrm{H}\right), 1.31\left(\mathrm{~s}, 9 \mathrm{H}, \mathrm{CMe}_{3}{ }^{\prime}\right), 1.28 \mathrm{ppm}$ $\left(\mathrm{s}, 9 \mathrm{H}, \mathrm{CMe}_{3}\right) \cdot{ }^{13} \mathrm{C}\left\{{ }^{1} \mathrm{H}\right\}$ NMR $\left(75.47 \mathrm{MHz}\right.$, THF- $d_{8}, 253 \mathrm{~K}, J$ values in $\mathrm{Hz}) \delta 168.4\left(\mathrm{~d},{ }^{2} J_{\mathrm{PC}}=4.6, \mathrm{Cl}^{\prime}\right), 160.6\left(\mathrm{~d},{ }^{2} J_{\mathrm{PC}}=136.2, \mathrm{C} 1\right)$, $154.8\left(\mathrm{~d},{ }^{3} J_{\mathrm{PC}}=5.5, \mathrm{C} 6\right), 154.1\left(\mathrm{~s}, \mathrm{C} 6{ }^{\prime}\right), 149.3\left(\mathrm{~d},{ }^{4} J_{\mathrm{PC}}=10.0, \mathrm{C} 3\right)$, $148.4\left(\mathrm{~s}, \mathrm{C} 3^{\prime}\right), 140.8\left(\mathrm{~d},{ }^{3} J_{\mathrm{PC}}=5.4, \mathrm{C} 2\right), 133.0\left(\mathrm{~d},{ }^{3} J_{\mathrm{PC}}=6.6, \mathrm{C}^{\prime}\right)$, $123.0\left(\mathrm{~s}+\mathrm{s}, \mathrm{C} 4+\mathrm{C} 4^{\prime}\right), 120.5\left(\mathrm{~m}, \mathrm{H} 5+\mathrm{H}^{\prime}\right), 35.0\left(\mathrm{~s}, \mathrm{CMe}_{3}{ }^{\prime}\right), 34.8(\mathrm{~s}$, $\left.\mathrm{CMe}_{3}\right), 31.7\left(\mathrm{~s}+\mathrm{s}, \mathrm{CMe}_{3}+\mathrm{CMe}_{3}{ }^{\prime}\right), 15.9 \mathrm{ppm}\left(\mathrm{d},{ }^{1} J_{\mathrm{CP}}=32.5, \mathrm{PMe}_{3}\right)$. ${ }^{31} \mathrm{P}\left\{{ }^{1} \mathrm{H}\right\}$ NMR $\left(121.49 \mathrm{MHz}\right.$, THF- $\left.d_{8}, 253 \mathrm{~K}\right)-8.2 \mathrm{ppm}\left(\mathrm{s}, \mathrm{PMe}_{3}\right)$. ${ }^{1} \mathrm{H}$ NMR (300.13 MHz, Toluene- $d_{8}, 298 \mathrm{~K}, J$ values in $\left.\mathrm{Hz}\right) \delta 8.49$ $\left(\mathrm{dt},{ }^{4} J_{\mathrm{HP}}=10.6{ }^{4} J_{\mathrm{HH}}=2.0,1 \mathrm{H}, \mathrm{H} 2\right), 7.58\left(\mathrm{~d},{ }^{3} J_{\mathrm{HH}}=8.2,1 \mathrm{H}, \mathrm{H} 5^{\prime}\right)$, $7.54\left(\mathrm{~m}, 2 \mathrm{H}, \mathrm{H} 2^{\prime}+\mathrm{H} 5\right), 7.22\left(\mathrm{~m}, 2 \mathrm{H}, \mathrm{H} 4+\mathrm{H} 4^{\prime}\right), 1.86\left(\mathrm{dm},{ }^{2} J_{\mathrm{HP}}=\right.$ 34.7, $1 \mathrm{H}, \mathrm{Au}-\mathrm{H}), 1.39\left(\mathrm{~s}+\mathrm{s}, 18 \mathrm{H}, \mathrm{CMe}_{3}+\mathrm{CMe}_{3}{ }^{\prime}\right), 1.03 \mathrm{ppm}\left(\mathrm{d},{ }^{2} J_{\mathrm{HP}}\right.$ $\left.=10.2,9 \mathrm{H}, \mathrm{PMe}_{3}\right)$.
$(\mathrm{C} \wedge \mathrm{C}) \mathrm{AuH}\left(\mathrm{Ptol}_{3}\right)$ (10). This complex was prepared by following the procedures described for 9 . Procedure (a) was followed by using $15 \mathrm{mg}$ of 2 and $7.9 \mathrm{mg}$ of $\mathrm{P}(p-\mathrm{tol})_{3}$ (dissolved in $0.2 \mathrm{~mL}$ of THF$d_{8}$ ). Procedure (b) was followed by using $15 \mathrm{mg}$ of $\left(\mathrm{C}^{\wedge} \mathrm{C}\right) \mathrm{AuCl}-$ $\left(\mathrm{Ptol}_{3}\right)$ and $19 \mu \mathrm{L}$ of a $1 \mathrm{M} \mathrm{LiHBEt}_{3}$ solution in THF. ${ }^{1} \mathrm{H}$ NMR $\left(300.13 \mathrm{MHz}\right.$, THF- $d_{8}, 213 \mathrm{~K}, J$ values in $\left.\mathrm{Hz}\right) \delta 8.00\left(\mathrm{br} \mathrm{d},{ }^{4} J_{\mathrm{HP}}=\right.$ 9.3, H2), 7.49 (m, 6H, H8), 7.34 (m, 8H, H5+H5'+H9), 7.08 (dd, $\left.{ }^{3} J_{\mathrm{HH}}=8.1{ }^{4} \mathrm{~J}_{\mathrm{HH}}=8.1,1 \mathrm{H}, \mathrm{H} 4\right), 6.97\left(\mathrm{~m}, 1 \mathrm{H}, \mathrm{H} 2^{\prime}\right), 6.90\left(\mathrm{dd},{ }^{3} \mathrm{~J}_{\mathrm{HH}}=\right.$ $\left.8.1{ }^{4} \mathrm{~J}_{\mathrm{HH}}=8.1,1 \mathrm{H}, \mathrm{H} 4^{\prime}\right), 2.38$ (s, 9H, Me), 2.33 (brd, ${ }^{2} \mathrm{~J}_{\mathrm{PH}}=33.0$, $\mathrm{Au}-\mathrm{H}$ ), 1.28 (s, 9H, CMe ${ }_{3}$ ), 0.77 (s, 9H, $\left.\mathrm{CMe}_{3}{ }^{\prime}\right) .{ }^{13} \mathrm{C}\left\{{ }^{1} \mathrm{H}\right\}$ NMR $\left(75.47 \mathrm{MHz}\right.$, THF- $d_{8}, 213 \mathrm{~K}, J$ values in $\left.\mathrm{Hz}\right) \delta 168.4\left(\mathrm{~d},{ }^{2} J_{\mathrm{PC}}=4.7\right.$, $\left.\mathrm{C}^{\prime}\right), 159.8\left(\mathrm{~d},{ }^{2} J_{\mathrm{PC}}=129.0, \mathrm{C} 1\right), 153.7\left(\mathrm{~d},{ }^{3} J_{\mathrm{PC}}=5.0, \mathrm{C} 6\right), 153.3(\mathrm{~s}$, $\left.\mathrm{C}^{\prime}\right), 148.8\left(\mathrm{~d},{ }^{4} J_{\mathrm{PC}}=9.0, \mathrm{C} 3\right), 147.7\left(\mathrm{~s}, \mathrm{C}^{\prime}\right), 142.1$ (s, C10). 140.3 $\left(\mathrm{d},{ }^{3} J_{\mathrm{PC}}=4.0, \mathrm{C} 2\right), 136.2\left(\mathrm{br} \mathrm{d},{ }^{3} J_{\mathrm{PC}}=4.3, \mathrm{C} 2{ }^{\prime}\right), 134.6\left(\mathrm{~d},{ }^{3} J_{\mathrm{PC}}=\right.$ $12.5, \mathrm{C} 8), 129.8\left(\mathrm{~d},{ }^{4} J_{\mathrm{PC}}=11.0, \mathrm{C} 9\right), 126.8\left(\mathrm{~d},{ }^{1} J_{\mathrm{PC}}=56.0, \mathrm{C} 7\right)$, $122.5(\mathrm{~s}, \mathrm{C} 4), 121.5\left(\mathrm{~s}, \mathrm{C} 4{ }^{\prime}\right), 120.0\left(\mathrm{~d},{ }^{4} J_{\mathrm{PC}}=6.5, \mathrm{C} 5\right), 119.4(\mathrm{~s}$, $\left.\mathrm{C5}^{\prime}\right), 34.3\left(\mathrm{~s}, \mathrm{CMe}_{3}\right), 34.1$ (s, $\left.\mathrm{CMe}_{3}{ }^{\prime}\right), 31.0\left(\mathrm{~s}, \mathrm{CMe}_{3}\right), 30.4(\mathrm{~s}$, $\left.\mathrm{CMe}_{3}{ }^{\prime}\right), 20.6 \mathrm{ppm}(\mathrm{s}, \mathrm{Me}) .{ }^{31} \mathrm{P}\left\{{ }^{1} \mathrm{H}\right\}$ NMR $\left(121.49 \mathrm{MHz}, \mathrm{THF}-d_{8}\right.$, $213 \mathrm{~K}) 32.6 \mathrm{ppm}\left(\mathrm{s}, \mathrm{Ptol}_{3}\right) .{ }^{1} \mathrm{H}$ NMR $\left(300.13 \mathrm{MHz}\right.$, Toluene- $d_{8}, 298$ $\mathrm{K}, J$ values in $\mathrm{Hz}) \delta 8.60\left(\mathrm{br} \mathrm{d},{ }^{4} J_{\mathrm{HP}}=9.7,1 \mathrm{H}, \mathrm{H} 2\right), 7.58(\mathrm{~m}, 2 \mathrm{H}$, $\left.\mathrm{H} 5+\mathrm{H}^{\prime}\right), 7.51\left(\mathrm{dd},{ }^{3} J_{\mathrm{HP}}=12.3{ }^{3} \mathrm{~J}_{\mathrm{HH}}=8.2,6 \mathrm{H}, \mathrm{H} 8\right), 7.25(\mathrm{~m}, 2 \mathrm{H}$, $\left.\mathrm{H} 2^{\prime}+\mathrm{H} 4\right), 7.15\left(\mathrm{dd},{ }^{3} J_{\mathrm{HH}}=8.2{ }^{4} J_{\mathrm{HH}}=1.5,1 \mathrm{H}, \mathrm{H} 4^{\prime}\right), 6.79\left(\mathrm{~d},{ }^{3} J_{\mathrm{HH}}=\right.$ 8.2, 6H, H9), $2.94\left(\mathrm{br} \mathrm{d},{ }^{2} J_{\mathrm{HP}}=32.4,1 \mathrm{H}, \mathrm{Au}-\mathrm{H}\right), 1.98$ (s, 9H, Me), 1.38 (s, 9H, $\left.\mathrm{CMe}_{3}\right), 1.02 \mathrm{ppm}\left(\mathrm{s}, 9 \mathrm{H}, \mathrm{CMe}_{3}{ }^{\prime}\right)$.

$(C \wedge C) A u H\left(P P h_{3}\right)$ (11). This complex was synthesized by following the procedure reported for $\left(\mathrm{C}^{\wedge} \mathrm{C}\right) \mathrm{AuH}\left(\mathrm{PMe}_{3}\right)$, by using $15 \mathrm{mg}$ of $\mathbf{2}$, $26 \mu \mathrm{L}$ of $\mathrm{LiHBEt}_{3}$ and 1.0 equiv of $\mathrm{PPh}_{3}(6.8 \mathrm{mg})$ in dry THF- $d_{8}$. NMR characterization was carried out at $298 \mathrm{~K} .{ }^{1} \mathrm{H}$ NMR $(300.13$ $\mathrm{MHz}$, THF- $d_{8}, 298 \mathrm{~K}, J$ values in $\left.\mathrm{Hz}\right) \delta 8.02\left(\mathrm{brd},{ }^{4} J_{\mathrm{HP}}=9.7,1 \mathrm{H}\right.$, $\mathrm{H} 2), 7.66(\mathrm{~m}$, overlapped with py signals, $\mathrm{H} 8), 7.50(\mathrm{~m}, 9 \mathrm{H}$, $\mathrm{H} 9+\mathrm{H} 10), 7.30\left(\mathrm{~m}, 2 \mathrm{H}, \mathrm{H} 5+\mathrm{H}^{\prime}\right), 7.09\left(\mathrm{brd},{ }^{3} J_{\mathrm{HH}}=8.3,1 \mathrm{H}, \mathrm{H} 4\right)$, 7.05 (brs, $1 \mathrm{H}, \mathrm{H}^{\prime}$ ), 6.92 (brd, $\left.{ }^{3} J_{\mathrm{HH}}=8.3,1 \mathrm{H}, \mathrm{H} 4^{\prime}\right), 2.40$ (brd, ${ }^{2} J_{\mathrm{HP}}$ $=32.3,1 \mathrm{H}, \mathrm{Au}-\mathrm{H}), 1.29\left(\mathrm{~s}, 9 \mathrm{H}, \mathrm{CMe}_{3}\right), 0.81 \mathrm{ppm}\left(\mathrm{s}, 9 \mathrm{H}, \mathrm{CMe}_{3}{ }^{\prime}\right)$. ${ }^{13} \mathrm{C}\left\{{ }^{1} \mathrm{H}\right\}$ NMR $\left(75.47 \mathrm{MHz}\right.$, THF- $d_{8}, 298 \mathrm{~K}, J$ values in $\left.\mathrm{Hz}\right) \delta 169.3$ $\left(\mathrm{d},{ }^{2} J_{\mathrm{PC}}=5.1, \mathrm{Cl}^{\prime}\right), 160.5\left(\mathrm{~d},{ }^{2} J_{\mathrm{PC}}=129.5, \mathrm{C} 1\right), 154.5\left(\mathrm{~d},{ }^{3} J_{\mathrm{PC}}=5.2\right.$, C6), 154.1 (s, C6 $\left.{ }^{\prime}\right), 149.8$ (d, $\left.{ }^{4} J_{\mathrm{PC}}=9.4, \mathrm{C} 3\right), 148.8\left(\mathrm{~s}, \mathrm{C}^{\prime}\right), 140.9$ $\left(\mathrm{d},{ }^{3} \mathrm{~J}_{\mathrm{PC}}=4.7, \mathrm{C} 2\right), 136.5\left(\mathrm{~d},{ }^{3} \mathrm{~J}_{\mathrm{PC}}=5.5, \mathrm{C} 2\right.$ ) $), 135.4\left(\mathrm{~d},{ }^{3} \mathrm{~J}_{\mathrm{PC}}=12.6\right.$, C8), 132.2 (br s, C10), 131.0 (d, $\left.{ }^{1} J_{\mathrm{CP}}=49.9, \mathrm{C} 7\right), 129.7$ (d, ${ }^{4} J_{\mathrm{PC}}=$ 10.9. C9), 123.3 (s, C4), 122.5 (s, C4'), 120.8 (d, $\left.{ }^{4} J_{\mathrm{PC}}=7.2, \mathrm{C} 5\right)$, 120.2 (s, C5'), 34.9 (s, $\mathrm{CMe}_{3}$ ), $34.6\left(\mathrm{~s}, \mathrm{CMe}_{3}{ }^{\prime}\right), 31.7\left(\mathrm{~s}, \mathrm{CMe}_{3}\right), 31.4$ ppm $\left(\mathrm{s}, \mathrm{CMe}_{3}{ }^{\prime}\right) .{ }^{31} \mathrm{P}\left\{{ }^{1} \mathrm{H}\right\}$ NMR (121.49 MHz, THF- $\left.d_{8}, 298 \mathrm{~K}\right) 34.9$ ppm $\left(\mathrm{s}, \mathrm{PPh}_{3}\right)$.

$(\mathrm{C} \wedge \mathrm{C}) \mathrm{Au}\left(\mathrm{Z}-\mathrm{C}_{2} \mathrm{H}\left(\mathrm{CO}_{2} \mathrm{Me}_{2}\right)\left(\mathrm{PMe}_{3}\right)\right.$ (12). A sample of 9 was generated from $15 \mathrm{mg}$ of 2 in THF- $d_{8}$ and treated with 2 equiv DMAD at room temperature. The conversion to the vinyl complex was complete in $2 \mathrm{~h}$. NMR characterization was performed in mixture with py-BEt ${ }_{3}$, at $298 \mathrm{~K} .{ }^{1} \mathrm{H}$ NMR $\left(300.13 \mathrm{MHz}\right.$, THF- $d_{8}, 298 \mathrm{~K}, J$ values in $\mathrm{Hz}) \delta 7.54\left(\mathrm{~m}, 3 \mathrm{H}, \mathrm{H} 2+\mathrm{H} 2^{\prime}+\mathrm{H} 8\right), 7.32\left(\mathrm{~d},{ }^{3} J_{\mathrm{HH}}=8.2,1 \mathrm{H}\right.$, $\left.\mathrm{H}^{\prime}\right), 7.23\left(\mathrm{dd},{ }^{3} \mathrm{~J}_{\mathrm{HH}}=8.2{ }^{5} \mathrm{~J}_{\mathrm{HP}}=3.8,1 \mathrm{H}, \mathrm{H} 5\right), 7.11\left(\mathrm{dd},{ }^{3} \mathrm{~J}_{\mathrm{HH}}=8.2\right.$ $\left.{ }^{4} J_{\mathrm{HH}}=1.9,1 \mathrm{H}, \mathrm{H}^{\prime}\right), 7.01\left(\mathrm{dd},{ }^{3} J_{\mathrm{HH}}=8.2{ }^{4} J_{\mathrm{HH}}=1.7,1 \mathrm{H}, \mathrm{H} 4\right), 3.68$ (s, 3H, H10), 3.59 (buried under THF, H12), 1.78 (buried under THF, $\mathrm{PMe}_{3}$ ), 1.34 (s, 9H, $\left.\mathrm{CMe}_{3}{ }^{\prime}\right), 1.24 \mathrm{ppm}$ (s, 9H, $\mathrm{CMe}_{3}$ ). ${ }^{13} \mathrm{C}\left\{{ }^{1} \mathrm{H}\right\}$ NMR $\left(75.47 \mathrm{MHz}, \mathrm{THF}-d_{8}, 298 \mathrm{~K}, J\right.$ values in $\left.\mathrm{Hz}\right) \delta 184.1$ $\left(\mathrm{d},{ }^{2} J_{\mathrm{CP}}=14.8, \mathrm{C} 7\right), 173.4(\mathrm{~s}, \mathrm{C} 9), 170.0(\mathrm{~s}, \mathrm{C} 11), 159.5\left(\mathrm{~d},{ }^{2} J_{\mathrm{CP}}=\right.$ 138.0, C1), $158.7\left(\mathrm{~s}, \mathrm{C} 1^{\prime}\right), 153.3\left(\mathrm{~d},{ }^{3} J_{\mathrm{CP}}=5.1, \mathrm{C} 6\right), 152.2\left(\mathrm{~s}, \mathrm{C}^{\prime}\right)$, $148.1\left(\mathrm{~d},{ }^{4} J_{\mathrm{CP}}=9.4, \mathrm{C} 3\right), 147.8\left(\mathrm{~s}, \mathrm{C} 3^{\prime}\right), 131.7\left(\mathrm{~d},{ }^{3} J_{\mathrm{CP}}=3.5, \mathrm{C} 2^{\prime}\right)$, $131.6\left(\mathrm{~d},{ }^{3} J_{\mathrm{CP}}=9.0, \mathrm{C} 2\right), 127.1\left(\mathrm{~d},{ }^{3} J_{\mathrm{CP}}=3.0, \mathrm{C} 8\right), 122.6(\mathrm{~s}$, C4+C4'), $120.2\left(\mathrm{~s}, \mathrm{C}^{\prime}\right), 119.9\left(\mathrm{~d},{ }^{4} \mathrm{~J}_{\mathrm{CP}}=7.4, \mathrm{C} 5\right), 51.0(\mathrm{~s}, \mathrm{C} 10)$, 50.6 (s, C12), 34.5 (s, $\left.\mathrm{CMe}_{3}\right), 34.3\left(\mathrm{~s}, \mathrm{CMe}_{3}{ }^{\prime}\right), 31.1\left(\mathrm{~s}, \mathrm{CMe}_{3}{ }^{\prime}\right), 30.8$ $\left(\mathrm{s}, \mathrm{CMe} e_{3}\right), 13.1 \mathrm{ppm}\left(\mathrm{d},{ }^{1} J_{\mathrm{CP}}=31.7, \mathrm{PMe}_{3}\right) .{ }^{31} \mathrm{P}\left\{{ }^{1} \mathrm{H}\right\}$ NMR $(121.49$ $\left.\mathrm{MHz}, \mathrm{THF}-d_{8}, 298 \mathrm{~K}\right)-5.6 \mathrm{ppm}\left(\mathrm{s}, \mathrm{PMe}_{3}\right)$.

$(\mathrm{C} \wedge \mathrm{C}) \mathrm{Au}\left(\mathrm{Z}-\mathrm{C}_{2} \mathrm{H}\left(\mathrm{CO}_{2} \mathrm{Me}_{2}\right)\left(\mathrm{PtOl}_{3}\right)\right.$ (13). A sample of 10 was generated from $15 \mathrm{mg}$ of 2 in THF- $d_{8}$ and treated with 2 equiv DMAD at room temperature. The conversion into the vinyl complex was complete in $12 \mathrm{~h}$, affording 13 in $80 \%$ yield. NMR characterization was performed in mixture with py-BEt ${ }_{3}$, at $298 \mathrm{~K} .{ }^{1} \mathrm{H}$ NMR $\left(300.13 \mathrm{MHz}\right.$, THF- $d_{8}, 298 \mathrm{~K}, J$ values in $\left.\mathrm{Hz}\right) \delta 7.65$ (br, overlapped with pyridine signals, $\mathrm{H} 14), 7.42\left(\mathrm{dd}, 1 \mathrm{H},{ }^{4} J_{\mathrm{HP}}=9.5,{ }^{4} J_{\mathrm{HH}}=1.6\right.$, $\mathrm{H} 2^{\prime}$ ), 7.2 (m, 6H, H15), 7.06 (m, 2H, H4'+H8), 6.95 (br t, $1 \mathrm{H}$, 
$\mathrm{H} 2), 6.88\left(\mathrm{dd},{ }^{3} J_{\mathrm{HH}}=8.0,{ }^{4} J_{\mathrm{HH}}=1.7, \mathrm{H} 2^{\prime}\right), 3.46(\mathrm{~s}, 3 \mathrm{H}, \mathrm{H} 10), 3.43$ (s, 3H, H12), 2.35 (s, 9H, PhMe), 1.20 (s, 9H, $\mathrm{CMe}_{3}$ ), 0.65 ppm (s, 9H, $\left.\mathrm{CMe}_{3}{ }^{\prime}\right)$. Partial ${ }^{13} \mathrm{C}\left\{{ }^{1} \mathrm{H}\right\}$ NMR $\left(75.47 \mathrm{MHz}\right.$, THF- $d_{8}, 298 \mathrm{~K}, J$ values in $\mathrm{Hz}) \delta 186.0\left(\mathrm{~d},{ }^{2} J_{\mathrm{CP}}=13.3, \mathrm{C} 7\right), 172.1(\mathrm{~s}, \mathrm{C} 9), 169.2(\mathrm{~s}$, $\mathrm{C} 11), 159.6\left(\mathrm{~d},{ }^{2} J_{\mathrm{CP}}=126.3, \mathrm{C} 1\right), 159.3\left(\mathrm{~d},{ }^{2} J_{\mathrm{CP}}=6.3, \mathrm{Cl}^{\prime}\right), 152.8$ $\left(\mathrm{d},{ }^{4} J_{\mathrm{CP}}=4.0, \mathrm{C}^{\prime}\right), 152.6(\mathrm{~s}, \mathrm{C} 6), 148.2\left(\mathrm{~d},{ }^{4} J_{\mathrm{CP}}=8.7, \mathrm{C} 3\right), 147.2$ (s, C3'), 141.5 (s, C16), $137.0\left(\mathrm{~d},{ }^{3} J_{\mathrm{CP}}=8.8, \mathrm{C} 2{ }^{\prime}\right), 135.3$ (br, C14), $131.7\left(\mathrm{~d},{ }^{3} J_{\mathrm{CP}}=2.4, \mathrm{C} 2\right), 129.1(\mathrm{brs}, \mathrm{C} 8), 128.7\left(\mathrm{~d},{ }^{3} J_{\mathrm{CP}}=12.4\right.$, C15), $126.8\left(\mathrm{~d},{ }^{1} \mathrm{~J}_{\mathrm{PC}}=49.8, \mathrm{C} 7\right), 122.7(\mathrm{~s}, \mathrm{C} 4), 121.5\left(\mathrm{~s}, \mathrm{C}^{\prime}\right), 119.9$ $\left.\left(\mathrm{d},{ }^{4} J_{\mathrm{CP}}=6.9, \mathrm{C} 5\right), 119.2(\mathrm{~s}, \mathrm{C5})^{\prime}\right), 50.5$ (s, C10), 50.2 (s, C12), 34.5 (s, $\left.\mathrm{CMe}_{3}\right), 33.8$ (s, $\left.\mathrm{CMe}_{3}{ }^{\prime}\right), 30.8\left(\mathrm{~s}, \mathrm{CMe}_{3}\right), 30.3\left(\mathrm{~s}, \mathrm{CMe}_{3}{ }^{\prime}\right), 20.4$ ppm (s, (C16)Me). ${ }^{31} \mathrm{P}\left\{{ }^{1} \mathrm{H}\right\}$ NMR (121.49 MHz, THF- $\left.d_{8}, 298 \mathrm{~K}\right)$ $33.2 \mathrm{ppm}\left(\mathrm{s}, \mathrm{Ptol}_{3}\right)$.

$\mathrm{Li}\left[(\mathrm{C} \wedge \mathrm{C}) \mathrm{AuH}_{2}\right]$ (14). A solution of 10 in THF- $d_{8}$ was generated from $15 \mathrm{mg}$ of 2 as described above. Successively, a second equivalent of $\mathrm{LiHBEt}_{3}$ was added to the solution at room temperature and the slow conversion of the monohydride to the dihydride anion was observed, with liberation of free $\mathrm{Ptol}_{3} .{ }^{1} \mathrm{H}$ NMR $\left(300.13 \mathrm{MHz}, \mathrm{THF}-d_{8}, 298 \mathrm{~K}, J\right.$ values in $\left.\mathrm{Hz}\right) \delta 8.00(\mathrm{~m}, 2 \mathrm{H}, \mathrm{H} 2)$, $7.17\left(\mathrm{~d},{ }^{3} \mathrm{~J}_{\mathrm{HH}}=8.1,2 \mathrm{H}, \mathrm{H} 5\right), 6.86\left(\mathrm{dd},{ }^{3} J_{\mathrm{HH}}=8.1{ }^{4} J_{\mathrm{HH}}=2.2,2 \mathrm{H}\right.$, $\mathrm{H} 4), 1.27\left(\mathrm{~s}, 18 \mathrm{H}, \mathrm{CMe}_{3}\right), 0.09 \mathrm{ppm}\left(\mathrm{ps} \mathrm{t},{ }^{4} \mathrm{~J}_{\mathrm{HH}}=2.3,2 \mathrm{H}, \mathrm{Au}-\mathrm{H}\right)$. ${ }^{13} \mathrm{C}\left\{{ }^{1} \mathrm{H}\right\}$ NMR $\left(75.47 \mathrm{MHz}\right.$, THF- $\left.d_{8}, 298 \mathrm{~K}\right) \delta 170.7$ (s, C1), 156.2 (s, C6), 147.7 (s, C3), 140.2 (s, C2), 120.3 (s, C4), 119.2 (s, C5), $34.6\left(\mathrm{~s}, \mathrm{CMe}_{3}\right), 32.0 \mathrm{ppm}\left(\mathrm{s}, \mathrm{CMe}_{3}\right) .{ }^{1} \mathrm{H}$ NMR (300.13 MHz, Toluene- $d_{8}, 298 \mathrm{~K}, J$ values in $\left.\mathrm{Hz}\right) \delta 8.36(\mathrm{~m}, 2 \mathrm{H}, \mathrm{H} 2), 7.55\left(\mathrm{~d},{ }^{3} \mathrm{~J}_{\mathrm{HH}}\right.$ $=8.1,2 \mathrm{H}, \mathrm{H} 5), 7.20\left(\mathrm{dd},{ }^{3} \mathrm{~J}_{\mathrm{HH}}=8.1{ }^{4} \mathrm{~J}_{\mathrm{HH}}=2.0,2 \mathrm{H}, \mathrm{H} 4\right), 1.41(\mathrm{~s}$, $18 \mathrm{H}, \mathrm{CMe}_{3}$ ), $1.00 \mathrm{ppm}$ (ps t, ${ }^{4} J_{\mathrm{HH}}=2.3,2 \mathrm{H}, \mathrm{Au}-\mathrm{H}$ ).

$\left[N B u_{4}\right]\left[(C \wedge C) A u(H) C_{6} F_{5}\right]$ (16). Procedure (a): In the glovebox, 15 $\mathrm{mg}$ of $\left[\mathrm{NBu}_{4}\right]\left[\left(\mathrm{C}^{\wedge} \mathrm{C}\right) \mathrm{Au}(\mathrm{Cl}) \mathrm{C}_{6} \mathrm{~F}_{5}\right]$ (15) were loaded into a screw cap NMR tube and dissolved in approximately $0.7 \mathrm{~mL}$ of THF- $d_{8}$. Successively, 1.2 equiv of $\mathrm{LiHBEt}_{3}$ were added at $195 \mathrm{~K}$ and the sample was then allowed to warm up at room temperature. The reaction went to completion in $24 \mathrm{~h}$ at room temperature. Procedure (b): In the glovebox, $20 \mathrm{mg}$ of 15 were loaded into a screw-cap NMR tube and suspended in approximately $0.7 \mathrm{~mL}$ of toluene- $d_{8}$. Successively, 1.2 equiv $\mathrm{LiHBEt}_{3}$ were added at room temperature to afford a pale-yellow solution with an off-white precipitate. The solution was filtered into a J-young NMR tube, dried under vacuum and redissolved in THF- $d_{8} .{ }^{1} \mathrm{H}$ NMR $\left(300.13 \mathrm{MHz}\right.$, THF- $d_{8}, 298 \mathrm{~K}$, $J$ values in $\mathrm{Hz}) \delta 8.07(\mathrm{~m}, 1 \mathrm{H}, \mathrm{H} 2), 7.26\left(\mathrm{~d},{ }^{3} J_{\mathrm{HH}}=8.1,1 \mathrm{H}, \mathrm{H} 5\right)$, $7.23\left(\mathrm{~d},{ }^{3} \mathrm{~J}_{\mathrm{HH}}=8.1,1 \mathrm{H}, \mathrm{H} 5^{\prime}\right), 7.09\left(\mathrm{~m}, 1 \mathrm{H}, \mathrm{H} 2^{\prime}\right), 7.00\left(\mathrm{dd},{ }^{3} \mathrm{~J}_{\mathrm{HH}}=\right.$ $\left.8.1{ }^{4} J_{\mathrm{HH}}=2.2,1 \mathrm{H}, \mathrm{H} 4\right), 6.94\left(\mathrm{dd},{ }^{3} J_{\mathrm{HH}}=8.1{ }^{4} J_{\mathrm{HH}}=2.2,1 \mathrm{H}, \mathrm{H} 4^{\prime}\right)$, $2.91(\mathrm{~m}, 8 \mathrm{H}, \mathrm{H} \alpha), 1.35$ (br m, 8H, H $\beta), 1.32\left(\mathrm{~s}, 9 \mathrm{H}, \mathrm{CMe}_{3}\right), 1.23$ $\left(\mathrm{q},{ }^{3} \mathrm{~J}_{\mathrm{HH}}=7.8, \mathrm{H} \gamma\right), 1.15$ (overlapped with $\left.\mathrm{CMe}_{3}{ }^{\prime}, \mathrm{Au}-\mathrm{H}\right), 1.14(\mathrm{~s}$, $\left.9 \mathrm{H}, \mathrm{CMe}_{3}{ }^{\prime}\right), 0.90 \mathrm{ppm}\left(\mathrm{t}, 12 \mathrm{H},{ }^{3} \mathrm{~J}_{\mathrm{HH}}=7.8, \mathrm{H} \delta\right) .{ }^{13} \mathrm{C}\left\{{ }^{1} \mathrm{H}\right\} \mathrm{NMR}$ $\left(75.47 \mathrm{MHz}\right.$, THF- $\left.d_{8}, 298 \mathrm{~K}\right) \delta 170.3\left(\mathrm{~s}, \mathrm{Cl}^{\prime}\right), 160.1$ (brs, C1), 155.3 (s, C6 $\left.{ }^{\prime}\right), 154.3$ (s, C6), 148.8 (s, C3'), 148.0 (s, C3), 141.1 (s, $\left.\mathrm{C}^{\prime}\right), 133.1(\mathrm{~s}, \mathrm{C} 2), 121.8\left(\mathrm{~s}+\mathrm{s}, \mathrm{C} 4+\mathrm{C}^{\prime}\right), 119.9\left(\mathrm{~s}, \mathrm{C}^{\prime}\right), 119.6(\mathrm{~s}$, $\mathrm{C} 5), 58.8(\mathrm{~s}, \mathrm{C} \alpha), 34.8\left(\mathrm{~s}, \mathrm{CMe}_{3}+\mathrm{CMe}_{3}{ }^{\prime}\right), 31.8\left(\mathrm{~s}, \mathrm{CMe}_{3}\right), 31.7$ (s, $\left.\mathrm{CMe}_{3}{ }^{\prime}\right), 24.2(\mathrm{~s}, \mathrm{C} \beta), 20.2(\mathrm{~s}, \mathrm{C} \gamma), 13.8 \mathrm{ppm}(\mathrm{s}, \mathrm{C} \delta) .{ }^{19} \mathrm{~F}$ NMR $\left(282.4 \mathrm{MHz}\right.$, THF- $d_{8}, 298 \mathrm{~K}, J$ values in $\left.\mathrm{Hz}\right)-116.6\left(\mathrm{~m},{ }^{3} J_{\mathrm{FF}}=23.0\right.$, $2 \mathrm{~F}, o-\mathrm{F}),-165.6(\mathrm{~m}, 3 \mathrm{~F}, p-\mathrm{F}+m-\mathrm{F}) .{ }^{1} \mathrm{H} \mathrm{NMR}(300.13 \mathrm{MHz}$, Toluene- $d_{8}, 298 \mathrm{~K}, J$ values in $\left.\mathrm{Hz}\right) \delta 8.31(\mathrm{~s}, 1 \mathrm{H}, \mathrm{H} 2), 7.41$ (br s, $\left.1 \mathrm{H}, \mathrm{H} 2^{\prime}\right), 7.34\left(\mathrm{~m}, 2 \mathrm{H}, \mathrm{H} 5+\mathrm{H} 5^{\prime}\right), 7.04$ (m, partially overlapped with toluene, $\left.\mathrm{H} 4+\mathrm{H} 4^{\prime}\right), 2.47$ (br m, $\left.8 \mathrm{H}, \mathrm{H} \alpha\right), 1.67$ (brs, $\left.1 \mathrm{H}, \mathrm{Au}-\mathrm{H}\right), 1.39$ $\left(\mathrm{s}, 9 \mathrm{H}, \mathrm{CMe}_{3}\right.$ ), 1.32 (brm, partially overlapped with THF and $\mathrm{BEt}_{3}$, $\mathrm{H} \beta$ ), 1.23 (s, $9 \mathrm{H}, \mathrm{CMe}_{3}{ }^{\prime}$ ), 0.99 (brm, partially overlapped with $\mathrm{BEt}_{3}$, $\mathrm{H} \gamma), 0.83 \mathrm{ppm}\left(\right.$ brt, ${ }^{3} J_{\mathrm{HH}}=7.3,9 \mathrm{H}, \mathrm{H} \delta$ ).

$\left[N B u_{4}\right]\left[\left(C^{\wedge} \mathrm{C}\right) \mathrm{Au}\left(\mathrm{Z}-\mathrm{C}_{2} \mathrm{H}\left(\mathrm{CO}_{2} \mathrm{Me}\right)_{2}\right) \mathrm{C}_{6} \mathrm{~F}_{5}\right]$ (17). A sample of $\left[\mathrm{NBu}_{4}\right]$ $\left[\left(\mathrm{C}^{\wedge} \mathrm{C}\right) \mathrm{Au}(\mathrm{H}) \mathrm{C}_{6} \mathrm{~F}_{5}\right]$ was generated from $10 \mathrm{mg}$ of $\left(\mathrm{C}^{\wedge} \mathrm{C}\right) \mathrm{AuCl}(\mathrm{py})$ in THF- $d_{8}$ and treated with 2 equiv of DMAD at room temperature to give a bright orange solution. Conversion into the vinyl product was instantaneous, as indicated by ${ }^{1} \mathrm{H}$ NMR. The THF solution was then passed through silica, dried and washed with light petroleum ether to remove most of borane and DMAD impurities. ${ }^{1} \mathrm{H}$ NMR $\left(300.13 \mathrm{MHz}, \mathrm{THF}-d_{8}, 298 \mathrm{~K}, J\right.$ values in $\left.\mathrm{Hz}\right) \delta 7.59\left(\mathrm{~d},{ }^{4} J_{\mathrm{HH}}=2.1\right.$, $1 \mathrm{H}, \mathrm{H} 2), 7.26$ (s, 1H, H8), $7.21\left(\mathrm{~m}, 2 \mathrm{H}, \mathrm{H} 5+\mathrm{H}^{\prime}\right), 6.97(\mathrm{~m}, 3 \mathrm{H}$, $\left.\mathrm{H}^{\prime}+\mathrm{H} 4+\mathrm{H}^{\prime}\right), 3.52$ (s, 3H, H10), $3.48(\mathrm{~s}, 3 \mathrm{H}, \mathrm{H} 12), 3.02(\mathrm{~m}, 8 \mathrm{H}$, $\mathrm{H} \alpha), 1.43(\mathrm{~m}, 8 \mathrm{H}, \mathrm{H} \beta), 1.23\left(\mathrm{~s}, 9 \mathrm{H}, \mathrm{CMe}_{3}\right), 1.19\left(\mathrm{q}, 8 \mathrm{H},{ }^{3} J_{\mathrm{HH}}=7.4\right.$, $\mathrm{H} \gamma), 1.13\left(\mathrm{~s}, 9 \mathrm{H}, \mathrm{CMe}_{3}{ }^{\prime}\right), 0.9 \mathrm{ppm}\left(\mathrm{t}, 9 \mathrm{H},{ }^{3} J_{\mathrm{HH}}=7.4, \mathrm{H} \delta\right) .{ }^{13} \mathrm{C}\left\{{ }^{1} \mathrm{H}\right\}$
NMR (75.47 MHz, THF- $\left.d_{8}, 298 \mathrm{~K}\right) \delta 184.7$ (s, C7), 175.0 (s, C9), 169.2 (s, C11), 159.8 (s, C1'), 159.2 (brs, C1), 153.3 (s, C6 '), 152.7 (s, C6), 147.6 (s, C3), 147.2 (s, C3'), $132.8\left(\mathrm{~s}, \mathrm{C} 2^{\prime}\right), 132.4$ (s, C2), 126.4 (s, C8), 121.6 (s, C4), 121.1 (s, C4'), $119.2\left(\mathrm{~s}, \mathrm{C} 5^{\prime}\right), 118.8$ (s, C5), 57.7 (s, C $\alpha), 50.1$ (s, C10), $49.8(\mathrm{~s}, \mathrm{C} 12), 34.4\left(\mathrm{~s}, \mathrm{CMe}_{3}\right), 34.0$ (s, $\left.\mathrm{CMe}_{3}{ }^{\prime}\right), 31.0\left(\mathrm{~s}, \mathrm{CMe}_{3}\right), 30.9\left(\mathrm{~s}, \mathrm{CMe}_{3}{ }^{\prime}\right), 23.6(\mathrm{~s}, \mathrm{C} \beta), 19.4$ (s, $\mathrm{C} \gamma), 13.1 \mathrm{ppm}(\mathrm{s}, \mathrm{C} \delta) .{ }^{19} \mathrm{~F}$ NMR $\left(282.4 \mathrm{MHz}, \mathrm{THF}-d_{8}, 298 \mathrm{~K}, J\right.$ values in $\mathrm{Hz})-116.4\left(\mathrm{dm},{ }^{3} \mathrm{~J}_{\mathrm{FF}}=34.1,1 \mathrm{~F}, o-\mathrm{F}\right),-117.2\left(\mathrm{dm},{ }^{3} \mathrm{~J}_{\mathrm{FF}}=\right.$ $34.1,1 \mathrm{~F}, o-\mathrm{F}),-165.2\left(\mathrm{t},{ }^{3} \mathrm{JFF}_{\mathrm{FF}}=19.8,1 \mathrm{~F}, p-\mathrm{F}\right),-166-0(\mathrm{~m}, 2 \mathrm{H}$, $o-\mathrm{F}) .{ }^{1} \mathrm{H}$ NMR $\left(300.13 \mathrm{MHz}, \mathrm{CD}_{2} \mathrm{Cl}_{2}, 298 \mathrm{~K}, J\right.$ values in $\left.\mathrm{Hz}\right) \delta$ $7.58\left(\mathrm{~d},{ }^{4} \mathrm{~J}_{\mathrm{HH}}=1.6,1 \mathrm{H}, \mathrm{H} 2\right), 7.28\left(\mathrm{~m}, 3 \mathrm{H}, \mathrm{H} 5+\mathrm{H} 5^{\prime}+\mathrm{H} 8\right), 7.04(\mathrm{dd}$, $\left.{ }^{3} J_{\mathrm{HH}}=8.1{ }^{4} J_{\mathrm{HH}}=1.8,2 \mathrm{H}, \mathrm{H} 4+\mathrm{H} 4^{\prime}\right), 3.6(\mathrm{~s}, 3 \mathrm{H}, \mathrm{H} 12), 3.54(\mathrm{~s}, 3 \mathrm{H}$, $\mathrm{H} 10), 2.85(\mathrm{~m}, \mathrm{H} \alpha), 1.33(\mathrm{~m}, \mathrm{H} \beta), 1.24\left(\mathrm{~s}, 9 \mathrm{H}, \mathrm{CMe}_{3}\right), 1.18$ (m, $\mathrm{H} \gamma), 1.13\left(\mathrm{~s}, 9 \mathrm{H}, \mathrm{CMe}_{3}{ }^{\prime}\right), 0.91 \mathrm{ppm}\left(\mathrm{t},{ }^{3} \mathrm{~J}_{\mathrm{HH}}=7.3, \mathrm{H} \delta\right)$.

$\mathrm{Li}\left[(\mathrm{C} \wedge \mathrm{C}) \mathrm{Au}\left(\mathrm{Z}-\mathrm{C}_{2} \mathrm{H}\left(\mathrm{CO}_{2} \mathrm{Me}\right) \mathrm{CH}_{2} \mathrm{OBEt}{ }_{3}\left(\mathrm{PMe}_{3}\right)\right]\right.$ (18). A sample of 12 was generated in situ in THF- $d_{8}$ and treated at room temperature with aliquots of $\mathrm{LiHBEt}_{3}$ until reaching a Au/hydride stoichiometric ratio of 2.5. Full conversion of $\mathbf{1 2}$ into $\mathbf{1 8}$ was observed immediately. ${ }^{1} \mathrm{H}$ NMR (300.13 MHz, THF- $d_{8}, 298 \mathrm{~K}, J$ values in $\left.\mathrm{Hz}\right) \delta 7.93(\mathrm{~m}$, $1 \mathrm{H}, \mathrm{H} 8), 7.62\left(\mathrm{dd},{ }^{4} J_{\mathrm{PH}}=9.7,{ }^{4} J_{\mathrm{HH}}=1.6,1 \mathrm{H}, \mathrm{H} 2\right), 7.55$ (brs, $1 \mathrm{H}$, $\left.\mathrm{H} 2^{\prime}\right), 7.32\left(\mathrm{~d},{ }^{3} J_{\mathrm{HH}}=8.1,1 \mathrm{H}, \mathrm{H} 5^{\prime}\right), 7.25\left(\mathrm{dd},{ }^{3} J_{\mathrm{HH}}=8.0,{ }^{5} J_{\mathrm{PH}}=4.1\right.$, $1 \mathrm{H}, \mathrm{H} 5), 7.09\left(\mathrm{dd},{ }^{3} J_{\mathrm{HH}}=8.1,{ }^{4} \mathrm{~J}_{\mathrm{HH}}=1.6,1 \mathrm{H}, \mathrm{H} 4^{\prime}\right), 7.03\left(\mathrm{br} \mathrm{d},{ }^{3} J_{\mathrm{HH}}\right.$ $=8.0,1 \mathrm{H}, \mathrm{H} 4), 3.01\left(\mathrm{br} \mathrm{d},{ }^{3} J_{\mathrm{HH}}=4.3,2 \mathrm{H}, \mathrm{H} 9\right), 3.59$ (buried under THF, H11), 1.81 (partially overlapped with THF, $\mathrm{PMe}_{3}$ ), 1.33 (s, $\left.9 \mathrm{H}, \mathrm{CMe}_{3}{ }^{\prime}\right), 1.24\left(\mathrm{~s}, 9 \mathrm{H}, \mathrm{CMe}_{3}\right.$ ), 0.66 (br t, overlapped with $\mathrm{BEt}_{3}$, $\left.\mathrm{O}-\mathrm{BCH}_{2} \mathrm{CH}_{3}\right), 0.00 \mathrm{ppm}$ (br t, overlapped with $\mathrm{BEt}_{3}, \mathrm{O}-$ $\left.\mathrm{BCH}_{2} \mathrm{CH}_{3}\right) .{ }^{13} \mathrm{C}\left\{{ }^{1} \mathrm{H}\right\}$ NMR $\left(75.47 \mathrm{MHz}\right.$, THF- $d_{8}, 298 \mathrm{~K}, J$ values in $\mathrm{Hz}) \delta 174.0(\mathrm{~s}, \mathrm{C} 7), 163.2\left(\mathrm{~d},{ }^{2} \mathrm{~J}_{\mathrm{PC}}=6.2, \mathrm{Cl}^{\prime}\right), 159.8\left(\mathrm{~d},{ }^{2} \mathrm{~J}_{\mathrm{PC}}=\right.$ 138.7, C1), $159.7\left(\mathrm{~d},{ }^{3} \mathrm{~J}_{\mathrm{PC}}=14.6, \mathrm{C} 10\right), 154.2\left(\mathrm{~d},{ }^{3} \mathrm{~J}_{\mathrm{PC}}=5.4, \mathrm{C}^{\prime}\right)$, $153.6(\mathrm{~s}, \mathrm{C} 6), 149.9(\mathrm{~s}, \mathrm{C} 8), 148.6\left(\mathrm{~s}, \mathrm{C} 3{ }^{\prime}\right), 148.5\left(\mathrm{~s},{ }^{4} J_{\mathrm{PC}}=9.9\right.$, C3), $132.5\left(\mathrm{~d},{ }^{3} \mathrm{~J}_{\mathrm{PC}}=7.1, \mathrm{C} 2{ }^{\prime}\right), 132.4(\mathrm{~s}, \mathrm{C} 2), 123.4(\mathrm{~s}, \mathrm{C} 4), 123.2$ (s, C4'), $120.6\left(\mathrm{~m}, \mathrm{C} 5+\mathrm{C} 5^{\prime}\right), 64.7$ (s, C9), 51.1 (s, C11), 35.2 (s, $\mathrm{CMe}_{3}$ ), 35.1 (s, $\left.\mathrm{CMe}_{3}{ }^{\prime}\right), 31.8\left(\mathrm{~s}, \mathrm{CMe}_{3}{ }^{\prime}\right), 31.7$ (s, $\left.\mathrm{CMe}_{3}\right), 14.0$ (d, $\left.{ }^{1} J_{\mathrm{PC}}=31.6, \mathrm{PMe}_{3}\right), 13.9$ (brs, overlapped with $\mathrm{PMe}_{3}, \mathrm{O}-\mathrm{BCH}_{2} \mathrm{CH}_{3}$ ), 10.9 ppm (overlapped with $\mathrm{BEt}_{3}, \mathrm{O}-\mathrm{BCH}_{2} \mathrm{CH}_{3}$ ).

Z-Dimethyl(3-tbutyl(6-(4-tbutylphenyl))phenyl)fumarate (19). A sample of 12 was generated in THF- $d_{8}$ and treated at room temperature with substoichiometric portions of $\left[\mathrm{H}\left(\mathrm{OEt}_{2}\right)_{2}\right]\left[\mathrm{H}_{2} \mathrm{~N}\{\mathrm{~B}\right.$ $\left.\left.\left(\mathrm{C}_{6} \mathrm{~F}_{5}\right)_{3}\right\}_{2}\right]$ until reacting a stoichiometric ratio of acid/Au of 1.2. Upon addition of the acid, the deep orange color of $\mathbf{1 2}$ faded to give a pale-yellow solution and the formation of a dark precipitate. ${ }^{1} \mathrm{H}$ NMR spectroscopy revealed the complete disappearance of 12 to give 19 in $65 \%$ yield. NMR characterization is given in mixture.

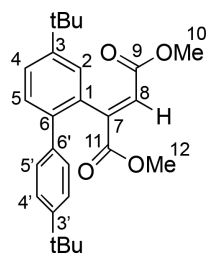

${ }^{1} \mathrm{H}$ NMR $\left(300.13 \mathrm{MHz}\right.$, THF- $d_{8}, 298 \mathrm{~K}, J$ values in $\left.\mathrm{Hz}\right) \delta 7.43$ $\left(\mathrm{dd},{ }^{3} \mathrm{~J}_{\mathrm{HH}}=8.1,{ }^{4} \mathrm{~J}_{\mathrm{HH}}=2.0,1 \mathrm{H}, \mathrm{H} 4\right), 7.34\left(\mathrm{~d},{ }^{3} \mathrm{~J}_{\mathrm{HH}}=8.5,2 \mathrm{H}, \mathrm{H} 4{ }^{\prime}\right)$, $7.24(\mathrm{~m}, 2 \mathrm{H}, \mathrm{H} 5+\mathrm{H} 8), 7.20\left(\mathrm{~d},{ }^{3} \mathrm{~J}_{\mathrm{HH}}=8.5,2 \mathrm{H}, \mathrm{H} 5^{\prime}\right), 6.83(\mathrm{~s}, \mathrm{H} 8)$, 3.54 (s, 3H, H12), 3.3 (s, 3H, H10), 1.34 (s, 9H, $\mathrm{CMe}_{3}$ ), $1.32 \mathrm{ppm}$ (s, 9H, CMe $\left.{ }^{\prime}\right)$. Partial ${ }^{13} \mathrm{C}\left\{{ }^{1} \mathrm{H}\right\}$ NMR (75.47 MHz, THF- $d_{8}, 298 \mathrm{~K}$ ) $\delta 165.8$ (s, C9), 165.4 (s, C11), 149.7 (overlapped with $\mathrm{AB}_{2}, \mathrm{C}^{\prime}$ ), 149.4 (s, C3), 138.8 (overlapped with $\mathrm{AB}_{2}, \mathrm{C}^{\prime}+\mathrm{C} 6$ ), 133.0 (s, C1), 128.9 (s, C8), 128.8 (s, C5), 128.7 (s, C5'), 127.3 (s, C8), 125.4 (s, C4), 124.5 (s, C4'), 51.2 (s, C10), 50.8 (s, C12), 34.7 (s+s, $\mathrm{CMe}_{3}+\mathrm{CMe}_{3}{ }^{\prime}$ ), $30.7 \mathrm{ppm}$ (s, $\mathrm{CMe}_{3}+\mathrm{CMe}_{3}{ }^{\prime}$ ).

$[(C \wedge N-C H) A u H(\mu-H) A u(C \wedge N \wedge C)]\left[A B_{2}\right]$ (20). Within the glovebox, $15 \mathrm{mg}$ of $\left(\mathrm{C}^{\wedge} \mathrm{N}^{\wedge} \mathrm{C}\right) \mathrm{AuH}$ were loaded into a screw-cap NMR tube and dissolved in approximately $0.3 \mathrm{~mL}$ of dry $\mathrm{CD}_{2} \mathrm{Cl}_{2}$. One equiv $\left[\mathrm{H}\left(\mathrm{OEt}_{2}\right)_{2}\right]\left[\mathrm{H}_{2} \mathrm{~N}\left\{\mathrm{~B}\left(\mathrm{C}_{6} \mathrm{~F}_{5}\right)_{3}\right\}_{2}\right](33.1 \mathrm{mg}, 0.028 \mathrm{mmol})$ was dissolved in $0.4 \mathrm{~mL}$ of dry $\mathrm{CD}_{2} \mathrm{Cl}_{2}$ and loaded into a gastight syringe equipped with a rubber stopper. Outside the glovebox, the NMR tube was inserted into a cold bath at $198 \mathrm{~K}$ and the acid solution was slowly injected through the septum at low temperature. The sample was 
then shaken quickly, inserted in the precooled NMR probe and studied at $213 \mathrm{~K}$. Extensive decomposition was observed after $1 \mathrm{~h}$ at $213 \mathrm{~K} .{ }^{1} \mathrm{H}$ NMR $\left(300.13 \mathrm{MHz}, \mathrm{CD}_{2} \mathrm{Cl}_{2}, 213 \mathrm{~K}, J\right.$ values in $\left.\mathrm{Hz}\right) \delta$ $8.23\left(\mathrm{t},{ }^{3} J_{\mathrm{HH}}=8.0,1 \mathrm{H}, \mathrm{H} 1\right), 8.08\left(\mathrm{~d},{ }^{3} J_{\mathrm{HH}}=8.0,1 \mathrm{H}, \mathrm{H} 2\right), 7.79(\mathrm{~m}$, $\left.3 \mathrm{H}, \mathrm{H} 5+\mathrm{H} 2^{\prime}+\mathrm{H} 1 \mathrm{a}\right), 7.60(\mathrm{~m}, 2 \mathrm{H}, \mathrm{H} 6+\mathrm{H} 8), 7.38\left(\mathrm{~m}, 8 \mathrm{H}, \mathrm{H} 5^{\prime}+\mathrm{H} 2 \mathrm{a}\right.$ $+\mathrm{H} 5 \mathrm{a}+\mathrm{H} 6 \mathrm{a}), 7.17\left(\mathrm{~m}, 4 \mathrm{H}, \mathrm{H6}^{\prime}+\mathrm{H} 8 \mathrm{a}\right), 5.56\left(\mathrm{br} \mathrm{s}, \mathrm{NH}_{2}\right), 1.13(\mathrm{~s}, 9 \mathrm{H}$, $\left.\mathrm{CMe}_{3}\right), 1.03\left(\mathrm{~s}, 18 \mathrm{H}, \mathrm{CMe}_{3} \mathrm{a}\right), 0.81\left(\mathrm{~s}, 9 \mathrm{H}, \mathrm{CMe}_{3}{ }^{\prime}\right),-4.93\left(\mathrm{~d},{ }^{2} J_{\mathrm{HH}}=\right.$ 8.6, $1 \mathrm{H}, \mathrm{Hb}),-8.47 \mathrm{ppm}\left(\right.$ br d, $\left.{ }^{2} \mathrm{~J}_{\mathrm{HH}}=8.6,1 \mathrm{H}, \mathrm{Ha}\right)$.

$[(C \wedge N-C H) A u M e(\mu-H) A u(C \wedge N \wedge C)]\left[A B_{2}\right]$ (21). Ten mg of $\left(\mathrm{C}^{\wedge} \mathrm{N}^{\wedge} \mathrm{C}\right) \mathrm{AuMe}$ and 1.0 equiv of $\left[\mathrm{H}\left(\mathrm{OEt}_{2}\right)_{2}\right]\left[\mathrm{H}_{2} \mathrm{~N}\left\{\mathrm{~B}\left(\mathrm{C}_{6} \mathrm{~F}_{5}\right)_{3}\right\}_{2}\right]$ were loaded within a screw cap NMR and dissolved in approximately $0.5 \mathrm{~mL}$ of $\mathrm{CD}_{2} \mathrm{Cl}_{2}$. Outside the glovebox, the NMR sample was inserted in a cold bath at $195 \mathrm{~K}$ and 1.0 equiv $\left(\mathrm{C}^{\wedge} \mathrm{N}^{\wedge} \mathrm{C}\right) \mathrm{AuH}(9.7$ $\mathrm{mg}, 0.018 \mathrm{mmol}$, dissolved in $0.3 \mathrm{~mL}$ of $\mathrm{CD}_{2} \mathrm{Cl}_{2}$ ) were injected through the septum to give a bright yellow solution, which was quickly shaken and inserted into the precooled NMR probe at 213 K. 21 was observed in $65 \%$ yield, along with unreacted 3a. Partial ${ }^{1} \mathrm{H}$ NMR (300.13 MHz, $\mathrm{CD}_{2} \mathrm{Cl}_{2}, 243 \mathrm{~K}, J$ values in $\left.\mathrm{Hz}\right) 8.21(\mathrm{~m}, 2 \mathrm{H}$, $\mathrm{H} 1+\mathrm{H} 2), 7.89\left(\mathrm{~m}, 2 \mathrm{H}, \mathrm{H} 1 \mathrm{a}+\mathrm{H} 2^{\prime}\right), 7.72$ (br d, overlapped with $3 \mathrm{a}$, $\mathrm{H} 5), 7.50\left(\mathrm{br} \mathrm{d},{ }^{3} \mathrm{~J}_{\mathrm{HH}}=8.1,1 \mathrm{H}, \mathrm{H} 6\right), 7.43\left(\mathrm{~m}, 6 \mathrm{H}, \mathrm{H} 2 \mathrm{a}+\mathrm{H} 5 \mathrm{a}+\mathrm{H} 5^{\prime}\right)$, 7.34 (br s, 4H, H8a+H6'), 7.27 (s, overlapped with 3a, H8), 7.20 (d, $\left.{ }^{3} J_{\mathrm{HH}}=8.1, \mathrm{H} 6 \mathrm{a}\right), 5.62\left(\mathrm{br} \mathrm{s}, \mathrm{NH}_{2}\right), 1.71(\mathrm{~s}, 3 \mathrm{H}, \mathrm{Au}-\mathrm{Me}), 1.26(\mathrm{~s}$, 9H, $\mathrm{CMe}_{3}$ ), 1.08 (s, overlapped with $\mathrm{Et}_{2} \mathrm{O}, \mathrm{CMe}_{3} \mathrm{a}$ ), 0.76 (s, 9H, $\left.\mathrm{CMe}_{3}{ }^{\prime}\right),-5.14 \mathrm{ppm}(\mathrm{s}, 1 \mathrm{H}, \mathrm{Au}-\mathrm{H}-\mathrm{Au})$.

$[(C \wedge N-C H) A u M e(\mu-H) M e A u(C \wedge N-C H)]\left[A B_{2}\right]$ (22a). Fifteen mg of $\left(\mathrm{C}^{\wedge} \mathrm{N}^{\wedge} \mathrm{C}\right) \mathrm{AuMe}$ and 1.0 equiv of $\left[\mathrm{H}\left(\mathrm{OEt}_{2}\right)_{2}\right]\left[\mathrm{H}_{2} \mathrm{~N}\left\{\mathrm{~B}\left(\mathrm{C}_{6} \mathrm{~F}_{5}\right)_{3}\right\}_{2}\right]$ were loaded within a screw cap NMR and dissolved in approximately $0.6 \mathrm{~mL}$ of $\mathrm{CD}_{2} \mathrm{Cl}_{2}$. Outside the glovebox, the NMR sample was inserted in a cold bath at $195 \mathrm{~K}$ and 5.0 equiv of $\mathrm{HSi}(\mathrm{OMe})_{3}$ were injected through the septum. The sample was quickly shaken and inserted in the precooled NMR probe at $243 \mathrm{~K} .{ }^{1} \mathrm{H}$ NMR (300.13 $\mathrm{MHz}, \mathrm{CD}_{2} \mathrm{Cl}_{2}, 243 \mathrm{~K}, J$ values in $\left.\mathrm{Hz}\right) \delta 8.18\left(\mathrm{t},{ }^{3} J_{\mathrm{HH}}=7.8,2 \mathrm{H}, \mathrm{H1}\right)$, $8.06\left(\mathrm{~d},{ }^{3} \mathrm{~J}_{\mathrm{HH}}=7.8,2 \mathrm{H}, \mathrm{H} 2\right), 7.76\left(\mathrm{~d},{ }^{3} J_{\mathrm{HH}}=8.2,2 \mathrm{H}, \mathrm{H} 5\right), 7.46(\mathrm{~d}$, $\left.{ }^{3} J_{\mathrm{HH}}=7.8,2 \mathrm{H}, \mathrm{H} 2^{\prime}\right), 7.42\left(\mathrm{~d},{ }^{3} J_{\mathrm{HH}}=8.2,2 \mathrm{H}, \mathrm{H} 6\right), 7.33(\mathrm{br} \mathrm{m}, 4 \mathrm{H}$, $\left.\mathrm{H} 8+\mathrm{H}^{\prime a}\right), 7.21\left(\mathrm{~d},{ }^{3} \mathrm{~J}_{\mathrm{HH}}=8.4,2 \mathrm{H}, \mathrm{H}^{\prime a}\right), 6.77\left(\mathrm{~d},{ }^{3} J_{\mathrm{HH}}=8.2,2 \mathrm{H}\right.$, $\left.\mathrm{H}^{\prime{ }^{\prime b}}\right), 6.55\left(\mathrm{~d},{ }^{3} J_{\mathrm{HH}}=8.2,2 \mathrm{H}, \mathrm{H}^{\prime \mathrm{b}}\right), 5.66\left(\mathrm{br} \mathrm{s}, 2 \mathrm{H}, \mathrm{NH}_{2}\right), 1.35(\mathrm{~s}$, $3 \mathrm{H}, \mathrm{Au}-\mathrm{Me}), 1.31\left(\mathrm{~s}, 18 \mathrm{H}, \mathrm{CMe}_{3}\right), 0.75\left(\mathrm{~s}, 18 \mathrm{H}, \mathrm{CMe}_{3}{ }^{\prime}\right),-2.53$ ppm (s, $1 \mathrm{H}, \mathrm{Au}-\mathrm{H}-\mathrm{Au}) \cdot{ }^{13} \mathrm{C}\left\{{ }^{1} \mathrm{H}\right\}$ NMR $\left(75.47 \mathrm{MHz}, \mathrm{CD}_{2} \mathrm{Cl}_{2}, 223\right.$ $\mathrm{K}, J$ values in $\mathrm{Hz}) \delta 161.2(\mathrm{~s}, \mathrm{C} 3), 160.3\left(\mathrm{~s}, \mathrm{C}^{\prime}\right), 154.9(\mathrm{~s}, \mathrm{C} 7)$, 154.1 (s, C9), $153.5\left(\mathrm{~s}, \mathrm{C}^{\prime}\right), 147.5\left(\mathrm{br} \mathrm{d},{ }^{1} J_{\mathrm{CF}}=238.5, o-\mathrm{F}\right.$ $\left.\mathrm{H}_{2} \mathrm{~N}\left[\mathrm{~B}\left(\mathrm{C}_{6} \mathrm{~F}_{5}\right)_{3}\right]_{2}{ }^{-}\right), 141.8$ (s, C1), 141.2 (s, C4), 138.9 (br d, ${ }^{1} J_{\mathrm{CF}}=$ 250.0, p-F $\left.\mathrm{H}_{2} \mathrm{~N}\left[\mathrm{~B}\left(\mathrm{C}_{6} \mathrm{~F}_{5}\right)_{3}\right]_{2}{ }^{-}\right), 136.5\left(\mathrm{br} \mathrm{d},{ }^{1} J_{\mathrm{CF}}=250.0, m-\mathrm{F}\right.$ $\left.\mathrm{H}_{2} \mathrm{~N}\left[\mathrm{~B}\left(\mathrm{C}_{6} \mathrm{~F}_{5}\right)_{3}\right]_{2}^{-}\right), \quad 137.2\left(\mathrm{~s}, \mathrm{C}^{\prime}\right), \quad 130.7\left(\mathrm{~s}, \mathrm{CF}^{\prime \mathrm{a}}\right), 127.2(\mathrm{~s}$, $\mathrm{C} 8+\mathrm{C} 5), 126.2(\mathrm{~s}, \mathrm{C} 6), 125.7\left(\mathrm{~s}+\mathrm{s}, \mathrm{C}^{\mathrm{b}}+\mathrm{C}^{\prime \mathrm{a}}\right), 125.2\left(\mathrm{~s}, \mathrm{C}^{\prime \mathrm{b}}\right)$, $124.4\left(\mathrm{~s}, \mathrm{C2}^{\prime}\right), 118.8$ (s, C2), 35.7 (s, $\left.\mathrm{CMe}_{3}\right), 34.3\left(\mathrm{~s}, \mathrm{CMe}_{3}{ }^{\prime}\right), 30.9$ (s, $\left.\mathrm{CMe}_{3}\right), 30.2\left(\mathrm{~s}, \mathrm{CMe}_{3}{ }^{\prime}\right), 10.0 \mathrm{ppm}(\mathrm{s}, \mathrm{Au}-\mathrm{Me})$.

$\left[(C \wedge N-C H) A u C_{6} F_{5}(\mu-H) A u\left(F_{5} C_{6}\right)(C \wedge N-C H)\right]\left[A B_{2}\right] \quad$ (22b). Fifteen $\mathrm{mg}$ of $\left(\mathrm{C}^{\wedge} \mathrm{N}^{\wedge} \mathrm{C}\right) \mathrm{AuC}_{6} \mathrm{~F}_{5}$ and 1.0 equiv $\left[\mathrm{H}\left(\mathrm{OEt}_{2}\right)_{2}\right]\left[\mathrm{H}_{2} \mathrm{~N}\{\mathrm{~B}\right.$ $\left.\left.\left(\mathrm{C}_{6} \mathrm{~F}_{5}\right)_{3}\right\}_{2}\right]$ were loaded within a screw-cap $\mathrm{NMR}$ and dissolved in approximately $0.6 \mathrm{~mL}$ of $\mathrm{CD}_{2} \mathrm{Cl}_{2}$. Outside the glovebox, the NMR sample was inserted in a cold bath at $195 \mathrm{~K}$ and 5.0 equiv $\mathrm{HSi}(\mathrm{OMe})_{3}$ were injected through the septum. The sample was quickly shaken and inserted in the precooled NMR probe at $223 \mathrm{~K}$. ${ }^{1} \mathrm{H}$ NMR $\left(300.13 \mathrm{MHz}, \mathrm{CD}_{2} \mathrm{Cl}_{2}, 223 \mathrm{~K}, J\right.$ values in $\left.\mathrm{Hz}\right) \delta 8.34(\mathrm{t}$, $\left.{ }^{3} J_{\mathrm{HH}}=7.8,2 \mathrm{H}, \mathrm{H} 1\right), 8.13\left(\mathrm{~d},{ }^{3} J_{\mathrm{HH}}=7.8,2 \mathrm{H}, \mathrm{H} 2\right), 7.78\left(\mathrm{~d},{ }^{3} \mathrm{~J}_{\mathrm{HH}}=\right.$ $8.2,2 \mathrm{H}, \mathrm{H} 5), 7.56\left(\mathrm{~d},{ }^{3} J_{\mathrm{HH}}=7.8,2 \mathrm{H}, \mathrm{H} 2^{\prime}\right), 7.50(\mathrm{~m}, 4 \mathrm{H}$, $\left.\mathrm{H}^{\prime 2}+\mathrm{H}^{\prime 2}{ }^{\prime a}\right), 7.38\left(\mathrm{~d},{ }^{3} \mathrm{~J}_{\mathrm{HH}}=8.2,2 \mathrm{H}, \mathrm{H} 6\right), 7.07\left(\mathrm{~d},{ }^{3} J_{\mathrm{HH}}=8.3,2 \mathrm{H}\right.$, $\left.\mathrm{H}^{\prime}{ }^{\mathrm{b}}\right), 6.33\left(\mathrm{~d},{ }^{3} \mathrm{JH}_{\mathrm{HH}}=8.3,2 \mathrm{H}, \mathrm{H}^{\prime \mathrm{b}}\right), 6.07(\mathrm{~s}, 2 \mathrm{H}, \mathrm{H} 8), 5.64(\mathrm{br} \mathrm{s}$, $\left.4 \mathrm{H}, \mathrm{NH}_{2}\right), 1.00\left(\mathrm{~s}, 18 \mathrm{H}, \mathrm{CMe}_{3}\right), 0.82\left(\mathrm{~s}, 18 \mathrm{H}, \mathrm{CMe}_{3}{ }^{\prime}\right),-2.21 \mathrm{ppm}$ (s, $1 \mathrm{H}, \mathrm{Au}-\mathrm{H}-\mathrm{Au}) .{ }^{13} \mathrm{C}\left\{{ }^{1} \mathrm{H}\right\}$ NMR $\left(75.47 \mathrm{MHz}, \mathrm{CD}_{2} \mathrm{Cl}_{2}, 223 \mathrm{~K}, J\right.$ values in $\mathrm{Hz}$ ) $\delta 162.2$ (s, C3), $160.3\left(\mathrm{~s}, \mathrm{C}^{\prime}\right), 159.5$ (s, C9), 156.5 $(\mathrm{s}, \mathrm{C} 7), 154.8\left(\mathrm{~s}, \mathrm{C} 7^{\prime}\right), 147.5\left(\mathrm{br} d,{ }^{1} J_{\mathrm{CF}}=239.8, \quad o-\mathrm{F}\right.$ $\left.\mathrm{H}_{2} \mathrm{~N}\left[\mathrm{~B}\left(\mathrm{C}_{6} \mathrm{~F}_{5}\right)_{3}\right]_{2}{ }^{-}\right), 143.3$ (s, C1), 138.9 (s, C4), 138.8 (br d, ${ }^{1} J_{\mathrm{CF}}$

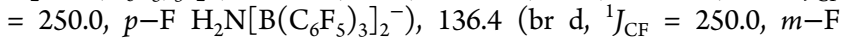
$\left.\mathrm{H}_{2} \mathrm{~N}\left[\mathrm{~B}\left(\mathrm{C}_{6} \mathrm{~F}_{5}\right)_{3}\right]_{2}{ }^{-}\right), 134.9\left(\mathrm{~s}, \mathrm{C}^{\prime}\right), 130.0\left(\mathrm{~s}, \mathrm{C}^{\prime \mathrm{a}}\right), 129.4$ (s, C8), $128.2(\mathrm{~s}, \mathrm{C} 5), 127.9\left(\mathrm{~s}, \mathrm{C}^{\prime a}\right), 127.5\left(\mathrm{~s}, \mathrm{C}^{\prime \mathrm{b}}\right), 127.2(\mathrm{~s}, \mathrm{C} 6), 126.2$ $\left(\mathrm{s}, \mathrm{C}^{\prime}\right), 125.7\left(\mathrm{~s}, \mathrm{CF}^{\prime \mathrm{b}}\right), 119.5(\mathrm{~s}, \mathrm{C} 2), 35.5\left(\mathrm{~s}, \mathrm{CMe}_{3}\right), 34.7(\mathrm{~s}$, $\left.\mathrm{CMe}_{3}{ }^{\prime}\right), 30.5$ (s, $\left.\mathrm{CMe}_{3}\right), 29.9 \mathrm{ppm}\left(\mathrm{s}, \mathrm{CMe}_{3}{ }^{\prime}\right) .{ }^{19} \mathrm{~F}$ NMR (282.4 $\mathrm{MHz}, \mathrm{CD}_{2} \mathrm{Cl}_{2}, 223 \mathrm{~K}, J$ values in $\left.\mathrm{Hz}\right)-118.2\left(\mathrm{dq},{ }^{3} J_{\mathrm{FF}}=25.7{ }^{4} J_{\mathrm{FF}}=\right.$
6.0, $\left.1 \mathrm{~F}, o-\mathrm{F} \mathrm{Au}-\mathrm{C}_{6} \mathrm{~F}_{5}\right),-119.7\left(\mathrm{~d}\right.$ ps t, ${ }^{3} J_{\mathrm{FF}}=27.7{ }^{4} J_{\mathrm{FF}}=6.4,1 \mathrm{~F}$, $\left.o-\mathrm{F} \mathrm{Au}-\mathrm{C}_{6} \mathrm{~F}_{5}\right),-133.2$ (br s, $\left.12 \mathrm{~F}, o-\mathrm{F} \mathrm{H}_{2} \mathrm{~N}\left[\mathrm{~B}\left(\mathrm{C}_{6} \mathrm{~F}_{5}\right)_{3}\right]_{2}{ }^{-}\right),-154.8$ $\left(\mathrm{t},{ }^{3} J_{\mathrm{FF}}=21.0,1 \mathrm{~F}, p-\mathrm{F} \mathrm{Au}-\mathrm{C}_{6} \mathrm{~F}_{5}\right),-159.4\left(\mathrm{t},{ }^{3} J_{\mathrm{FF}}=21.1,1 \mathrm{~F}, p-\mathrm{F}\right.$ $\left.\mathrm{H}_{2} \mathrm{~N}\left[\mathrm{~B}\left(\mathrm{C}_{6} \mathrm{~F}_{5}\right)_{3}\right]_{2}{ }^{-}\right),-160.1\left(\mathrm{~m}, 1 \mathrm{~F}, m-\mathrm{F} \mathrm{Au}-\mathrm{C}_{6} \mathrm{~F}_{5}\right),-164.9 \mathrm{ppm}$ (brm, 13F, $m-\mathrm{F} \mathrm{Au}-\mathrm{C}_{6} \mathrm{~F}_{5}+m-\mathrm{F} \mathrm{H}_{2} \mathrm{~N}\left[\mathrm{~B}\left(\mathrm{C}_{6} \mathrm{~F}_{5}\right)_{3}\right]_{2}^{-}$).

\section{ASSOCIATED CONTENT}

\section{Supporting Information}

The Supporting Information is available free of charge on the ACS Publications website at DOI: 10.1021/jacs.8b04478.

Experimental details, characterization, crystallographic data, NMR spectra, and computational details (PDF) $\mathrm{X}$-ray crystallographic details (CIF)

Cartesian coordinates of the selected DFT optimized structures (XYZ)

\section{AUTHOR INFORMATION}

\section{Corresponding Authors}

*l.rocchigiani@uea.ac.uk

*peter.hrobarik@uniba.sk

*m.bochmann@uea.ac.uk

ORCID $\odot$

Luca Rocchigiani: 0000-0002-2679-8407

Julio Fernandez-Cestau: 0000-0001-7663-6222

Isabelle Chambrier: 0000-0003-0090-1186

Peter Hrobárik: 0000-0002-6444-8555

Manfred Bochmann: 0000-0001-7736-5428

Notes

The authors declare no competing financial interest.

\section{ACKNOWLEDGMENTS}

This work was supported by the European Research Council. M.B. is an ERC Advanced Investigator Award holder (Grant No. 338944-GOCAT). P.H. gratefully acknowledges support from the Berlin DFG excellence cluster on Unifying Concepts in Catalysis (UniCat) as well as funding from the Slovak VEGA grant agency (Grants No. 1/0507/17 and 1/0712/18) and from the European Union's Horizon 2020 research and innovation programme under the Marie Skłodowska-Curie Grant Agreement No. 752285. We thank Prof. Cristina Nevado for helpful discussions. We are grateful to the EPSRC National Crystallographic Service, Southampton, UK, for collection of crystallographic data sets. ${ }^{41}$

\section{REFERENCES}

(1) (a) Norton, J. R.; Sowa, J. R. Chem. Rev. 2016, 116, 83158317. (b) Chem. Rev. 2016, 116, 8315-9000 (themed issue).

(2) Schmidbaur, H.; Raubenheimer, H. G.; Dobrzańska, L. Chem. Soc. Rev. 2014, 43, 345-380.

(3) (a) Wang, X.; Andrews, L. J. Am. Chem. Soc. 2001, 123, 1289912900. (b) Wang, X.; Andrews, L. Angew. Chem., Int. Ed. 2003, 42, 5201-5206. (c) Andrews, L.; Wang, X. J. Am. Chem. Soc. 2003, 125, 11751-11760. (d) Andrews, L. Chem. Soc. Rev. 2004, 33, 123-132.

(4) (a) Tsui, E. Y.; Müller, P.; Sadighi, J. P. Angew. Chem., Int. Ed. 2008, 47, 8937-8940. Hydride-bridged binuclear gold(I) phosphine complexes have also been reported: (b) Escalle, A.; Mora, G.; Gagosz, F.; Mézailles, N.; Le Goff, X. F.; Jean, Y.; Le Floch, P. Inorg. Chem. 2009, 48, 8415-8422.

(5) Roşca, D.-A.; Smith, D. A.; Hughes, D. L.; Bochmann, M. Angew. Chem., Int. Ed. 2012, 51, 10643-10646.

(6) Pintus, A.; Rocchigiani, L.; Fernandez-Cestau, J.; Budzelaar, P. H. M.; Bochmann, M. Angew. Chem., Int. Ed. 2016, 55, 1232112324. 
(7) Kleinhans, G.; Hansmann, M. M.; Guisado-Barrios, G.; Liles, D. C.; Bertrand, G.; Bezuidenhout, D. I. J. Am. Chem. Soc. 2016, 138, $15873-15876$

(8) (a) Roşca, D.-A.; Wright, J. A.; Hughes, D. L.; Bochmann, M. Nat. Commun. 2013, 4, 2167. (b) Roşca, D.-A.; Fernandez-Cestau, J.; Morris, J.; Wright, J. A.; Bochmann, M. Science Adv. 2015, 1, e1500761.

(9) Reviews: (a) Roşca, D.-A.; Wright, J. A.; Bochmann, M. Dalton Trans. 2015, 44, 20785-20807. (b) Kumar, R.; Nevado, C. Angew. Chem., Int. Ed. 2017, 56, 1994-2015.

(10) Pintus, A.; Bochmann, M. RSC Adv. 2018, 8, 2795-2803.

(11) (a) Joost, M.; Amgoune, A.; Bourissou, D. Angew. Chem., Int. Ed. 2015, 54, 15022-15045. (b) Rekhroukh, F.; Estevez, L.; MalletLadeira, S.; Miqueu, K.; Amgoune, A.; Bourissou, D. J. Am. Chem. Soc. 2016, 138, 11920-11929.

(12) (a) Comas-Vives, A.; González-Arellano, C.; Corma, A.; Iglesias, M.; Sánchez, F.; Ujaque, G. J. Am. Chem. Soc. 2006, 128, 4756-4765. (b) Casado, R.; Contel, M.; Laguna, M.; Romero, P.; Sanz, S. J. Am. Chem. Soc. 2003, 125, 11925-11935. (c) Lv, H.; Zhan, J.-H.; Cai, Y.-B.; Yu, Y.; Wang, B.; Zhang, J.-L. J. Am. Chem. Soc. 2012, 134, 16216-16227.

(13) (a) Klatt, G.; Xu, R.; Pernpointner, M.; Molinari, L.; Hung, T. Q.; Rominger, F.; Hashmi, A. S. K.; Köppel, H. Chem. - Eur. J. 2013, 19, 3954-3961. (b) Ung, G.; Bertrand, G. Angew. Chem., Int. Ed. 2013, 52, 11388-11391. (c) Reis, M. C.; López, C. S.; Kraka, E.; Cremer, D.; Faza, O. N. Inorg. Chem. 2016, 55, 8636-8645.

(14) Kumar, R.; Krieger, J.-P.; Gómez-Bengoa, E.; Fox, T.; Linden, A.; Nevado, C. Angew. Chem., Int. Ed. 2017, 56, 12862-12865.

(15) Kumar, R.; Linden, A.; Nevado, C. Angew. Chem., Int. Ed. 2015, 54, 14287-14290.

(16) David, B.; Monkowius, U.; Rust, J.; Lehmann, C. W.; Hyzak, L.; Mohr, F. Dalton Trans. 2014, 43, 11059-11066.

(17) Rocchigiani, L.; Fernandez-Cestau, J.; Budzelaar, P. H. M.; Bochmann, M. Chem. Commun. 2017, 53, 4358-4361.

(18) Reviews: (a) Bronner, C.; Wenger, O. S. Dalton Trans. 2011, 40, 12409-12420. (b) Wong, K. M.-C.; Chan, M. M.Y.; Yam, V. W.W. Adv. Mater. 2014, 26, 5558-5568.

(19) Complex 4 has been independently identified as one of the products in the reaction of $\mathbf{1}$ with an excess of L-selectride: C. Nevado, personal communication.

(20) (a) Hrobárik, P.; Hrobáriková, V.; Meier, F.; Repiský, M.; Komorovský, S.; Kaupp, M. J. Phys. Chem. A 2011, 115, 5654-5659. (b) Hrobárik, P.; Hrobáriková, V.; Greif, A.; Kaupp, M. Angew. Chem., Int. Ed. 2012, 51, 10884-10888. (c) Greif, A. H.; Hrobárik, P.; Hrobáriková, V.; Arbuznikov, A. V.; Autschbach, J.; Kaupp, M. Inorg. Chem. 2015, 54, 7199-7208.

(21) Greif, A. H.; Hrobárik, P.; Kaupp, M. Chem. - Eur. J. 2017, 23, 9790-9803.

(22) For SO-induced shielding/deshielding effects on ${ }^{13} \mathrm{C}$ shifts in gold complexes, see also: (a) Vícha, J.; Foroutan-Nejad, C.; Pawlak, T.; Munzarová, M.; Straka, M.; Marek, R. J. Chem. Theory Comput. 2015, 11, 1509-1517. (b) Novotný, J.; Vícha, J.; Bora, P. L.; Repiský, M.; Straka, M.; Komorovský, S.; Marek, R. J. Chem. Theory Comput. 2017, 13, 3586-3601.

(23) Roşca, D.-A.; Fernandez-Cestau, J.; Hughes, D. L.; Bochmann, M. Organometallics 2015, 34, 2098-2101.

(24) Nijamudheen, A.; Karmakar, S.; Datta, A. Chem. - Eur. J. 2014, $20,14650-14658$.

(25) Estes, D. P.; Norton, J. R.; Jockusch, S.; Wesley Sattler, W. J. Am. Chem. Soc. 2012, 134, 15512-15518.

(26) (a) Matsuura, K.; Muto, H. J. Phys. Chem. 1993, 97, 88428844. (b) Huang, M.-B.; Liu, Y. J. Phys. Chem. A 2001, 105, 923929.

(27) Clark, H. C.; Ferguson, G.; Goel, A. B.; Janzen, E. G.; Ruegger, H.; Siew, P. Y.; Wong, C. S. J. Am. Chem. Soc. 1986, 108, 6961-6972.

(28) Lancaster, S. J.; Rodriguez, A.; Lara-Sanchez, A.; Hannant, M. D.; Walker, D. A.; Hughes, D. L.; Bochmann, M. Organometallics 2002, 21, 451-453.
(29) (a) Currie, L.; Rocchigiani, L.; Hughes, D. L.; Bochmann, M. Dalton Trans. 2018, 47, 6333-6343. (b) Rocchigiani, L.; FernandezCestau, J.; Budzelaar, P. H. M.; Bochmann, M. Chem. - Eur. J. 2018, DOI: $10.1002 /$ chem.201801277.

(30) Rocchigiani, L.; Fernandez-Cestau, J.; Agonigi, G.; Chambrier, I.; Budzelaar, P. H. M.; Bochmann, M. Angew. Chem., Int. Ed. 2017, 56, 13861-13865.

(31) Note that ${ }^{1} \mathrm{H}$ hydride shifts computed at the two-component quasi-relativistic 2c-ZORA(SO)/PBE0-XC level, including the previously neglected terms from the exchange-correlation (XC) response kernel (see refs 20c and 32), agree very well with those obtained using the four-component fully relativistic (mDKS) method along with the same hybrid functional (cf. Table 1).

(32) (a) Autschbach, J. Mol. Phys. 2013, 111, 2544-2554. (b) Greif, A. H.; Hrobárik, P.; Autschbach, J.; Kaupp, M. Phys. Chem. Chem. Phys. 2016, 18, 30462-30474.

(33) In organic compounds ${ }^{1} \mathrm{H}$ NMR shifts are often considered to shift downfield (upfield) upon decrease (increase) of the atomic charge at the hydrogen atom.

(34) This is in line with the very recent predictions and detailed analysis of ${ }^{1} \mathrm{H}$ NMR shifts for hypothetical linear $\mathrm{HAu}{ }^{\mathrm{I}} \mathrm{L}$ hydrides, where the strong trans ligands were shown to destabilize the $\sigma(\mathrm{Au}-$ $\mathrm{H})$-type bonding MOs. ${ }^{21}$ These have a deshielding $\delta_{\text {SO }}$ contribution and compete with the shielding effect of $\mathrm{Au}\left(\mathrm{d}_{\pi}\right)$-based MOs. Once the $\sigma(\mathrm{Au}-\mathrm{H})$-type bonding $\mathrm{MO}$ has moved substantially above $\operatorname{Au}\left(\mathrm{d}_{\pi}\right)$-based MOs, mixing of these two types of scalar relativistic MOs into spinors becomes less favorable (the more so, the larger the energy gap between them) and results in an overall $\delta_{\text {so }}$ deshielding, and thus positive ${ }^{1} \mathrm{H}$ hydride shifts.

(35) The remarkable deviations are found for complexes with $\pi$ acceptor $\left(\mathrm{CO}\right.$ and $\left.\mathrm{PH}_{3}\right)$ ligands. This can be attributed to the more pronounced $\pi$-back-donation $(\mathrm{Au} \rightarrow \mathrm{L})$ in the electron-richer $\mathrm{Au}(\mathrm{I})$ hydrides as compared to $\mathrm{Au}(\mathrm{III})$ congeners.

(36) Despite the tendency of increasing negative charge at the hydride ligand upon increasing the $\sigma$-donor strength of the trans ligand, no reasonable correlation between atomic charges at the hydride ligand and ${ }^{1} \mathrm{H}$ NMR shifts for a wide set of ligands can be established.

(37) Useful correlations between ligand NMR shifts and M-L bond covalency, assessed by QTAIM delocalization indices, have been recently demonstrated also for actinide-chalcogen and organothorium complexes: (a) Smiles, D. E.; Wu, G.; Hrobárik, P.; Hayton, T. W. J. Am. Chem. Soc. 2016, 138, 814-825. (b) Smiles, D. E.; Wu, G.; Hrobárik, P.; Hayton, T. W. Organometallics 2017, 36, 45194524. In these multiple-bonded $\mathrm{f}^{0}$ systems, the ligand ${ }^{77} \mathrm{Se} /{ }^{125} \mathrm{Te} /{ }^{13} \mathrm{C}$ shifts are, however, dominated by paramagnetic shielding contribution and the opposite trend was observed, i.e., the ligand NMR shifts became more deshielded along with increasing $\mathrm{M}-\mathrm{L}$ bond covalency.

(38) Miller, W. T., Jr; Sun, K. K. J. Am. Chem. Soc. 1970, 92, 69856987.

(39) (a) Smith, D. A.; Roşca, D.-A.; Bochmann, M. Organometallics 2012, 31, 5998-6000. (b) Chambrier, I.; Rosca, D.-A.; FernandezCestau, J.; Hughes, D. L.; Budzelaar, P. H. M.; Bochmann, M. Organometallics 2017, 36, 1358-1364.

(40) Rosca, D.-A.; Smith, D. A.; Bochmann, M. Chem. Commun. 2012, 48, 7247-7249.

(41) Coles, S. J.; Gale, P. A. Chem. Sci. 2012, 3, 683-689. 